\title{
OS FATORES DETERMINANTES PARA A EFICIÊNCIA ECONÔMICA DOS PRODUTORES DE FRANGO DE CORTE: UMA ANÁLISE ESTOCÁSTICA
}

\section{JULCEMAR BRUNO ZILLI}

\begin{abstract}
Dissertação apresentada à Escola Superior de Agricultura "Luiz de Queiroz", Universidade de São Paulo, para obtenção do título de Mestre em Ciências, Área de Concentração: Economia Aplicada.
\end{abstract}

P I R A C I C A B A

Estado de São Paulo - Brasil

Novembro -2003 


\title{
OS FATORES DETERMINANTES PARA A EFICIÊNCIA ECONÔMICA DOS PRODUTORES DE FRANGO DE CORTE: UMA ANÁLISE ESTOCÁSTICA
}

\author{
JULCEMAR BRUNO ZILLI \\ Bacharel em Ciências Econômicas
}

Orientador: Prof. Dr. GERALDO SANT'ANA DE CAMARGO BARROS

\begin{abstract}
Dissertação apresentada à Escola Superior de Agricultura "Luiz de Queiroz", Universidade de São Paulo, para obtenção do título de Mestre em Ciências, Área de Concentração: Economia Aplicada.
\end{abstract}

P I R A C I C A B A

Estado de São Paulo - Brasil

Novembro -2003 
Dados Internacionais de Catalogação na Publicação (CIP)

DIVISĀO DE BIBLIOTECAE DOCUMENTAÇĀO - ESALQ/USP

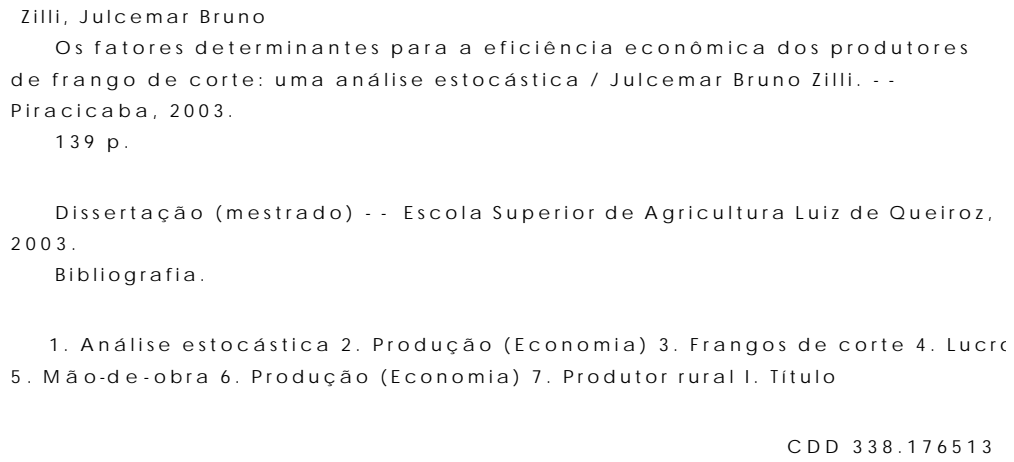




\section{Ofereço}

A TODA MINHA FAMÍUA,

ESPECIALMENTE AOS MEUS PAIS. SEM

VOCÊS, EU NÃO CONSEGUIRIA...

\section{Dedico}

A MINHA LINDA AIDA. COM SEU INCENTIVO, CONSEGUI ATINGIR ESTE OBJETIVO, ESPERO RETRIBUIR TODO O APOIO COM MUITO CARINHO E AMOR. 


\section{AGRADECIMENTOS}

Sou grato a DEUS, autor da VIDA, da ESPERANÇA e fonte de toda a SABEDORIA;

Aos meus pais, VALDIR E LOURDES, pela educação, pelo caráter e pela lição de vida dados com muito suor e trabalho, um exemplo de vida para mim. "AMO MUITO VOCÊS";

Aos meus irmãos, JERRIADRIANI E ELIZANDRO, pelo incentivo, pelos conselhos, pelas sugestões nos momentos difíceis e por serem meus IRMÃOS;

Às minhas cunhadas, LEONITA E BETIANE, pelo apoio e pela atenção despendidos para com minha família;

À minha sobrinha GABRIELA, que, mesmo sem entender o que acontece, enche nossa família de alegria e luz;

Ao Prof. Sérgio De Zen, à Prof ${ }^{a}$. Miriam R. P. Bacchi e à secretária Luciane Cavaggioni Scafi pela confiança, responsabilidade, pelo companheirismo e investimento realizados em mim;

Ao meu orientador Prof. Geraldo Sant'Ana de Camargo Barros, pela paciência, pelas contribuições e sugestões, norteando meus esforços para um fim proveitoso; 
À banca examinadora, pelos esforços despendidos, pela atenção e pelo carinho dedicados ao trabalho;

Ao Cepea, pelos auxílios financeiros e conhecimentos repassados durante todo o mestrado;

Aos professores e a todos os funcionários do Departamento de Economia, Administração e Sociologia da ESALQ, em especial a Maielli, Ligiana e Álvaro, pela maneira cordial e eficiente com que atenderam às minhas demandas;

À vila da pós-graduação da ESALQ, por aconchegar-me durante os primeiros anos do mestrado, o que desenvolveu um espírito de amizade e companheirismo entre vários colegas;

Aos colegas de mestrado, pelos incentivos e conhecimentos compartilhados para a concretização do curso;

Aos meus amigos de futebol (VILA TABAJARA FUTEBOL CLUBE), por proporcionarem momentos de lazer, descontração e integração com os demais. 
LISTA DE FIGURAS .................................................................................. viii

LISTA DE TABELAS ........................................................................ $\mathrm{x}$

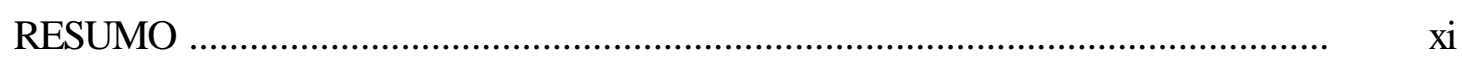

SUMMARY ............................................................................................. $\quad$ xiii

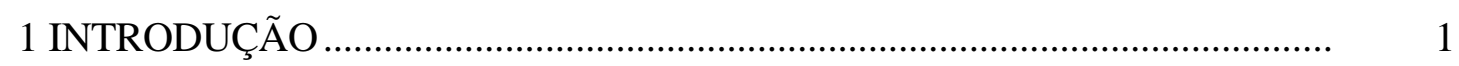

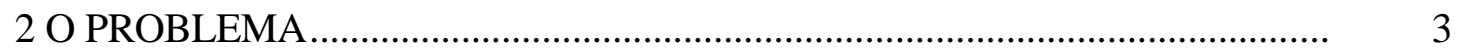

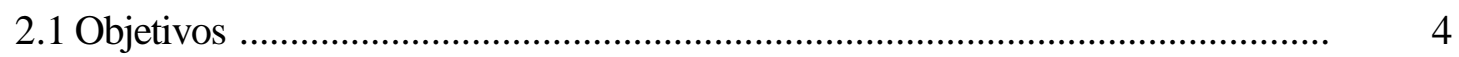

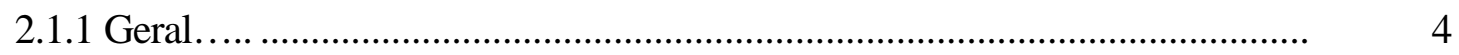

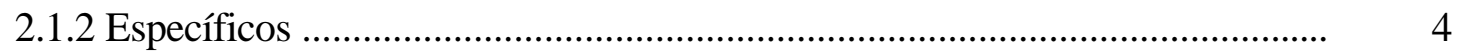

2.2 Contribuições relevantes ......................................................................... 5

2.3 Hipóteses .................................................................................................. 5

3 CONTEXTUALIZAÇÃO DOS PROBLEMAS E DOS OBJETIVOS ................. 8

$3.1 \mathrm{O}$ crescimento da produção ......................................................................... 10

3.1.1 Avanços tecnológicos................................................................................ 12

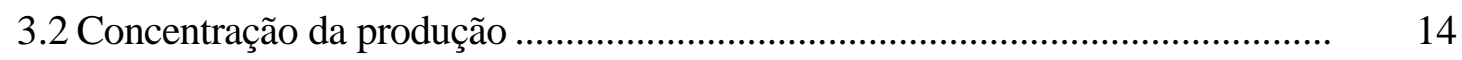

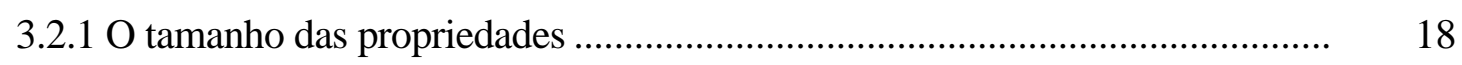

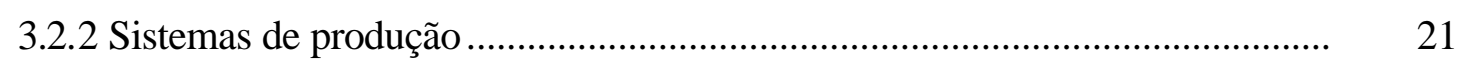

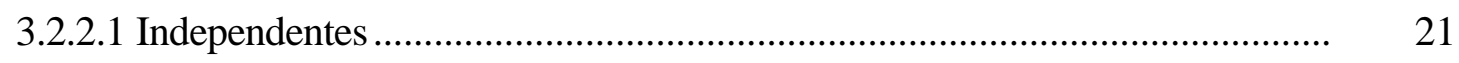

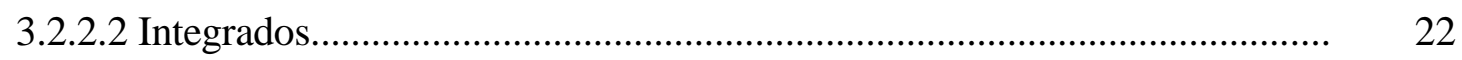

3.3 Características dos produtores de frango de corte amostrados nas regiões Sul e Centro-Oeste do Brasil ............................................................................... 25

3.4 Recursos financeiros ......................................................................... 29

3.5 A competitividade da cadeia avícola em nível dos produtores ......................... 33 
3.5.1 Fatores determinantes da competitividade ................................................. 34

3.6 Fatores ambientais relacionados à ineficiência ............................................... 35

3.6.1 Responsabilidade................................................................................... 36

3.6.2 Gastos com mitigação ambiental.................................................................... 39

4 MODELO ECONÔMICO............................................................................... 42

4.1 Medidas de eficiência ........................................................................................... 42

4.2 Conjunto de possibilidades de produção ............................................................. 43

4.3 Fronteiras de produção ………………………............................................... 44

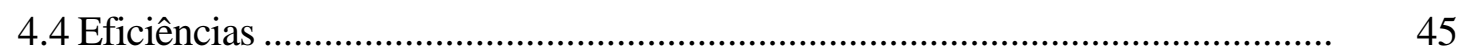

4.5 Técnicas de medidas de eficiência ................................................................... 48

4.6 Procedimentos econométricos para medir a eficiência ...................................... 49

4.7 Fronteiras de produção estocásticas ............................................................... 51

4.8 Forma estrutural da fronteira de lucro estocástica .......................................... $\quad 52$

4.9 Modelo empírico ……………....................................................................... 55

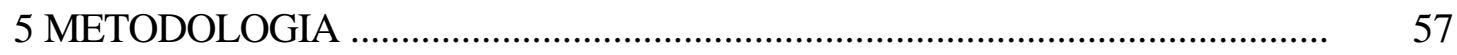

5.1 Variáveis explicativas ............................................................................... 57

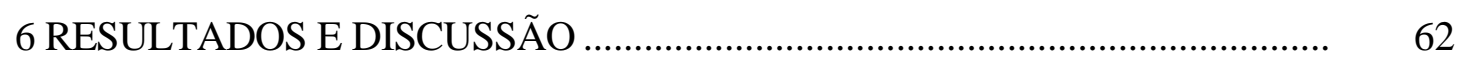

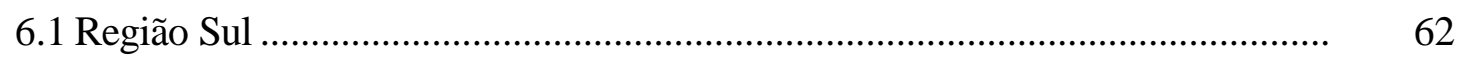

6.2 Região Centro-Oeste ................................................................................... 67

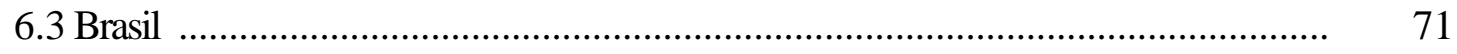

6.4 Comparações entre as regiões Sul e Centro-Oeste, e o Brasil ........................... 75

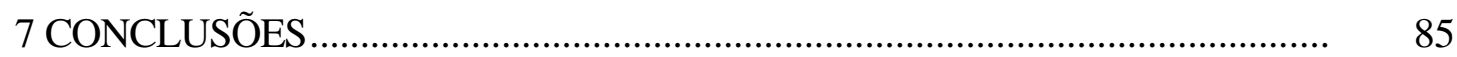

REFERÊNCIAS BIBLIOGRÁFICAS ............................................................ 89

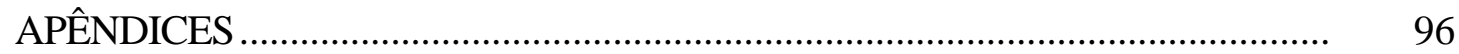


1 Crescimento da produção e do consumo brasileiros de carne de frango de 1986 a 2003 (Em toneladas).......................................... 1

2 Evolução do preço do frango de corte na praça de Campinas (preços reais) - Base Dez/2002.

3 Indicadores de produtividade do frango de corte nas regiões pesquisadas em 2002 .

4 Crescimento percentual da produção por região: 1988-2002 (Base 1988)...... 16

5 Percentual do Market Share dos maiores Estados de 1988 a 2001.................. 17

6 Número de propriedades rurais na região Sul do Brasil por tamanho da área.. 19

7 Número de propriedades rurais na região Centro-Oeste do Brasil por tamanho de área.

8 Fluxograma do funcionamento do sistema de integração vertical. ................... 24

9 Densidade de animais nas mesorregiões pesquisadas (cabeças/ha)................. 35

10 Preço médio do resíduo (cama de frango) nas mesorregiões pesquisadas em $\mathrm{R} \$ / \mathrm{t}$

11 Conjunto de possibilidades de produção........................................................ 44

12 Ponto de eficiência. ................................................................................ 47

13 Medidas de eficiência técnica e retornos à escala. .............................................. 48

14 Fronteira de lucro estocástica. ........................................................................ 53

15 Mapa das áreas selecionadas para pesquisa. ................................................. 58 
16 Distribuição de frequiência das medidas de eficiência dos produtores das

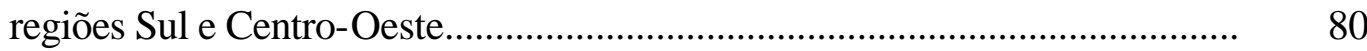

17 Níveis de eficiência econômica dos produtores da região Sul por tamanho da produção $(\%)$............................................................................................

18 Níveis de eficiência econômica dos produtores da região Centro-Oeste por tamanho da produção $(\%)$..................................................................................

19 Níveis de eficiência econômica dos produtores amostrados no Brasil por tamanho da produção $(\%)$. 
1 Percentual dos produtores amostrados por estratos de tamanho..................... 26

2 Percentual de produtores da amostra por área de propriedade......................... 27

3 Percentual de produtores da amostra dependentes da renda avícola por Estado........................................................................................ 28

$4 \quad$ Número de produtores da amostra que utilizam crédito rural. ........................ 30

$5 \quad$ Número de produtores da amostra por fontes de recursos financeiros. ........... 31

$6 \quad$ Número de produtores da amostra por destino de crédito rural. ...................... 32

7 Análise descritiva dos dados da fronteira de lucro para a região Sul............... $\quad 60$

8 Análise descritiva dos dados da fronteira de lucro para a região Centro-

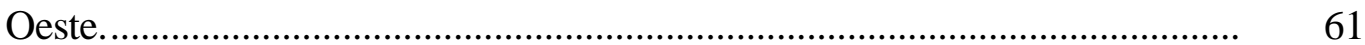

9 Coeficientes obtidos para a fronteira de lucro da região Sul............................ 64

10 Coeficientes obtidos para os efeitos da ineficiência econômica da região Sul. 66

11 Coeficientes obtidos para a fronteira de lucro da região Centro-Oeste.

12 Coeficientes obtidos para os efeitos da ineficiência econômica da região Centro-Oeste

13 Coeficientes obtidos para a fronteira de lucro do Brasil.

14 Coeficientes obtidos para os efeitos da ineficiência econômica do Brasil.......

15 Comparativo dos coeficientes estimados para a fronteira de lucro estocástica para as regiões Sul e Centro-Oeste, e para o Brasil.

16 Efeitos da ineficiência sobre as diferentes regiões analisadas. 


\title{
OS FATORES DETERMINANTES PARA A EFICIÊNCIA ECONÔMICA DOS PRODUTORES DE FRANGO DE CORTE: UMA ANÁLISE ESTOCÁSTICA
}

\author{
Autor: JULCEMAR BRUNO ZILLI \\ Orientador: Prof. Dr. GERALDO SANT'ANA DE CAMARGO BARROS
}

\section{RESUMO}

A produção de frango de corte tem impressionado pelo dinamismo e pela competência conquistada nas últimas décadas, destacando-se o Brasil como o segundo maior produtor dessa proteína animal. $\mathrm{O}$ ganho de produtividade, associado à coordenação da cadeia avícola, colocou o País como um dos mais eficientes produtores. Entretanto, a significativa especialização da atividade tende a excluir do processo produtivo os pequenos avicultores e os produtores menos eficientes. Assim, o estudo buscou medir a eficiência econômica dos produtores de frango de corte das regiões Sul e Centro-Oeste do Brasil, identificando quais fatores influenciam essa medida de desempenho. Para isso, usou-se uma função fronteira de lucro estocástica em um estágio (modelo 2) em que os coeficientes da fronteira e os efeitos da ineficiência são obtidos simultaneamente, assumindo que os termos de erro não são identicamente distribuídos. Concluiu-se que para a região Sul, o preço da mão-de-obra contratada interfere significativamente na lucratividade das unidades produtivas, o que seria um dos fatores associados ao maior uso do trabalho familiar no desenvolvimento das atividades. Além disso, os resultados sugerem a presença de uma melhor utilização das áreas 
ocupadas com a produção avícola. Os efeitos da ineficiência são sentidos pincipalmente no baixo nível de educação dos que tomam as decisões e nos índices elevados de conversão alimentar. Já no Centro-Oeste, os coeficientes indicaram que o maior uso de mão-de-obra familiar poderia elevar a lucratividade dos produtores. Pelo fato de ser uma região relativamente nova e possuir condições favoráveis ao investimento em capital e tecnologia, estaria indicando um maior lucro na atividade. Não se identificou ganho de escala por meio do modelo estocástico. Embora não se observa uma tendência contínua associada à escala de eficiência, no Centro-Oeste parece existirem ganhos de eficiência relevante nos estratos de médio e alto escala de produção para os padrões regionais. 


\title{
OS FATORES DETERMINANTES PARA A EFICIÊNCIA ECONÔMICA DOS PRODUTORES DE FRANGO DE CORTE: UMA ANÁLISE ESTOCÁSTICA
}

\author{
Author: JULCEMAR BRUNO ZILLI
}

Adviser: Prof. Dr. GERALDO SANT’ANA DE CAMARGO BARROS

\section{SUMMARY}

The dynamism and ability acquired through the last decade by the broiler production is very impressive. The productivity rate gain associated to the good management of poultry chain in Brazil led the country to be the second biggest producer of this animal's protein. However, the significant specialization of this activity tend to exclude the smaller producers and those who are lesser efficient in the productive process. In view of that, this study intends to precise the economic efficiency of the broiler producers in the Southerner and Center-Southerner regions of Brazil. For that, the main factors that influence the economic efficiency were identified. To reach those results, it was considered the stochastic profit function in a stage (model 2) where the coefficients of the frontier and the inefficiency effects are obtained simultaneously, since the terms of error are not identical distributing. It was possible to conclude that in the Southerner region of Brazil, the contracted labor force influence significantly the profitability of the productive farms. That's one of the factors that explain the great use of the familiar labor force in that region. Moreover, the results pointed a better utilization of the broiler producing areas in Brazil. The effects of the inefficiency are present mainly in the producers and players with low educational level, and also in the 
high food conversion ratio. In the Center-Westerner of Brazil, the coefficients pointed that the better use of the familiar manpower could raise the probability of the producers. For been a new region that present positive conditions for the investments in capital and technology, it also obtained a larger profit with the activity. It was not identified gains by the stochastic model. None successively trend associated to the efficiency scale were pointed in the Center-Westerner of Brazil. Even so, the region shows efficiency gains in the middle and high scales of production in regional terms. 


\section{INTRODUÇÃO}

A avicultura de corte tem impressionado pela competência e pelo dinamismo alcançado nas últimas décadas, proporcionando ao Brasil uma posição de destaque entre os maiores produtores mundiais de carne de frango. Isso se deve muito aos ganhos de produtividade obtidos pelo setor, favorecidos pelos avanços tecnológicos nas áreas de genética, nutrição, equipamentos, manejo e sistema de produção.

A implantação de um sistema de produção integrando pequenos produtores rurais e agroindústria é citada por Ferreira et al. (2000) como uma das razões que influenciaram o desenvolvimento da atividade avícola, permitindo ganhos de produtividade e de coordenação que redundaram no aumento da competitividade. A melhoria na coordenação da cadeia produtiva permite que ela reaja mais rapidamente às mudanças de hábitos de consumo e aumente a eficiência das atividades dos seus agentes individualmente ou da cadeia como um todo.

Conseqüentemente, a forte especialização da atividade, associada à dificuldade de obtenção de financiamentos, tem imposto algumas barreiras aos pequenos produtores. A disseminação de um modelo de integração vertical centrado preferencialmente no médio e/ou grande produtor teria impacto social significativo, visto que o segmento avícola buscaria excluir do processo produtivo os avicultores, principalmente os menos capitalizados e os menos eficientes (Fernandes Filho \& Queiroz, 2001).

Desta forma, o controle no uso dos principais insumos da produção e de seus preços é importante para a avicultura, já que a eficiência implica a necessidade de obter mais produtos com as mesmas quantidades de insumos e/ou utiliza-los nas quantidades ótimas com os menores preços possíveis dado à tecnologia de produção empregada na propriedade. Ou seja, deve-se reduzir os custos de produção e aumentar a produtividade 
para melhorar os índices de eficiência e garantir a sobrevivência dos produtores na zona rural.

Nesse cenário, este trabalho busca analisar quais são os fatores sob controle da unidade produtora que podem influenciar a eficiência econômica ${ }^{1}$ dos produtores de frango de corte nas regiões Sul - PR, SC e RS - e Centro-Oeste - MS, MT e GO -, para onde ocorre uma tendência de deslocamento das plantas industriais.

Foram utilizadas informações captadas junto aos produtores de frango de corte por meio de uma pesquisa desenvolvida em 2002/2003 pelo Centro de Estudos Avançados em Economia Aplicada (Cepea) em parceria com o Órgão das Nações Unidas para a Agricultura e Alimentação (FAO/ONU) e que englobou os setores de suíno, leite, frango e ovos.

O trabalho está estruturado em 8 capítulos. O Capítulo 2 trata da relevância dos fatores produtivos relacionados à eficiência econômica e descreve os objetivos gerais e específicos a serem atingidos com o estudo. No 3, realiza-se uma contextualização dos problemas e dos objetivos propostos. No Capítulo 4, explicita-se o modelo econômico e os conceitos necessários para a compreensão dos índices de eficiência econômica. O 5 trata dos dados e métodos que fornecerão os indicadores da eficiência dos produtores pesquisados. Os Capítulos 6 e 7 apresentam os resultados, as discussões e conclusões sobre quais são os efeitos das variáveis na eficiência dos produtores de frango de corte das regiões Sul e Centro-Oeste.

\footnotetext{
${ }^{1}$ Segundo Saheli e Macedo (1998), a eficiência econômica é um conceito que se refere à capacidade do agente produzir o maior nível de produto com o menor custo possível, o que significa maximizar a produção, dado o nível de insumos - eficiência técnica -, e minimizar os custos, dado o nível de produção - eficiência alocativa.
} 


\section{O PROBLEMA}

A evolução brasileira na avicultura de corte, sob os diferentes aspectos em que se a análise, fornece uma série de dados e informações que apontam para um grande dinamismo do setor. Estudo do Banco Mundial (Henry \& Rothwell, 1995) apontou a competência da avicultura brasileira como sendo a mais eficiente do mundo e com o menor custo de produção, o que, teoricamente, seria um indicador de que as exportações brasileiras dessa proteína animal teriam maior participação no mercado mundial. Segundo a Associação Brasileira dos Produtores e Exportadores de Carne de Frango (Abef, 2003), em 2002, o Brasil exportou aproximadamente 1,6 milhão de toneladas de carne, deixando o País como o segundo maior exportador da proteína animal.

Vários fatores contribuíram significativamente para que fossem alcançados os excelentes ganhos de produtividade. Entre eles, pode-se citar as inovações tecnológicas na área de genética, da alimentação, de equipamentos, de manejo e o sistema de produção verticalmente integrado.

A verticalização das atividades foi uma maneira encontrada pela agroindústria para garantir um fornecimento estável de frango de corte. O produtor foi beneficiado pela redução do capital de giro necessário para a produção e pelo baixo risco da atividade. Entretanto, foi prejudicado pela falta de poder na tomada de decisão e pelas baixas remunerações. $\mathrm{O}$ modelo de produção de carne de frango centrado na integração pequeno produtor-agroindústria integradora predomina na avicultura de corte brasileira até hoje e, portanto, contribui para o elevado crescimento da produção no Brasil.

Normalmente, os produtores são considerados o elo mais fraco da cadeia produtiva e, dessa forma, precisam de ferramentas que os auxiliem na obtenção de melhor rentabilidade e eficiência na atividade. 
As medidas de eficiência econômica de uma unidade produtiva podem auxiliar na tomada de decisão, contribuindo para aumentar a produção racionalmente.

Segundo Lovell (1993), citado por Tupy (1996), tanto a eficiência quanto a produtividade são indicadores de sucesso, medidas de desempenho por intermédio das quais os produtores são avaliados. Somente medindo a eficiência e a produtividade, e separando os efeitos do ambiente de produção, pode-se explorar hipóteses relacionadas às fontes de diferenças entre eficiência e produtividade.

Dessa maneira, operar com eficiência econômica é fundamental para a sobrevivência das unidades produtivas. Assim, torna-se imprescindível controlar a eficiência econômica, uma vez que os produtores menos eficientes podem ser excluídos da produção. A identificação dessas fontes de eficiência é essencial para a instituição de políticas públicas e privadas que possam motivar ainda mais a produção avícola nas regiões brasileiras.

\subsection{Objetivos}

\subsubsection{Geral}

O objetivo essencial deste trabalho é identificar quais são os fatores, sob controle das unidades produtivas ou dos órgãos públicos, que estão influenciando a eficiência econômica dos produtores de frango de corte.

\subsubsection{Específicos}

$\Rightarrow$ Caracterizar o sistema brasileiro de produção de frango de corte nas regiões pesquisadas diante das informações obtidas;

$\Rightarrow$ Estimar as medidas de eficiência econômica dos produtores;

$\Rightarrow$ Avaliar os efeitos das variáveis relacionadas à ineficiência dos produtores de frango nas unidades rurais. 


\subsection{Contribuições relevantes}

O estudo proposto contribuirá para a conscientização dos produtores e das agroindústrias sobre a relevância que o controle da produção exerce sobre a eficiência econômica dos criadores das regiões Sul e Centro-Oeste.

Para a sociedade, contribui-se demonstrando a real situação dos produtores de frango de corte perante algumas questões socioeconômicas, as quais podem influenciar a eficiência deles.

\subsection{Hipóteses}

Diante dos conceitos descritos, levantam-se algumas hipóteses sobre os fatores que interferem na eficiência econômica dos produtores de frango de corte nas propriedades das regiões Sul e Centro-Oeste.

$\checkmark$ A conversão alimentar dos produtores da região Centro-Oeste é maior do que á encontrada na região Sul, com isso, a eficiência será menor.

$\checkmark$ Os gastos com mitigação ambiental proporcionam menor eficiência para as propriedades localizadas na região Sul, o que não deve acontecer com as do CentroOeste.

$\checkmark$ A concentração animal na fazenda estará influenciando negativamente a eficiência na região Sul devido às pequenas áreas das propriedades. Para a região CentroOeste, espera-se não haver problemas relacionados a essa variável.

$\checkmark$ Os produtores de frango de corte com maiores escalas de produção, principalmente os localizados na região Centro-Oeste, terão maiores índices de eficiência econômica.

$\checkmark$ A experiência na atividade pode favorecer a região Sul, ou seja, uma variável que aumenta a eficiência dessa região.

$\checkmark$ A escolaridade dos produtores influenciará positivamente a eficiência da produção, principalmente na região Centro-Oeste, onde os índices de escolaridades encontrados 
são maiores.

$\checkmark$ Os produtores mais jovens são mais eficientes em ambas as regiões.

$\checkmark$ Os produtores que possuem atividades fora da propriedade apresentam maiores eficiências do que os demais.

$\checkmark$ Os produtores que moram na propriedade possuem maiores índices de eficiência.

Diante disso, espera-se que, em diversos casos, ocorra uma indicação de relacionamento negativo entre progresso técnico e ganho de eficiência na atividade avícola brasileira. A redução nos índices de conversão alimentar é uma medida do progresso técnico observado nos últimos tempos. Desse modo, haverá um aumento nas medidas de eficiência econômica.

$\mathrm{O}$ gasto com mitigação ambiental na região Sul deve ser maior, dado à maior concentração de animais e à proximidade das propriedades a zona urbana.

A elevada concentração de frango de corte na região Sul, devido às pequenas áreas de terra nas suas propriedades, leva a acreditar que os produtores sentem o efeito dessa variável na eficiência econômica.

A presença de economias de escala junto à atividade avícola foi um dos fatores que viabilizaram a implantação da avicultura na região Centro-Oeste. Assim, os produtores dessa região devem obter efeitos negativos na ineficiência, ou seja, as grandes escalas de produção serão menos ineficientes.

Entretanto, a experiência da região Sul na produção de frango de corte é um fator que proporciona maior eficiência aos produtores. Como o desenvolvimento da atividade avícola aconteceu, basicamente, na região Sul, o nível de conhecimento adquirido pelos avicultores deverá fornecer indícios de eficiência econômica.

Os maiores níveis de escolaridade são importantes ferramentas para a continuidade de uma atividade que cada vez mais preza pela profissionalização dos agentes envolvidos na produção. Diante disso, os produtores com melhores graus de educação possuem melhores índices de eficiência. Nesse sentido, o Centro-Oeste do Brasil não terá maiores problemas diante dos efeitos da escolaridade, pois é uma região com produtores de nível educacional maior do que os verificados na região Sul.

Os tomadores de decisão mais jovens conseguem absorver com melhor eficiência 
as mudanças impostas pela agroindústria no sistema produtivo. Assim, o fato de os produtores serem mais jovens deverá proporcionar uma elevação da eficiência econômica.

Produtores com atividades fora da propriedade, por possuírem maior contato com os sistemas administrativos ou organizacionais difundidos pela sociedade, devem obter efeitos de redução nos índices de ineficiência. O profissionalismo empregado na atividade avícola na região Centro-Oeste indicará ausência de efeitos prejudiciais à eficiência.

Entretanto, aqueles produtores que moram na propriedade conseguem coordenar melhor a atividade avícola, pois estão mais próximos dos seus funcionários ou mesmo dos seus familiares. Nesse sentido, o fato de residirem nas propriedades deve ser um fator relevante para o aumento da eficiência econômica dos produtores de frango de corte. 


\section{CONTEXTUALIZAÇÃO DOS PROBLEMAS E DOS OBJETIVOS}

O Brasil é um país de grandes extensões territoriais e diferentes condições climáticas, onde o setor agropecuário possui papel relevante. Mesmo diante das deficiências existentes nas medidas governamentais sobre a política de financiamento e de preços destinada a esse setor, a atividade agropecuária tem movimentado milhões de reais em recursos, gerando milhares de empregos e transformando algumas regiões do país em pólos econômicos de riquezas.

Nos últimos vinte anos, o setor agropecuário brasileiro, principalmente a avicultura, passou por importantes mudanças estruturais, destacando-se o desenvolvimento do setor industrial, o controle de qualidade total, a evolução do mercado consumidor e o aumento da competitividade nos mercados nacional e internacional.

Esse processo de transição tem exigido um maior esforço dos participantes do setor, sobretudo dos avicultores, para o controle das técnicas gerenciais, pressionados pela necessidade de melhorar a eficiência técnica, alocativa e econômica por meio da administração e do controle das atividades desenvolvidas na propriedade rural.

Porém, a falta de auxílio e incentivo tem posto em risco muitos produtores rurais, visto que não conseguem manter um controle gerencial adequado das suas atividades. Existe a necessidade de transformar a propriedade em empresa rural, garantindo assim, a permanência e sobrevivência deles na zona rural.

Souza et al. (1992) destacam que, no setor agropecuário, há várias conceituações possíveis de empresa rural. A empresa rural é considerada como uma unidade de produção com elevado nível de capital de exploração e alto grau de comercialização, tendo como objetivos técnicos a sobrevivência, o crescimento e a busca de resultados 
positivos.

A falta de controle, segundo Grateron (1996), limita a capacidade de tomada de decisões do produtor rural ao comparar o que foi planejado com o realizado e identificar as ações necessárias para uma imediata ação corretiva.

Além disso, a avicultura demonstra uma forte tendência à especialização da produção que, aliada à instabilidade da economia e à necessidade de obtenção de renda em prazos mais curtos, tem imposto aos produtores a necessidade de investirem no melhoramento das condições das instalações, de acordo com as exigências das empresas integradoras. Assim, o segmento avícola exclui do processo produtivo os avicultores, principalmente os mais descapitalizados e os menos eficientes.

Os recursos financeiros necessários para a realização dos investimentos precisam ser fornecidos por instituições financiadoras, que exigem dos produtores a garantia do capital emprestado, e, nesses casos, o tamanho da propriedade ou a burocracia dos processos tornam-se limitantes.

Adicionalmente, a baixa eficiência das unidades produtoras frente à utilização dos insumos e dos preços prejudicará a rentabilidade da atividade avícola. O fato é que o mercado não aceita produtor ineficiente por muito tempo e, assim, penaliza-os com a eliminação do processo produtivo.

Segundo Fernandes Filho \& Queiroz (2001), a disseminação do modelo integração baseado no médio/grande produtor teria impacto social significativo. Um seria provocado pela exclusão do pequeno produtor da condição de integrado se mantidas as condições institucionais referentes às exigências para concessão de empréstimos bancários.

A concessão dos empréstimos bancários está sob controle de agentes externos a atividade produtiva dos agricultores. Fornecer auxílios para a resolução desse problema burocrático é tarefa dos órgãos públicos.

Já o uso dos fatores de produção sobre controle do produtor rural pode ser responsável pela baixa eficiência na atividade. Assim, a identificação dos efeitos que interferem na eficiência econômica da avicultura na propriedade será o primeiro passo na busca da garantia de sobrevivência dos produtores de frango de corte, especialmente 
dos pequenos.

\section{$3.1 O$ crescimento da produção}

A produção de carnes figura entre os setores com maior dinamismo na economia brasileira, passando a ser uma atividade altamente especializada. Nesse cenário, a produção de frango de corte destaca-se pelo dinamismo evidenciado pelas mudanças nas características dos produtos, pela inserção no mercado internacional, pelos avanços tecnológicos e pelas alterações das escalas de produção. Nos últimos anos a produção brasileira tem-se caracterizado como uma das maiores do mundo (Talamini et al., 1998).

O crescimento do setor, segundo Wilkinson (1995), ocorreu a partir da alteração do comportamento do mercado doméstico da carne de frango, impulsionado pelo rápido declínio do preço relativo frente às outras carnes.

A Figura 1 mostra os gráficos da evolução da produção e do consumo obtidos pela cadeia avícola nos últimos 18 anos. Para o ano de 2002, de acordo com dados da Abef (2003), a produção brasileira de carne de frango atingiu 7,5 milhões de toneladas contra os 1,62 milhão produzidos em 1986. Assim, pode-se observar que o crescimento obtido pelo setor na produção atingiu 365\% de 1986 a 2002. O destaque está em 1995, ano no qual a avicultura obteve seu maior crescimento produtivo, atingindo $16 \%$ frente a 1994. Os demais anos apresentaram aumentos acima de 6\% a.a., com exceção de 1996 e 2003, que tiveram taxas de crescimento inferiores a 0,5\% e 5\%, respectivamente.

O consumo interno dessa proteína seguiu a evolução da produção. O crescimento no período de 1986 a 2002 chegou a 325\%, com destaque para 1995, que obteve uma elevação superior a $20 \%$ a.a. Entretanto, o ano de 1996 registrou um declínio de $4 \%$ nos índices de consumo da população brasileira. Os demais anos indicaram evolução superior a $7 \%$ a.a., exceto a previsão para 2003, que está demonstrando um acréscimo inferior a $4 \%$.

Uma das hipóteses levantadas sobre o aumento da procura por carne de frango provém da queda relativa do preço dessa carne frente às outras. Pode-se observar na Figura 2 que os preços, medidos em termos reais (deflacionados), apresentaram uma 
queda considerável nos últimos 12 anos. Para visualizar os períodos de declínio, pode-se dividir a série em dois segmentos: a primeira vai até 1994, e a segunda, até os dias atuais.

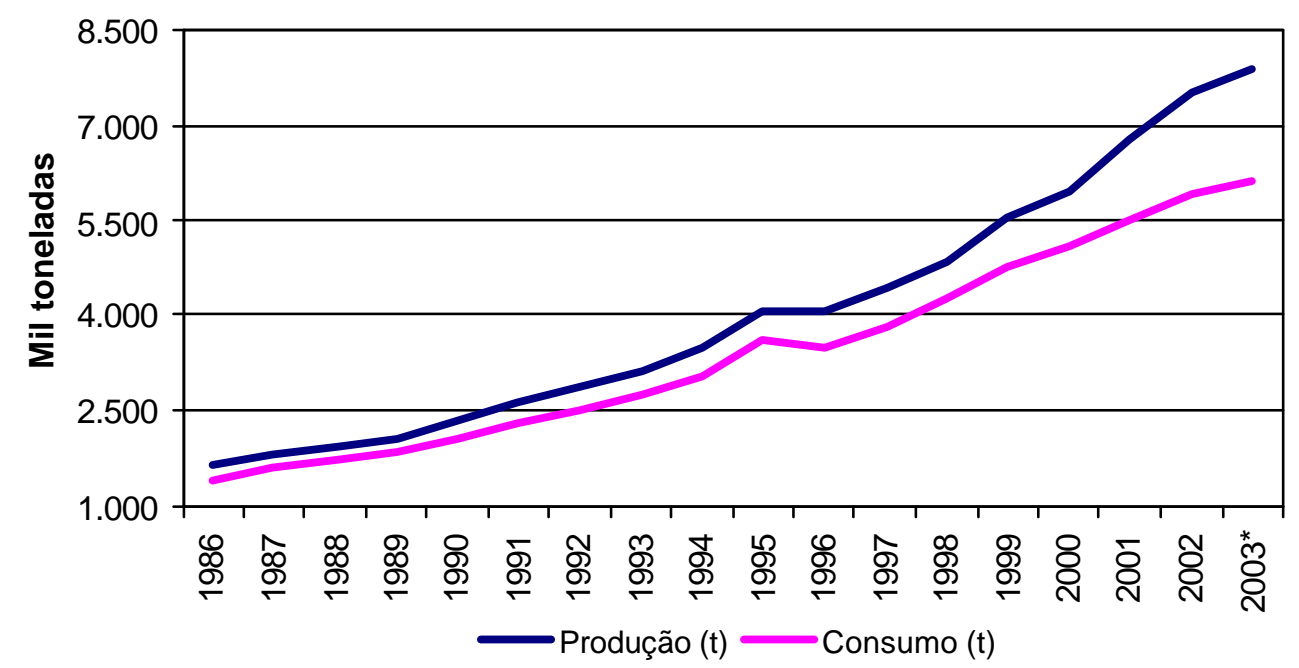

Figura 1 - Crescimento da produção e do consumo brasileiros de carne de frango de 1986 a 2003 (Em toneladas).

Fonte: Abef (2003)

*Previsão

Primeiramente, predominavam as ações das forças de mercado sobre os preços dos produtos, fazendo com que eles apresentassem acentuadas oscilações no decorrer de um ano. Ao mesmo tempo houve uma redução acumulada do preço real do frango em cerca de 67\% em relação ao preço real de 1989.

A partir de 1994, com a implantação do Real, os preços da carne de frango mantiveram-se mais estáveis, dado que a carne de frango foi considerada uma das âncoras do Plano. As outras oscilações nos preços pós-Plano Real são devidas, principalmente, a problemas com custos da matéria-prima, como milho e soja. Além 
disso, a estabilidade e a valorização cambial também contribuíram para a evolução observada.

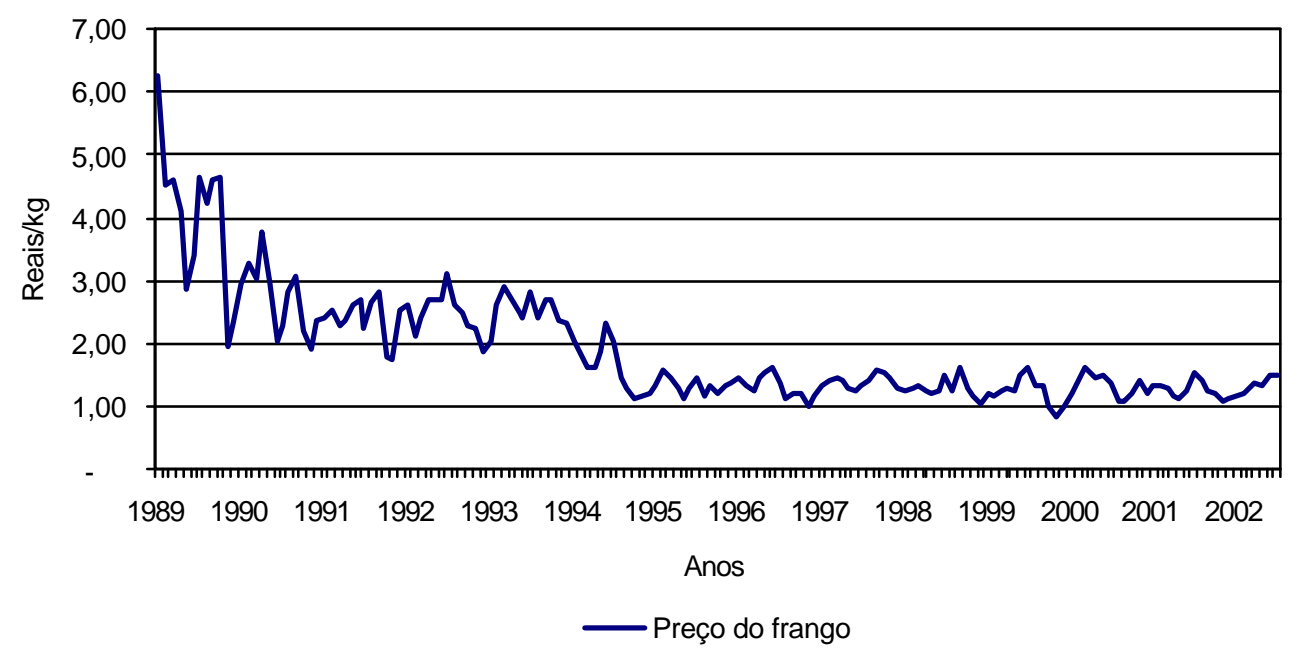

Figura 2 - Evolução do preço do frango de corte na praça de Campinas (preços reais) Base Dez/2002.

Fonte: Fundação Getúlio Vargas (FGV) (2003)

\subsubsection{Avanços tecnológicos}

Conforme Schorr (1999), Camargo (1999) e Carmo (2001), o crescimento da produção é atribuído aos elevados níveis tecnológicos alcançados pela avicultura nacional em decorrência do incremento de várias áreas correlatas.

O desenvolvimento da genética, mediante a obtenção de híbridos, proporcionou o aperfeiçoamento de várias linhagens de aves, transformando-se em verdadeiros nichos de mercado, bastando apenas desenvolver produtos distintos e disponibilizá-los em diferentes formas para serem apreciados pelos consumidores.

O surgimento de inúmeras pesquisas na área sanitária, sobretudo Newcastle, Gumboro, proporcionou um maior controle dos plantéis de frango de corte, obtendo resultados excelentes nos seus índices zootécnicos.

$\mathrm{O}$ aparecimento de novas fórmulas nutricionais influenciou o desenvolvimento da atividade, fornecendo ótimos resultados nos índices de conversão na atividade avícola 
brasileira, que são responsáveis por uma redução significativa dos custos de produção, visto que, no custo da ração, o milho é responsável por $40 \%$ a $45 \%$, e o farelo de soja contribui com 25\% a 30\% (Lazzarini et al., 1996).

A conversão alimentar - quantidade de ração necessária para obter $1 \mathrm{~kg}$ de frango vivo -, utilizada como um indicador de produtividade, demonstra os ganhos de produtividade obtidos na produção do frango de corte. Em 1930, segundo Aves e Ovos (1995), a conversão alimentar estava próxima aos 3,500 kg e o frango alcançava um peso médio de $1,500 \mathrm{~kg}$ em torno de 105 dias. Nos dias atuais, conforme dados da pesquisa de Barros \& Zen², a conversão é de aproximadamente $1,850 \mathrm{~kg}$ de ração para cada $1 \mathrm{~kg}$ de frango vivo, com o frango alcançando um peso médio de 2,240 kg em 42 dias de vida.

Pode-se avaliar no gráfico da Figura 3 dois dos principais indicadores de produtividade dos dias atuais: o peso médio de abate e a conversão alimentar dos frangos vivos.

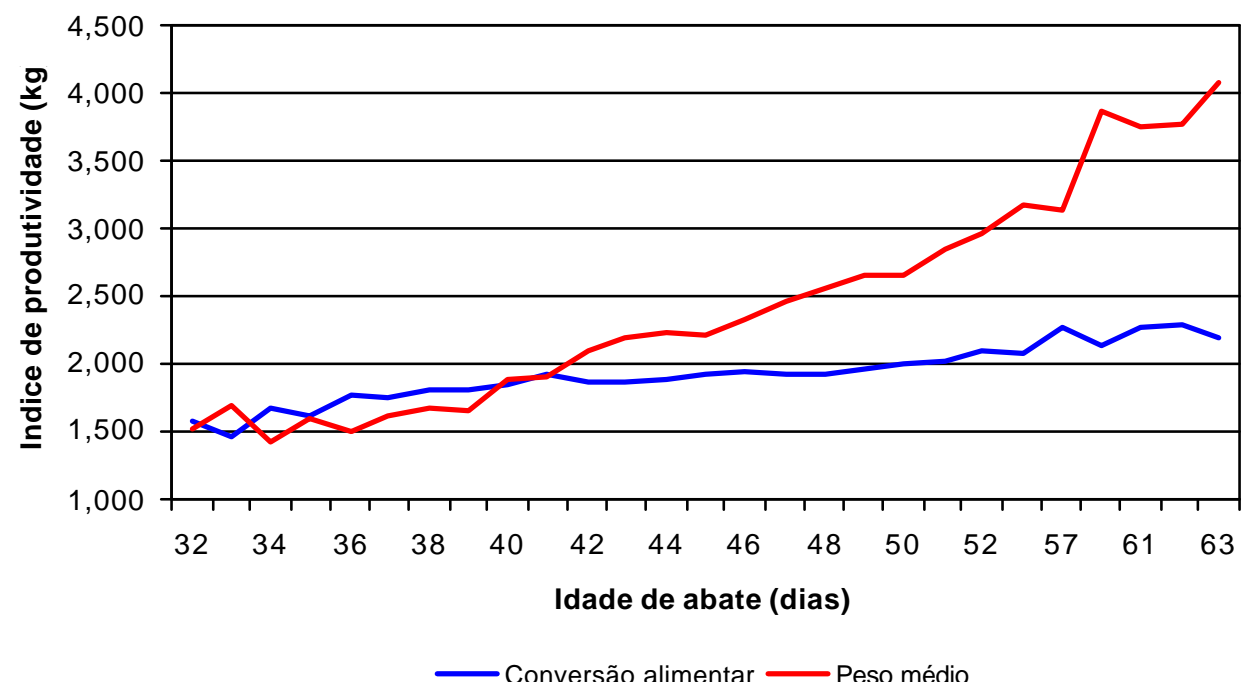

Figura 3 - Indicadores de produtividade do frango de corte nas regiões pesquisadas em 2002.

Fonte: Barros \& Zen, op. cit., p.13.

${ }^{2}$ BARROS, G.S. de C.; ZEN, S.D. (ESALQ. Centro de Estudos Avançados em Economia Aplicada CEPEA, Piracicaba). Comunicação pessoal, 2003. 
A melhora dos níveis de conversão alimentar propiciou significativas diminuições nos custos de produção de frango de corte, comprovadas por Almeida et al. (2000) em seu trabalho sobre estrutura, conduta e desempenho da cadeia avícola brasileira. Os avanços tecnológicos auxiliaram o aumento da produtividade e a queda dos preços da carne de frango, devido aos custos de produção mais baixos.

Além dessas inovações, deve-se considerar o uso de instalações mais apropriadas - em certas regiões padronizadas - e o sistema de produção integrada à agroindústria.

\subsection{Concentração da produção}

O crescimento na produção, combinado com uma maior demanda, mais pessoas e menor espaço, está levando o setor animal a uma transformação global dos seus processos produtivos (Steinfeld et al., 2002).

Ap Dewi et al. (1994), em seu trabalho sobre intensificação da produção animal, concluíram que o aumento da demanda fornece incentivos para o crescimento de toda a oferta existente, indiferente de níveis correntes, junto com uma ampliação da demanda de terra. Entretanto, o desafio é obter elevados níveis de eficiência evitando a concentração de atividades. Assim, além de acreditar que no futuro próximo já estejam difundidas técnicas que amenizem os problemas em regiões de elevada concentração produtiva, a própria restrição de espaço físico para a expansão da atividade torna-se uma barreira à expansão da produção.

A menor pressão exercida sobre o meio ambiente e a maior disponibilidade de grãos está influenciando o surgimento de uma nova fronteira de produção avícola na região Centro-Oeste do Brasil. Segundo Talamini et al. (1998), no curto prazo, os problemas ambientais associados à produção de frango de corte e suínos tendem a ser resolvidos por investimentos em tecnologia e manejo dos dejetos ou pelo deslocamento de parte da produção para áreas que apresentem menor potencial poluidor e menor densidade populacional.

Os Estados que possuem matéria-prima adequada e em abundância, clima e proximidades a mercados consumidores estão aumentando suas participações na 
produção. Esse foi o resultado a que Santana (1999) e Carvalho Junior \& Gelinski Neto (1998) chegaram, ou seja, que a concentração da produção realmente está diminuindo, embora algumas dificuldades estejam sendo encontradas, como, por exemplo, a mão-deobra inadequada. Essa tem sido a dificuldade de diversos empreendimentos no Brasil, embora seja importante destacar a revelação de diversos empresários: “Após treinamento adequado, a mão-de-obra no Brasil, em geral, torna-se muito produtiva e criativa na busca por soluções para os problemas encontrados no desenvolvimento de suas atividades".

Os dados da participação dos Estados na produção brasileira de 1988 a 2002 na Figura 4 demonstram um crescimento constante nos cinco primeiros anos, em todas as regiões brasileiras. Porém, a partir de 1993, somente as regiões Sul, Centro-Oeste e Sudeste conseguiram manter seus crescimentos constantes. Nas regiões, houve oscilações significativas que podem ser explicadas pela maior profissionalização das agroindústrias e de seus produtores, que eliminaram alguns agentes da atividade por não serem competitivos.

As regiões Centro-Oeste (792\%), Sul (375\%) e Sudeste (231\%) são as que conseguiram taxas crescentes na produção brasileira desde 1988 (Figura 4), preservando suas proporcionalidades. Entretanto, é no Centro-Oeste que a participação na oferta tem aumentado mais, em decorrência dos novos complexos industriais implantados naquela região.

Como grande produtora de cereais, essa região demonstra a tendência de deslocamento da atividade visando à redução dos custos de produção com base na proximidade da matéria-prima com as agroindústrias. Contudo, Talamini et al. (1998) concluíram que, no âmbito das vantagens comparativas, tratadas por meio dos custos, não há grandes diferenças regionais que possam remodelar a configuração geográfica das atividades avícola e suinícola.

Entretanto, ao analisar os dados do FNP Consultoria \& Agroinformativos (2003) sobre o crescimento do Market Share dos Estados da região Centro-Oeste, pode-se verificar que existe uma tendência de crescimento constante nos últimos anos. No final da década de 80 , o Centro-Oeste participava com pouco mais de $3 \%$ da produção 
brasileira; atualmente representa em torno de $8 \%$ da produção nacional de carne de frango de corte.

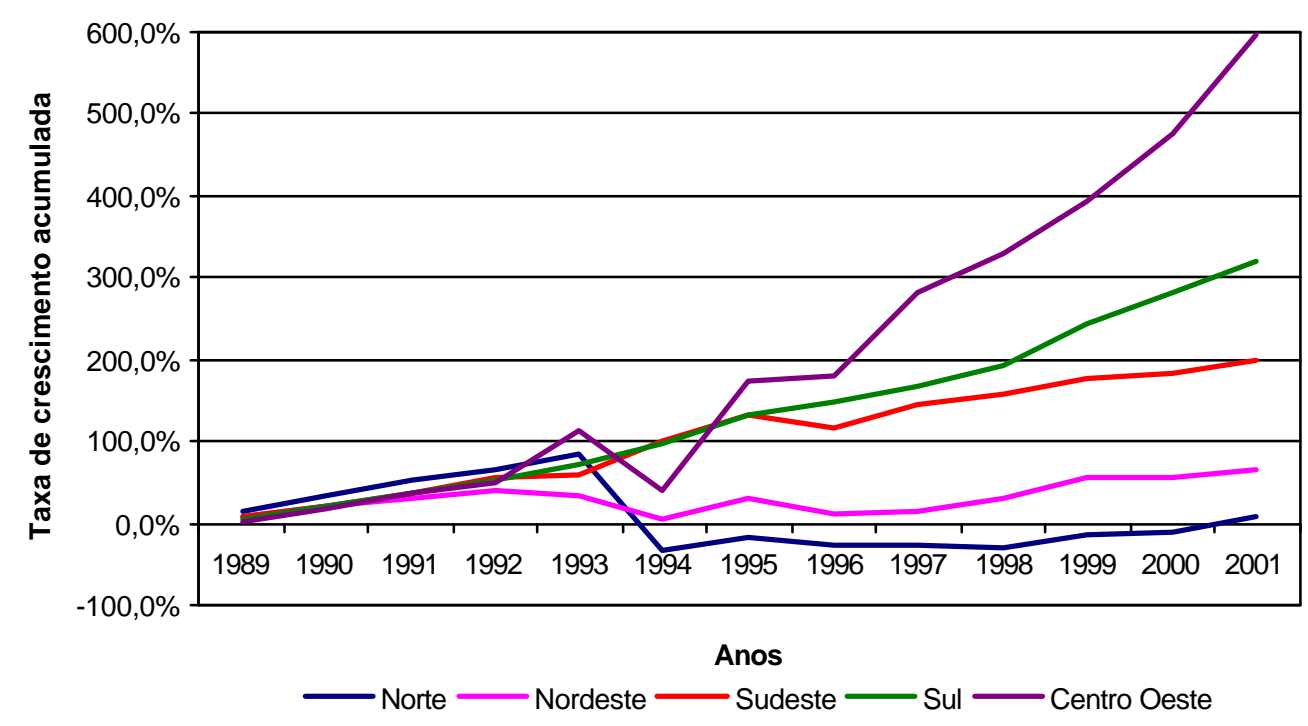

Figura 4 - Crescimento percentual da produção por região: 1988-2002 (Base 1988).

Fonte: FNP Consultoria \& Agroinformativos (2003)

A região Sul demonstra certa estagnação na participação nos últimos cinco anos. Várias são as possíveis explicações para esse fato, com destaque para duas. A primeira provém dos preços elevados da matéria prima - grãos -, que elevam os custos da ração utilizada para alimentar os frangos de corte. A outra vem da impossibilidade de crescimento das plantas industriais devido à pressão populacional existente. Assim, o crescimento das unidades produtivas está restrito, podendo ser uma das explicações da estagnação na participação produtiva do frango nos últimos anos.

Os cincos maiores Estados produtores de frango (Paraná, Santa Catarina, Rio Grande do Sul, São Paulo e Minas Gerais, respectivamente) foram responsáveis por aproximadamente $70 \%$ da produção nacional na década de 80 . A partir da instituição do Plano Real em 1994, houve um avanço significativo na participação desses Estados, sendo que o Market Share se elevou para $80 \%$ da produção brasile ira de carne de frango. 
A partir de 1996, ocorreu uma estabilização da produção desses Estados (Figura 5). Uma das hipóteses prováveis estará relacionada à depreciação dos preços nos mercados devido à elevação abrupta do volume produzido nos últimos cinco anos.

Conforme a Figura 5, percebe-se que, a partir de 1996, enquanto os cinco maiores produtores estagnaram seu Market Share, os Estados do Centro-Oeste continuaram sua escalada na busca de maior participação. Os efeitos desse movimento resultam da instalação de agroindústrias que detêm tecnologia de ponta nos processos produtivos, profissionalizando e especializando a produção avícola da região.

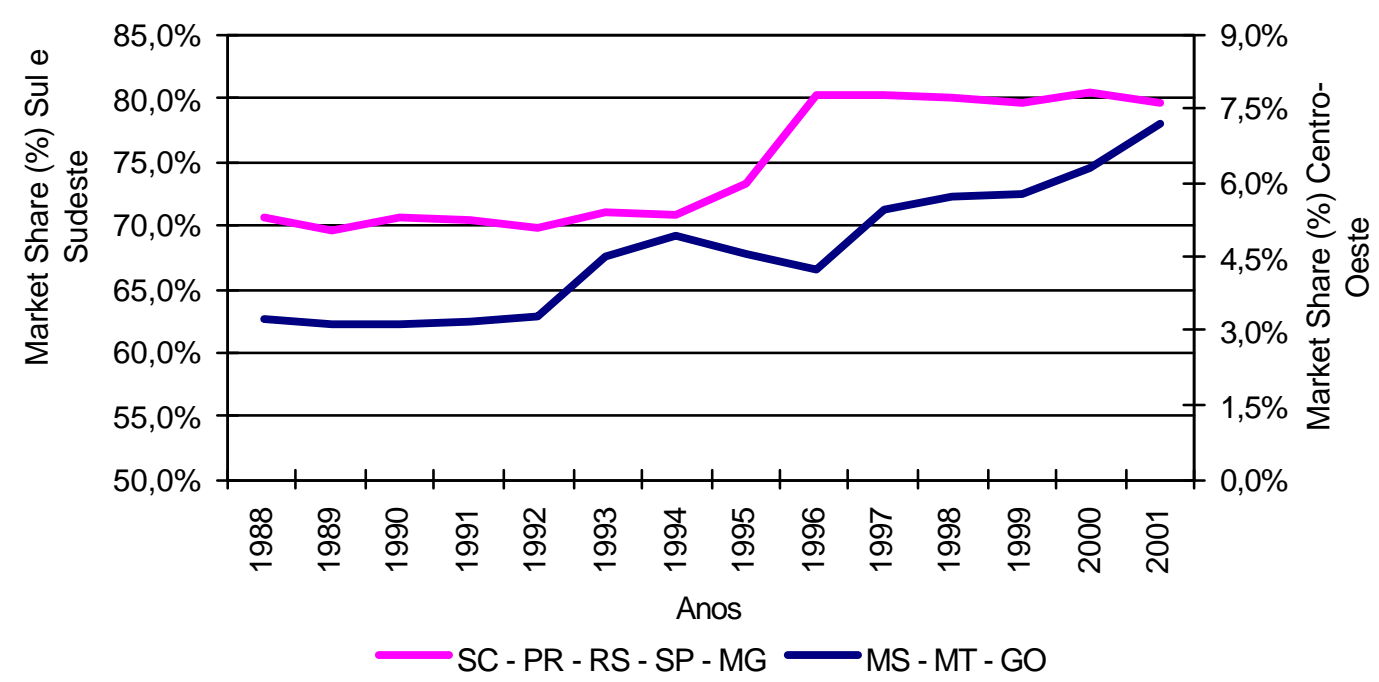

Figura 5 - Percentual do Market Share dos maiores Estados de 1988 a 2001.

Fonte: FNP Consultoria \& Agroinformativos (2003)

A maior concentração verificada na região Sul, de acordo com Câmara et al. (2000), que propiciou o crescimento da indústria avícola nessa região, foi fruto da associação das características regionais. As grandes empresas ${ }^{3}$ integradoras se instalaram nessa região devido à estrutura fundiária, baseada principalmente em

\footnotetext{
${ }^{3}$ A concentração do parque industrial das empresas encontra-se no Sul e Sudeste do País apresenta uma boa sedimentação, utilização de equipamentos e de tecnologia avançada no abate, evisceração, cortes e desossa das aves. Isso permite economia de escala e redução dos custos, proporcionando novos mercados consumidores de produtos de origem avícola com maior valor agregado. Apresenta também regularidade no fornecimento e uma especialização no atendimento às exigências dos consumidores como forma de se contrapor ao protecionismo dos países importadores.
} 
pequenos estabelecimentos agrícolas, permitindo a integração aos produtores avícolas. Aos poucos foram atraindo investimentos para as áreas de abate de aves e as empresas passaram a integrar-se verticalmente em quase todas as atividades ligadas ao abate.

\subsubsection{O tamanho das propriedades}

A predominância de pequenas propriedades foi um importante fator que auxiliou o crescimento da avicultura. Pode-se ver na Figura 6 que os tamanhos das unidades se restringem, na sua maioria, a áreas menores que 50 hectares.

Além das áreas limitadas, o terreno acidentado é uma barreira ao desenvolvimento de outras culturas, pois requer muitos esforços com mão-de-obra braçal para a realização das atividades produtivas. Esse detalhe favoreceu o surgimento da atividade avícola consorciada com a produção de suínos, como forma de diversificação das propriedades.

Essas características, aliadas às inovações tecnológicas, foram as responsáveis pelo desenvolvimento da atividade avícola na região Sul do Brasil, que foi marcado também pelo grande número de firmas correlatas que se instalaram nas circunvizinhanças.

Nota-se, assim, que a avicultura, junto com a suinocultura, possui importância decisiva no desenvolvimento da região Sul do Brasil.

Pelos dados do IBGE (1995/1996), as propriedades rurais na região Centro-Oeste do Brasil têm, em média, em torno de 100 ha, o que favorece a prática de culturas temporárias, como a de soja, milho, algodão, etc (Figura 7). As grandes extensões de terra, associadas às técnicas modernas de cultivo e ao alto nível tecnológico existente na região proporcionam maior oferta de grãos.

Contudo, em algumas mesorregiões, as condições climáticas não são as mais favoráveis para a produção de frango de corte. De qualquer forma, é preciso considerar que a avicultura é muito dinâmica e a adaptação dos ambientes necessários para a produção, com a utilização de linhagens robustas e de equipamentos modernos, torna possível a atividade avícola. 


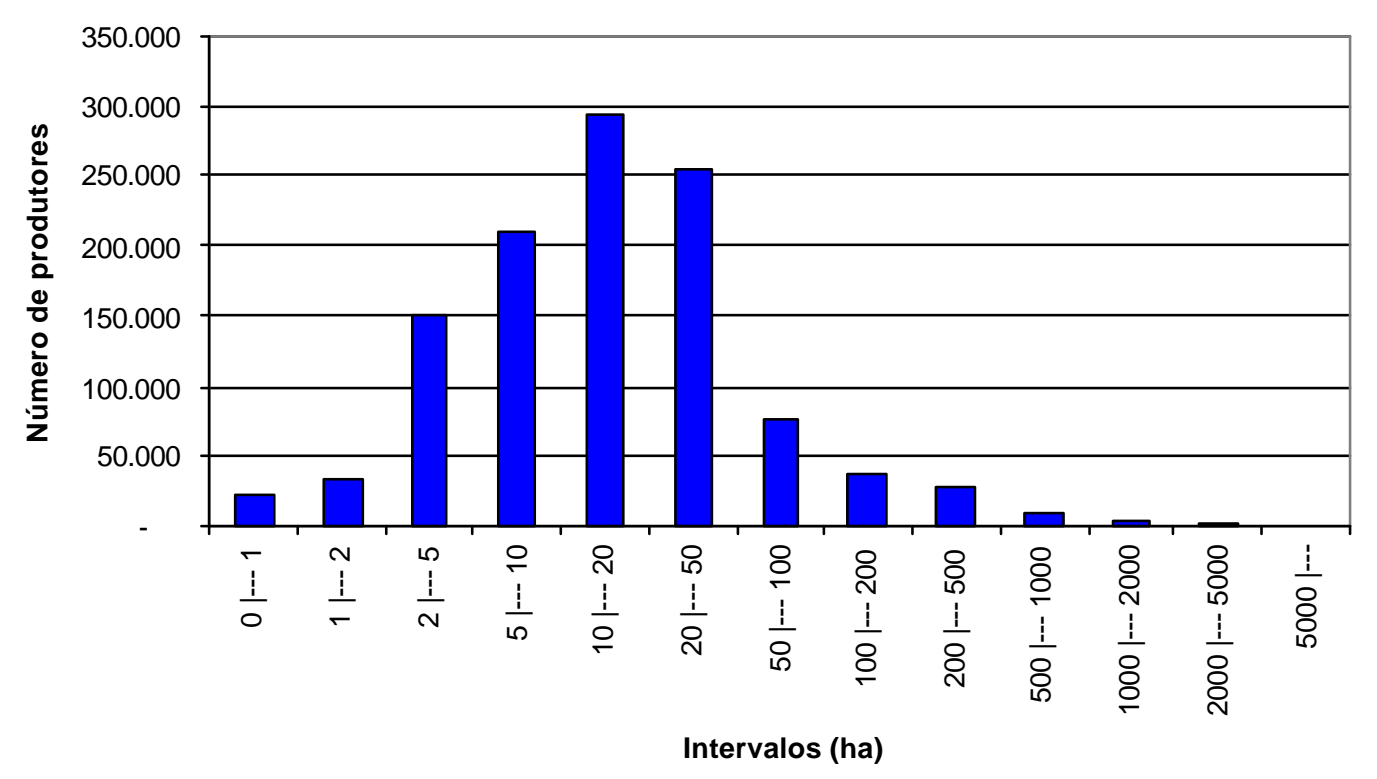

Figura 6 - Número de propriedades rurais na região Sul do Brasil por tamanho da área.

Fonte: IBGE (1995/1996)

Por outro lado, existem problemas referentes à adaptação da atividade à cultura das pessoas nativas, sendo uma barreira para o desenvolvimento da avicultura. Por isso, algumas empresas incentivam - dando apoio financeiro, facilidades de acesso a créditos e remunerações maiores - os produtores de regiões que possuem "know-how" na atividade a se deslocarem para o Centro - Oeste para ser produtores integrados e servir de modelo de manejo para os produtores que lá residem. Pode-se citar o exemplo do projeto Buriti/Perdigão, implantado na região sudoeste de Goiás.

Santana (1999) conclui, em seu trabalho sobre distribuição regional da produção de frango, que a questão cultural possui importância relevante na produção avícola. Ainda segundo o autor, essa tem sido a dificuldade de diversos empreendimentos do Brasil, embora, após treinamento adequado, a mão-de-obra, em geral, torna-se muito produtiva e criativa na busca por soluções para os problemas encontrados no desenvolvimento das atividades. 


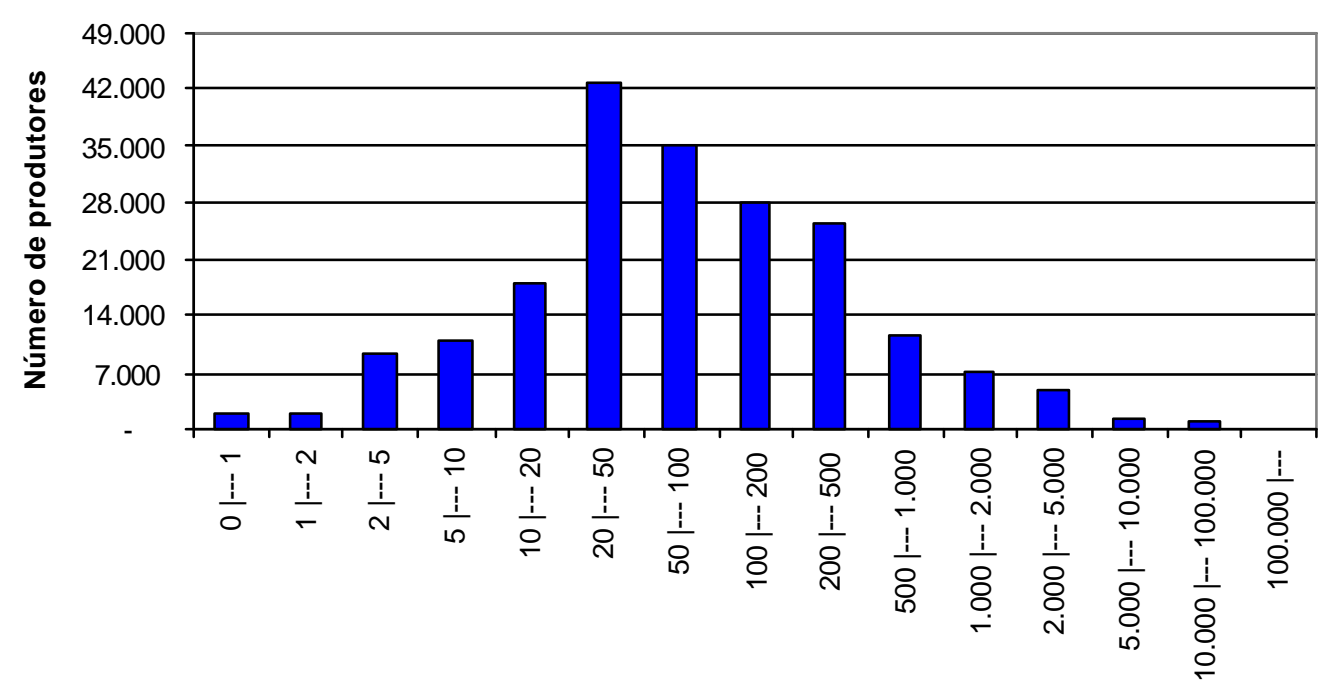

Intervalos (ha)

Figura 7 - Número de propriedades rurais na região Centro-Oeste do Brasil por tamanho de área.

Fonte: IBGE (1995/1996)

Diante de todas essas características, nota-se que uma série de fatores define o perfil, o tamanho e a capacidade das unidades produtivas no Centro-Oeste. A tendência do deslocamento da atividade avícola para regiões de fronteira e a intensificação no controle ambiental "obrigam" as empresas a se adaptarem às novas realidades, visando à formação de um conjunto de estratégias produtivas, comerciais e ambientais que lhes assegure espaço no competitivo mercado internacional.

Esse fenômeno não deve ser visto apenas como ameaça para as empresas, mas também como fonte de novas oportunidades para a dinamização e articulação das economias regionais. 


\subsubsection{Sistemas de produção}

As cadeias agroindustriais brasileiras dedicadas à produção de carnes encontramse em estágios de desenvolvimento distintos. No setor avícola, destaca-se a eficiente coordenação entre os agentes que compõem o sistema produtivo, chamada integração. Existe também uma classe de produtores que trabalha de forma independente representando, na atual conjuntura, um percentual minoritário dos produtores de frango de corte.

\subsubsection{Independentes}

A produção independente de frango de corte está relacionada a alguns traços culturais que inibem o associativismo e as parcerias. Esses produtores, segundo Richetti \& Santos (2003), não possuem vínculo de compra de insumos ou venda do produto com nenhuma empresa, formulam a ração na propriedade, adquirem os pintos de corte no mercado e contratam a assistência técnica de terceiros e/ou firmas especializadas. Esse sistema de produção normalmente vende seus produtos a pequenos estabelecimentos que preferem carcaças de menor peso.

Entretanto, os elevados custos de produção estão levando os produtores independentes a se integrarem junto às agroindústrias (integradoras), visando amenizar os efeitos das oscilações dos custos de produção e do preço da carne. Portanto, produtores que não suportam os constantes prejuízos migram para a integração ou encerram suas atividades.

Conforme Diniz (1998), com o elevado padrão de eficiência e concorrência a que o setor está exposto, no médio prazo, ocorrerá a extinção da categoria, principalmente aquela constituída pelos pequenos e médios avicultores independentes.

Por outro lado, os grandes criadores, percebendo a tendência do mercado de excluí-los no médio prazo, estão-se organizando em cooperativas ou, então, industrializam seus produtos em abatedouros próprios. 


\subsubsection{Integrados}

O setor avícola tem passado por um notável crescimento tanto no consumo doméstico quanto nas exportações, estando diretamente atrelado ao rígido sistema contratual entre os avicultores e abatedouros. De acordo com Alves Filho (1996), o sistema de produção por meio de contrato ou simplesmente integração é conhecido, tecnicamente, como uma articulação vertical que se estabelece entre as agroindústrias e os produtores rurais, em que o processo de produção é organizado de forma empresarial, com grandes inversões de capital e tecnologia.

Os produtores integrados recebem da agroindústria a que estão vinculados todos os insumos necessários ao processo de produção, bem como assistência técnica específica da atividade. Por sua vez, os agricultores produzem a matéria-prima - no caso o frango - para a agroindústria. O fluxograma destacado na Figura 8 demonstra o funcionamento simplificado do sistema de produção integrado entre os agentes envolvidos.

As empresas que atuam integradas verticalmente podem possuir menores custos de produção pelo fato de obterem uma maior produtividade ra criação das aves pelos criadores integrados, pela redução de estoques e do tempo ocioso dos ativos possibilitada pela programação da produção - e pela eliminação dos custos de transação, como custos de vendas, de compras e de negociações. Além disso, a integração pode ter proporcionado consideráveis ganhos de economia de escala, levando o setor a produzir com custos decrescentes e a fornecer ao mercado um produto a preços reais também decrescentes. Ferreira et al. (2000) sinalizaram que os índices de avaliação de produção na avicultura têm apresentado elevada eficiência nos últimos anos.

Segundo Talamini et al. (1998), a coordenação vertical, se por um lado facilita o aumento da escala de produção de frango, por outro cria a necessidade de desenvolvimento de contratos ou acordos formais entre os agentes para a diminuição dos riscos.

Os produtores - que normalmente se apresentam como os elos mais fracos da cadeia produtiva - exigem que sejam firmados contratos formais com a finalidade de 
diminuir os riscos envolvidos nas suas atividades e, com isso, proteger seu patrimônio e o trabalho gasto para a realização das atividades.

O vínculo entre as empresas integradoras e os avicultores se dá mediante várias formas e modalidades de contrato. A finalidade principal dos contratos para as agroindústrias é assegurar o fornecimento de frango com as especificações requeridas para o abate de forma estável e regular. Para o integrado, é uma maneira de garantir uma renda estável, na qual o fornecimento dos insumos e a assistência técnica estão a cargo das empresas.

Conforme Guimarães (1990) e Marques \& Aguiar (1993), o pagamento é efetuado de acordo com a taxa de conversão e mortalidade, como forma de prestigiar a eficiência da produção. Segundo Araújo \& Alves Filho (1998), a rentabilidade da avicultura integrada, em virtude de suas peculiaridades contratuais, tem-se revelado apenas satisfatória, exigindo dedicação e técnicas de manejo para obter sucesso. Além do valor recebido pelo lote de frango, o criador integrado procura conseguir o máximo de vantagens do subproduto esterco.

Para as empresas, os altos custos dos capitais, indispensáveis à produção agropecuária em grandes escalas, aliados a riscos inerentes ao setor primário, desestimulam a inversão intensiva de recursos. Daí surge a preferência pela utilização dos contratos de produção com os avicultores em vez de se apropriarem diretamente da produção como meio de assegurarem o abastecimento adequado da matéria-prima em quantidade suficiente e com qualidade satisfatória (Goldberg, 1974).

Guimarães (1990) observa que, quanto maior o número de etapas integradas, maior a facilidade de coordenar todas elas, resultando no aumento de eficiência, na redução da capacidade ociosa e instabilidade de produção, bem como na difusão mais fácil de tecnologia entre os segmentos envolvidos.

O sistema de integração vertical apresenta-se como um fator fundamental para a competitividade nas exportações de carne de frango. A alternativa de controle via integração proporciona um crescente grau de especificidade local, física, humana e "dedicada", capacitando o setor a adequar-se a diversos mercados. Esse conjunto de ativos específicos confere à carne de frango vantagens competitivas no mercado 
internacional ${ }^{4}$.

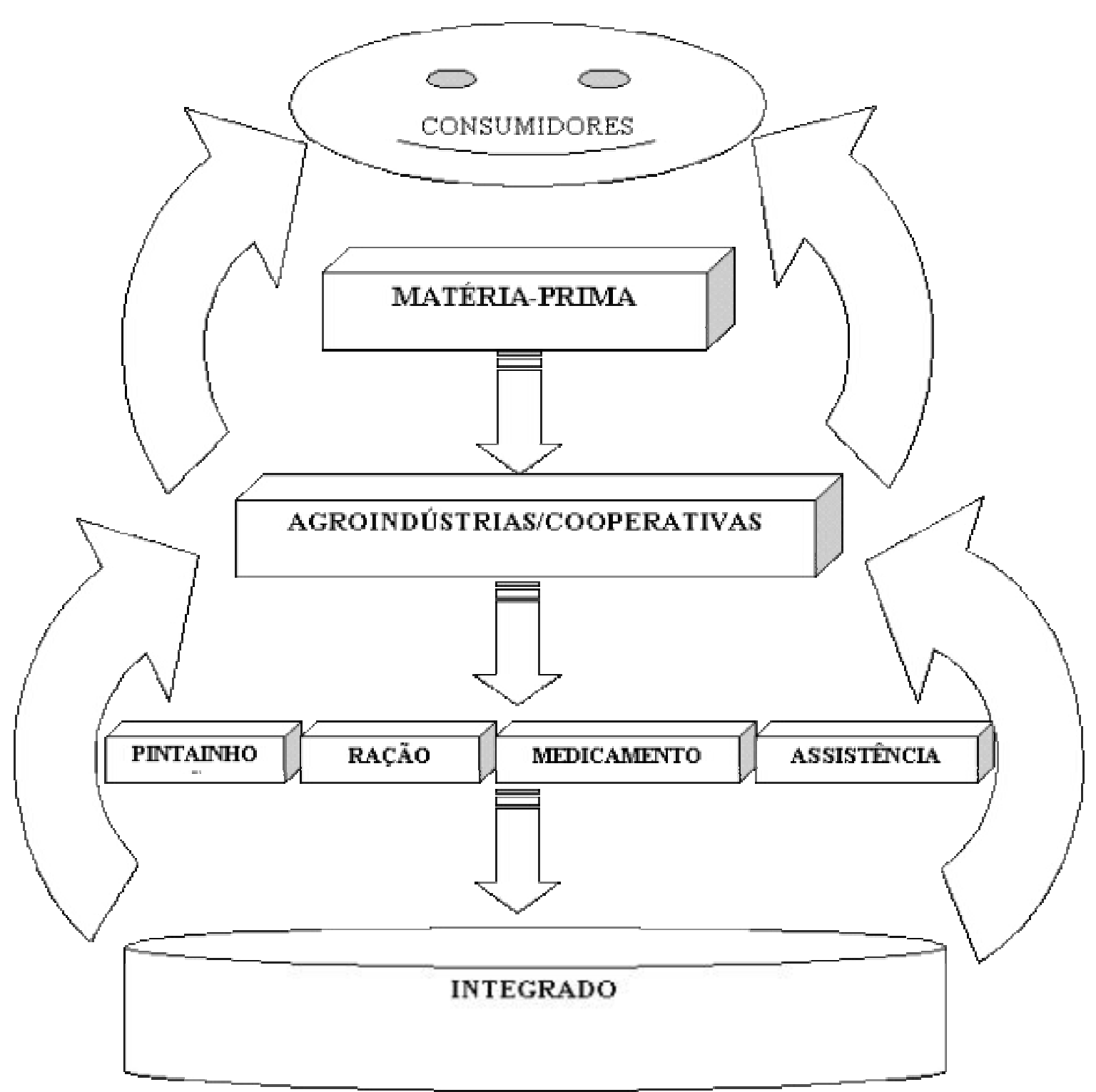

Figura 8 - Fluxograma do funcionamento do sistema de integração vertical.

Fonte: Dados de pesquisa.

A mão-de-obra da região Sul do Brasil - de origem basicamente européia - é considerada altamente qualificada, além dos valores familiares e de hierarquia que

\footnotetext{
${ }^{4}$ Destaca-se a oferta de cortes especiais de aves para os mercados mais ricos da Ásia, como o japonês, e do tipo "dedicada", quando as indústrias produzem o que os clientes desejam.
} 
caracterizam os operários industriais da região, tratando-se de uma especificidade humana importante para a competitividade no mercado mundial (Jank, 1997).

Essas vantagens competitivas são dependentes dos custos de produção do País, já que a base técnica é universal. Assim, as estratégias de coordenação dos diversos níveis da cadeia produtiva, conforme Streeter et al. (1991), são fundamentais para a satisfação dos interesses dos consumidores.

A coordenação dos vários níveis da cadeia produtiva tem facilitado a compreensão e agilizado as respostas às necessidades dos consumidores, garantindo um maior fluxo de informações entre o produtor rural e o consumidor.

Além das vantagens que a integração vertical confere às empresas, como a redução nos custos do produto final e o maior poder de barganha, entre outros, não resta dúvida de que a maior preocupação das agroindústrias é justamente com a qualidade do produto que será comercializado (Costa \& Araújo, 2001).

Porém, segundo Nunes (2000), mesmo que essa onda imitativa do processo de produção via integração contratual tenha ocorrido em função da maior eficiência frente a outros sistemas organizacionais de produção, a noção de eficiência precisa ser melhor entendida. Tal interpretação será feita nos tópicos seguintes.

\subsection{Características dos produtores de frango de corte amostrados nas regiões Sul e Centro-Oeste do Brasil}

As características existentes entre os Estados pesquisados mostram as principais diferenças encontradas na avicultura. Uma relevante verificada diz respeito à escala de produção, como se pode visualizar na Tabela 1.

Os produtores amostrados com escalas inferiores a 15.000 frangos/lote são vistos com maior intensidade em Santa Catarina, Minas Gerais ${ }^{5}$, Paraná e Rio Grande do Sul, com 41,3\%, 16\%, 16\% e 14,7\%, respectivamente. Esses Estados são considerados o

\footnotetext{
${ }^{5}$ Os produtores amostrados do estado de Minas Gerais foram excluídos do modelo, pois a atividade avícola possui características diferentes das demais. Entretanto, o Apêndice 5 fornece os coeficientes estimados para a região Centro-Oeste incluindo Minas Gerais.
} 
berço da avicultura brasileira e os locais onde primeiramente foi implantado o sistema de produção integrado, centrado em um modelo que consistia na integração do pequeno produtor e agroindústria.

Tabela 1. Percentual dos produtores amostrados por estratos de tamanho.

\begin{tabular}{lrrr}
\hline Estado & $0 \mid--15.000$ frangos & $15.000 \mid--45.000$ frangos & $45.000 \mid--500.000$ frangos \\
\hline GO & 0,0 & 8,0 & 65,5 \\
MG & 16,0 & 12,8 & 3,4 \\
MS & 4,0 & 16,0 & 10,3 \\
MT & 8,0 & 15,2 & 10,3 \\
PR & 16,0 & 5,6 & 0,0 \\
RS & 14,7 & 11,2 & 3,4 \\
SC & 41,3 & 31,2 & 6,9 \\
\hline
\end{tabular}

Fonte: Barros \& Zen, op. cit., p.13.

Entretanto, em Goiás, percebe-se a disseminação de um sistema de integração envolvendo médio/grande produtor. Nesse estado estão localizados aproximadamente $65,5 \%$ dos grandes produtores integrados. A principal característica observada está na exclusão do produtor com produção inferior a 15.000 frangos/lote. Segundo Fernandes Filho \& Queiroz (2001), a disseminação do sistema deverá reduzir drasticamente o número de pequenos integrados, q quantidade de pessoas que trabalham nos aviários e daquelas que prestam assistência técnica.

Verifica-se também um número diminuto de pequenos produtores em Mato Grosso do Sul e Mato Grosso, representando 4\% e 8\%, respectivamente.

Observou-se, na região Sul (RS, PR e SC) e em Minas Gerais, um predomínio de pequenas propriedades, sendo que áreas de terra de até 25 hectares representam respectivamente, $73,1 \%, 68,4 \%, 59,7 \%$ e $62,9 \%$ para esses estados (Tabela 2). Já em GO, MS e MT, as pequenas propriedades representam respectivamente 6,9\%, 30,8\% e 42,9\%. Propriedades de 51 a 100 hectares são mais representativas em MT, no PR, em 
MG e GO, representando respectivamente 21,4\%, 15,8\%, 14,3\% e 13,8\%. Áreas de 201 a 400 hectares destacam-se em Goiás (37,9\%) e Mato Grosso do Sul (11,5\%).

Tabela 2. Percentual de produtores da amostra por área de propriedade.

\begin{tabular}{lrrrrrrr}
\hline \multicolumn{1}{c}{ Hectares } & \multicolumn{1}{c}{ GO } & \multicolumn{1}{c}{ MG } & \multicolumn{1}{c}{ MS } & \multicolumn{1}{c}{ MT } & \multicolumn{1}{c}{ PR } & \multicolumn{1}{c}{ RS } & \multicolumn{1}{c}{ SC } \\
\hline $0|--| 25$ & 6,9 & 62,9 & 30,8 & 42,9 & 68,4 & 73,1 & 59,7 \\
$26|---| 50$ & 13,8 & 11,4 & 46,2 & 21,4 & 10,5 & 19,2 & 31,9 \\
$51|--| 100$ & 13,8 & 14,3 & 0,0 & 21,4 & 15,8 & 7,7 & 8,3 \\
$101|--| 200$ & 24,1 & 5,7 & 11,5 & 3,6 & 0,0 & 0,0 & 0,0 \\
$201|--| 400$ & 37,9 & 2,9 & 11,5 & 3,6 & 5,3 & 0,0 & 0,0 \\
$401|--| \mid 800$ & 3,4 & 2,9 & 0,0 & 0,0 & 0,0 & 0,0 & 0,0 \\
$1601|--| 3200$ & 0,0 & 0,0 & 0,0 & 7,1 & 0,0 & 0,0 & 0,0 \\
\hline
\end{tabular}

Fonte: Barros \& Zen, op. cit., p.13.

O mapeamento das origens étnicas e das peculiaridades de cada família rural ajudou na caracterização das regiões pesquisadas. Na porção Sul, as famílias são descendentes de imigrantes italianos e alemães, que produzem frangos no sistema de contratos de parceria. Apesar de pequenas, as propriedades possuem uma boa diversificação de atividades, como forma de sobrevivência. Além da avicultura, os produtores se dedicam à agricultura, à suinocultura e a outras atividades econômicas alternativas, como a criação de peixes e à fruticultura (principalmente uvas).

No estado de MS, a maioria dos criadores é migrante do Nordeste brasileiro que se fixaram em pequenas propriedades provenientes de assentamentos rurais implantados no governo do presidente Getúlio Vargas, destacando o baixo nível educacional das pessoas. Nas décadas de 70 e 80, os sulistas e os paulistas se instalaram na região. Isso resultou numa miscelânea de diversas culturas. Médios produtores, para as escalas de produção da região, também estão presentes na atividade.

Os avicultores instalados em Goiás, basicamente, migraram da região Sul. Obtiveram incentivos financeiros da agroindústria, como financiamento para compra de terras, aviários e equipamentos para produção. São pequenos produtores rurais 
diferenciados que migraram para a região acreditando no projeto da empresa e no retorno dos investimentos realizados.

Em MS, os pequenos produtores possuem uma dependência da renda da avicultura mais significativa que produtores maiores no universo de entrevistados, como se pode observar pelos dados da Tabela 3. Em relação ainda à dependência da atividade avícola, algumas exceções podem ser feitas, principalmente para os produtores oriundos da região Sul que diversificam a produção com culturas agrícolas e produção de leite e peixes.

Tabela 3. Percentual de produtores da amostra dependentes da renda avícola por Estado.

\begin{tabular}{|c|c|c|c|c|c|c|c|}
\hline Renda (\%) & GO & $\mathrm{MG}$ & MS & MT & PR & $\mathrm{RS}$ & $\mathrm{SC}$ \\
\hline \begin{tabular}{l|l|l|}
0 & --- & 10
\end{tabular} & 3,4 & 5,7 & 11,5 & 7,1 & 5,3 & 0,0 & 0,0 \\
\hline $11|---| 20$ & 6,9 & 5,7 & 11,5 & 0,0 & 0,0 & 3,8 & 11,1 \\
\hline $21|--| 30$ & 10,3 & 5,7 & 11,5 & 3,6 & 15,8 & 7,7 & 5,6 \\
\hline $31 \mid---40$ & 10,3 & 0,0 & 3,8 & 3,6 & 10,5 & 3,8 & 15,3 \\
\hline $41|--| 50$ & 24,1 & 14,3 & 0,0 & 17,9 & 15,8 & 23,1 & 22,2 \\
\hline $51|--| 60$ & 10,3 & 5,7 & 3,8 & 7,1 & 15,8 & 7,7 & 11,1 \\
\hline $61|--| 70$ & 10,3 & 8,6 & 7,7 & 21,4 & 0,0 & 7,7 & 18,1 \\
\hline $71|---| 80$ & 10,3 & 11,4 & 23,1 & 0,0 & 5,3 & 11,5 & 9,7 \\
\hline $81|--| 90$ & 3,4 & 11,4 & 7,7 & 21,4 & 5,3 & 19,2 & 4,2 \\
\hline 100 | $91 \mid-1$ & 10,3 & 31,4 & 19,2 & 17,9 & 26,3 & 15,4 & 2,8 \\
\hline
\end{tabular}

Fonte: Barros \& Zen, op. cit., p.13.

Os pequenos produtores avícolas detentores de pequenas propriedades em MT também diversificam suas atividades com a produção de suínos, leite e hortaliças.

Além do elevado nível de investimento inicial, as constantes inovações no setor exigem novas e altas inversões para alcançar os índices de produtividade exigidos pelo mercado. Por outro lado, em alguns casos a remuneração da produção não é atrativa frente ao volume desses investimentos, à especificidade dos ativos e à grande demanda de tempo que a atividade impõe. 


\subsection{Recursos financeiros}

As unidades de produção familiar desempenham importante papel no contexto social enquanto retentora de mão-de-obra no meio rural. Segundo dados do IBGE (1995/1996), representam aproximadamente 80\% dos estabelecimentos agropecuários. Atualmente, apesar do menor peso econômico - resultado da diferenciação social intensa sofrida, sobretudo a partir do processo de modernização da agricultura -, os agricultores familiares preservam uma participação significativa na produção agropecuária.

A importância social da agricultura familiar não foi suficiente, contudo, para garantir seu acesso aos benefícios do crédito rural farto e subsidiado nos anos 60 e 70, pois apenas um pequeno número desses produtores usufruiu os benefícios da política oficial de financiamento agrícola. De acordo com Schröder (2000), a política oficial de crédito rural beneficiou, desde sua criação nos anos 60 , principalmente a média e a grande propriedade, e marginalizou, mesmo sem apresentar uma postura claramente seletiva, parcela considerável dos agricultores familiares.

As novas fontes do crédito rural, especialmente os títulos, estão voltadas basicamente para o atendimento da agricultura comercial, porque a captação e a indexação dos recursos via mercado e os grandes volumes de produção necessários para a realização das operações inviabilizam-nas para as pequenas unidades de produção (Gasques \& Villa Verde, 1995b).

As exigências de garantias patrimoniais feitas pelas instituições financeiras tradicionais conferem ao crédito rural característica quase que proibitiva para as unidades de produção familiar.

As cooperativas de crédito rural constituídas a partir das cooperativas agropecuárias, especialmente ao longo da década de 80, também demonstraram capacidade limitada para gerar mudanças quando se considera a forma como se relacionam com os agricultores familiares. Seu atrelamento informal às cooperativas agropecuárias implicou a vinculação muito intensa com o modelo convencional de produção agrícola e, conseqüentemente, a exclusão dos segmentos de agricultores que 
não se encaixam no padrão tecnológico advindo desse modelo (Cazella \& Turnes, 1993). São organizações que, ao privilegiar os produtores modernizados ou integrados às agroindústrias processadoras no repasse dos recursos para o financiamento rural, dificultam o acesso dos agricultores pouco estruturados em termos técnicos e econômicos aos incentivos oficiais ou levam muitos agricultores a se ausentarem delas por sua própria iniciativa.

Pode-se observar, na Tabela 4, muitas das características mencionadas anteriormente. $\mathrm{O}$ número de produtores que utilizam crédito rural para a atividade avícola nas diversas regiões pesquisadas fornece informações relevantes sobre a política de crédito rural efetivamente praticada.

Os pequenos produtores, caracterizados por uma produção inferior a 15.000 frangos/lote, utilizam alguma forma de crédito rural em aproximadamente $92 \%$ das propriedades rurais amostradas. Entre esses, a região $\mathrm{Sul}(\mathrm{PR}, \mathrm{SC}$ e $\mathrm{RS}$ ) possui o percentual de pequenos produtores que mais necessitam de alguma forma de crédito rural, sendo $53 \%, 40 \%, 38 \%$, respectivamente.

Tabela 4. Número de produtores da amostra que utilizam crédito rural.

\begin{tabular}{|c|c|c|c|c|c|c|c|}
\hline & \multicolumn{2}{|c|}{$\begin{array}{c}0 \mid--15.000 \\
\text { frangos }\end{array}$} & \multicolumn{2}{|c|}{$\begin{array}{c}15.000 \mid--45.000 \\
\text { frangos }\end{array}$} & $\begin{array}{c}45.000 \mid-- \\
500.000 \text { frangos }\end{array}$ & \multicolumn{2}{|c|}{ Total } \\
\hline Estado & Não & Sim & Não & Sim & Não & Sim & \\
\hline GO & 0 & 0 & 0 & 10 & 0 & 19 & 29 \\
\hline MG & 0 & 12 & 5 & 11 & 0 & 1 & 29 \\
\hline MS & 1 & 2 & 0 & 20 & 0 & 3 & 26 \\
\hline MT & 0 & 6 & 1 & 18 & 0 & 3 & 28 \\
\hline PR & 2 & 10 & 0 & 7 & 0 & 0 & 19 \\
\hline RS & 1 & 10 & 4 & 10 & 0 & 1 & 26 \\
\hline $\mathrm{SC}$ & 2 & 29 & 1 & 38 & 0 & 2 & 72 \\
\hline Total & 6 & 69 & 11 & 114 & 0 & 29 & 229 \\
\hline
\end{tabular}

Fonte: Barros \& Zen, op. cit., p.13.

Entretanto, na região Centro-Oeste, o percentual de produtores que usam 
financiamentos para a atividade avícola representa $0 \%(\mathrm{GO}), 8 \%(\mathrm{MS})$ e $21 \%$ (MT) dos poucos pequenos produtores existentes.

Já os grandes produtores, representados por aqueles com uma produção superior a 45.000 frangos/lote, utilizam na sua totalidade os recursos oferecidos pelas instituições financeiras. Em Goiás, as grandes escalas de produção foram viabilizadas devido à liberação de recursos financeiros. Porém, esse privilégio é oferecido apenas a produtores que tenham elevada capacidade de alavancagem de financiamentos e estejam dispostos a obter incentivos fiscais (Fernandes Filho \& Queiroz, 2001).

Entre os médios produtores (produção entre 15.000 e 45.000 frangos/lote), apenas $9 \%$ dos produtores não usam os incentivos disponibilizados para a obtenção de financiamentos.

$\mathrm{Na}$ maioria das vezes, os recursos são oriundos de bancos públicos, principalmente o Banco do Brasil, com juros de 8,75\% ao ano, sendo que alguns utilizam recursos do Pronaf (Programa Nacional para a Agricultura Familiar) e do Proger (Programa de Geração de Emprego e Renda). Eles dependem de linhas de créditos para investimento, de garantias e de juros compatíveis com a remuneração proporcionada pela atividade.

As instituições financiadoras descritas pelos produtores são apresentadas na Tabela 5. As principais fontes de recursos relatadas são os bancos públicos, privados, as cooperativas de crédito, integradoras e outros, representando aproximadamente $77 \%$, $10 \%, 6 \%, 4 \%$ e $3 \%$, respectivamente.

Os produtores recorrem a financiamentos junto a terceiros, a fim de ampliar suas instalações. Pode-se visualizar na Tabela 6 os principais destinos do crédito rural levantado na pesquisa são para a construção das instalações. Esse percentual representa aproximadamente $66 \%$ dos produtores pesquisados. A aquisição de equipamentos tem representado $20 \%$ do destino dos recursos financeiros obtidos e o custeio da produção corresponde a $13 \%$. 
Tabela 5. Número de produtores da amostra por fontes de recursos financeiros.

\begin{tabular}{lrrrrr}
\hline Estado & Banco público & Banco privado & Cooperativa & Integradora & \multicolumn{2}{c}{ Outros } \\
\hline GO & 28 & 1 & 0 & 0 & 0 \\
MG & 19 & 1 & 1 & 0 & 0 \\
MS & 22 & 3 & 0 & 0 & 0 \\
MT & 15 & 2 & 2 & 8 & 0 \\
PR & 9 & 1 & 3 & 0 & 4 \\
RS & 17 & 0 & 4 & 0 & 0 \\
SC & 51 & 13 & 3 & 0 & 2 \\
Total & 161 & 21 & 13 & 8 & 6 \\
\hline
\end{tabular}

Fonte: Barros \& Zen, op. cit., p.13.

Os elevados custos das construções, conforme Fernandes Filho \& Queiroz (2001), exigem dos produtores uma maior capacidade de alavancagem de financiamento em função do aumento significativo nos custos de instalação de aviários. Por esse motivo, a construção torna-se o principal destino dos recursos provenientes do crédito rural.

Tabela 6. Número de produtores da amostra por destino de crédito rural.

\begin{tabular}{|c|c|c|c|c|c|}
\hline Estado & Custeio & Construções & Equipamento & Máquinas & Total \\
\hline GO & 0 & 29 & 0 & 0 & 29 \\
\hline MG & 6 & 14 & 1 & C & 21 \\
\hline MS & 5 & 19 & 1 & 0 & 25 \\
\hline MT & 4 & 20 & 3 & 0 & 27 \\
\hline PR & 2 & 7 & 8 & 0 & 17 \\
\hline RS & 4 & 13 & 4 & C & 21 \\
\hline SC & 6 & 36 & 26 & 1 & 69 \\
\hline Total & 27 & 138 & 43 & 1 & 209 \\
\hline
\end{tabular}

Fonte: Barros \& Zen, op. cit., p.13.

É importante ressaltar que não serão somente a existência de taxas de juros subvencionadas ou a suficiência de recursos que garantirão, por si só, um financiamento 
condizente com a realidade dos produtores familiares e seu acesso aos eventuais benefícios desse crédito, pois são muitas dificuldades para que se articulem os interesses das instituições financeiras e da agricultura familiar.

\subsection{A competitividade da cadeia avícola em nível dos produtores}

A maior parte dos estudos recentes costuma tratar a competitividade como um fenômeno diretamente relacionado às características de desempenho ou de eficiência econômica.

Nesse sentido, Ferraz et al. (1995) identificaram duas vertentes de entendimento do conceito de competitividade. A competitividade revelada é vista como o desempenho de uma empresa ou produto. É de alguma forma expressa na participação no mercado alcançada por uma unidade produtiva em um mercado em certo momento do tempo. Assim, a participação nas exportações pode ser um bom indicador de competitividade da cadeia avícola, ou seja, é a demanda de mercado que dirá quais produtos de quais empresas serão adquiridos, definindo a posição competitiva das empresas.

Em nível de produtor de frango de corte, essa opção do mercado fica restrita ao sistema de produção integrada. Nesse caso, o produtor inicia a produção tendo a garantia de compra por parte da agroindústria.

Dando seqüência às vertentes do entendimento da competitividade, temos a competitividade revelada. Vista como eficiência, busca de alguma forma traduzir a competitividade de uma cadeia produtiva pela relação insumo - produto praticada pelas firmas, ou seja, identifica a capacidade da unidade produtiva de converter insumos e produtos com o máximo rendimento.

Porém, tanto o desempenho quanto a eficiência são enfoques limitados por serem estáticos analisando-se apenas o comportamento passado dos indicadores, sem elucidar as relações causais que mantêm com a evolução da competitividade. Portanto, a eficiência garante algumas fontes de competitividade, mas não a competitividade em si. 


\subsubsection{Fatores determinantes da competitividade}

Existe um conjunto de fatores que transcendem o nível da firma, estando relacionados à estrutura da indústria e do mercado, e ainda ao sistema produtivo como um todo.

A gestão competitiva, a capacitação para produzir e inovar e os recursos humanos com alta produtividade são apenas uma parte do problema competitivo. Entretanto, o mercado, a configuração da indústria e o regime de incentivos e regulação da concorrência constituem fatores estruturais igualmente decisivos para a competitividade.

O mercado, segundo Ferraz et al. (1995), é seguramente um dos principais fatores indutores da competitividade. Ao estimular os investimentos, os mercados dinâmicos asseguram uma elevada taxa de renovação de equipamentos e métodos de produção que, ao lado das economias de escala, proporcionam crescimentos sustentados da produtividade industrial.

Nos setores de elevada intensidade de capital, as empresas optaram por especializar as linhas de produtos afins em termos da base tecnológica ou da área de comercialização em vez de empregar em portfólios de produtos. Já os de menor intensidade de capital, a solução identificada por Ferraz et al. (1995) seria a formação de redes cooperativas horizontais, cuja função é proporcionar uma maior eficiência empresarial ou a disponibilização de recursos produtivos essenciais para a operação em condições competitivas, as quais isoladamente não poderiam ter acesso.

Os ambientes de elevada rivalidade interempresarial favorecem a competitividade, pois submetem as empresas a esforços contínuos de melhoria da eficiência produtiva e de inovação nos produtos e métodos de produção. Assim, as empresas buscam o pioneirismo na introdução de produtos, processos e sistemas.

Os incentivos visam aumentar a capacidade de resposta das empresas diante dos desafios impostos pela economia e as regulamentações buscam condicionar as suas condutas em direções socialmente desejáveis. O aprimoramento dessas regulamentações tem-se revelado importante mecanismo de estímulo para o aumento da eficiência 
produtiva e principalmente para a melhoria da qualidade e para o crescimento do grau de sofisticação tecnológica nos processos.

As condições sociais vigentes em uma economia têm importantes efeitos sobre a competitividade das unidades produtivas que nela operam, particularmente no que diz respeito à educação e qualificação da mão-de-obra, à natureza das relações trabalhistas e ao padrão de vida dos consumidores.

\subsection{Fatores ambientais relacionados à ineficiência}

A significativa concentração da produção avícola brasileira ocorre sobretudo na região Sul. Ao analisar a Figura 9, referente à densidade animal existente nas principais mesorregiões produtoras, percebe-se nitidamente a elevada concentração da produção no Oeste Catarinense, um dos berços da avicultura, seguido pelo Oeste Paranaense, Centro Oriental Rio-Grandense e região metropolitana de Curitiba. A densidade dessas regiões chega a 30,04 cabeças/ha, indicando grande plantel de frango de corte.

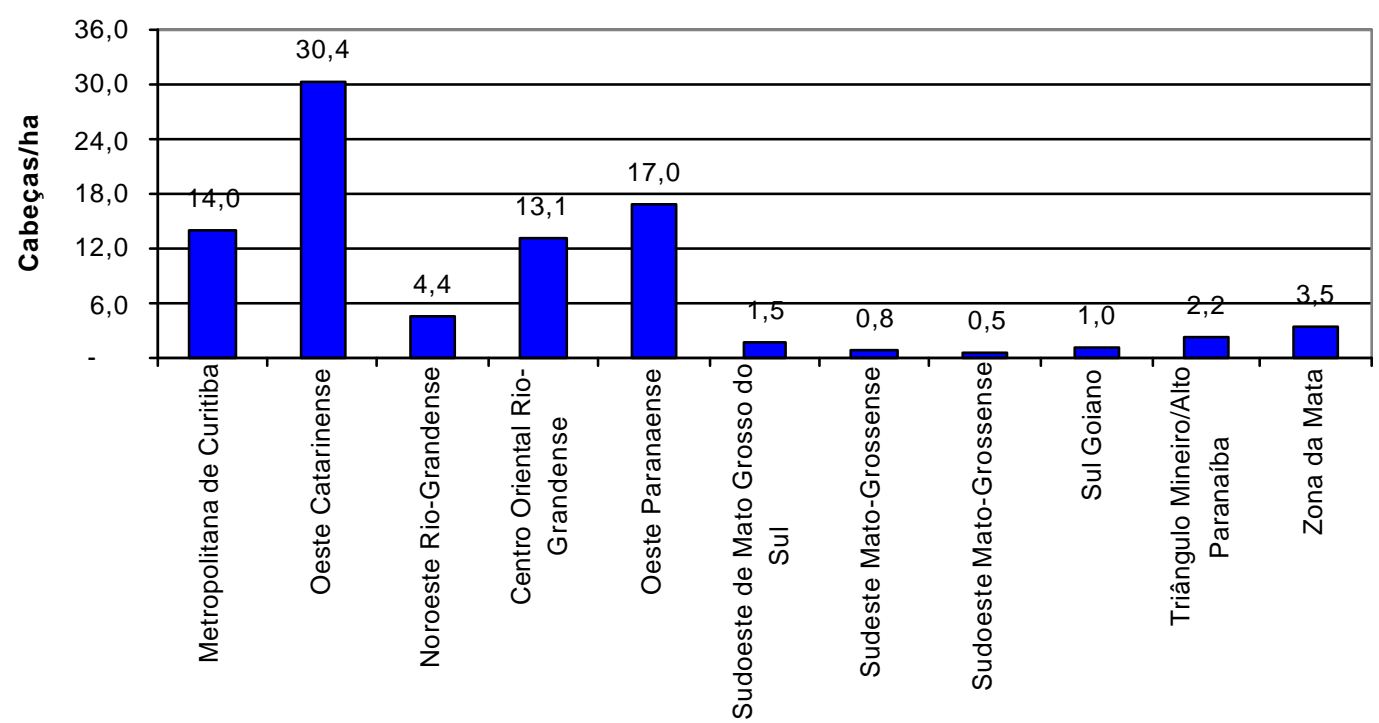

Figura 9 - Densidade de animais nas mesorregiões pesquisadas (cabeças/ha).

Fonte: IBGE (2001)

Entretanto, analisando as mesorregiões localizadas no Centro-Oeste, nota-se que 
a região não possui a avicultura como uma das principais atividades. Porém, o desenvolvimento da avicultura está acontecendo num ritmo acelerado, mas controlado.

O aumento da consciência humana para a questão ambiental tem gerado maior atenção aos seus impactos. Existem dois tipos de impactos provenientes da atividade animal que afetam o meio ambiente: o direto e o indireto.

O primeiro diz respeito aos impactos ambientais diretos. Esses são externalidades negativas que exercem efeitos conforme as condições de armazenamento dos dejetos: na água e na atmosfera, pela emissão de metano; e sobre as plantas e animais, por meio da competição com os recursos naturais. A concorrência por maiores áreas de terra para o desenvolvimento das atividades pecuárias pode levar o avanço das áreas de grãos sobre os limites dos recursos naturais (florestas, rios, etc).

$\mathrm{O}$ segundo, que trata os impactos ambientais indiretos, relata a demanda natural dos animais por alimentação e a associação do impacto ambiental dos sistemas de alimentação disponíveis para o setor. Nesse sentido, tem-se ciência dos avanços impostos, sobretudo pelas das culturas temporárias, nas regiões Centro-Oeste e Norte do País, visando suprir a demanda por grãos (milho, soja, arroz, etc.).

Porém, existem as externalidades positivas para a sociedade que aparecem por intermédio da utilização dos dejetos como fertilizantes, evitando, assim, impactos ambientais associados com a produção e o uso de fontes alternativas.

O manejo dos dejetos animais nas propriedades é parte integral da administração delas. Segundo Schmitt \& Rehm (1998), o manejo deveria ser um tópico prioritário nas propriedades produtoras de frango de corte no século XXI, pois um processo adequado proporcionará ao agricultor maior eficiência da produção com a obtenção de uma renda extra que. Isso favorecerá a minimização dos gastos com mitigação ambiental envolvidos no processo de produção mediante o correto destino dos dejetos.

\subsubsection{Responsabilidade}

Historicamente, o desenvolvimento da produção animal tem respondido às oportunidades agroecológicas e a demanda por produtos animais, e tem-se envolvido 
num sistema ambiental sustentável. Mas, nos últimos anos, muitos dos sistemas produtivos podem estar se deslocando para além do seu equilíbrio.

O desequilíbrio ocorre devido à pressão existente sobre os meios para a obtenção de mais produtos de origem animal. $\mathrm{O}$ excesso de produção de dejetos é a principal carga ambiental da produção intensiva de frango de corte. A degradação dos recursos ambientais causada pela disposição dos dejetos resulta em um excesso de oferta de nutrientes no solo ${ }^{6}$, na água ${ }^{7}$ e no ar $^{8}$.

A disposição dos dejetos é um custo para todos os agentes, inclusive para os produtores de frango e de outros animais. Assim, o objetivo principal da disposição dos resíduos é minimizar o custo para a sua atividade. Para obter esse resultado, usa-se a imposição, pela sociedade, dos padrões ambientais sobre os agentes como forma de permanecerem no setor.

A regulamentação de leis de responsabilidade ambiental cria um problema crônico para os agentes envolvidos com uma demanda reguladora que vislumbra os dejetos como custos de responsabilidade para os agentes, criando uma barreira para o desenvolvimento das indústrias.

As pessoas beneficiadas com a exploração e disposição não pagam o gasto com mitigação ambiental da utilização daquele produto. Entretanto, aqueles que preservam os recursos ambientais ou que pagam o custo de conservação recebem pouco ou nenhum benefício.

Para isso ser resolvido, outros mecanismos de ajuste do desequilíbrio devem ser criados para beneficiar as pessoas que preservam os recursos naturais, enquanto os degradantes pagam pelos gastos com mitigação ambiental. Segundo Steinfeld et al.

\footnotetext{
${ }^{6}$ Segundo Smith (2002), a adição excessiva de nutrientes, uma situação que comumente ocorre durante a disposição dos dejetos, pode causar um significativo impacto ambiental, e o excesso de nutrientes não eleva a produção de grãos podendo, em alguns casos, inibir o crescimento das plantas.

${ }^{7}$ Conforme Perdomo et al. (2001), o problema da adição de dejetos aos recursos hídricos resulta do rápido aumento populacional das bactérias e da extração do oxigênio dissolvido na água que é utilizado para o seu crescimento.

${ }^{8}$ A poluição do ar e a incidência de doenças, de acordo com Perdomo et al. (2001), estão relacionadas com a perda da qualidade do ar nas edificações. Cerca de 50\% dos animais criados em sistema de confinamento apresentam problemas de saúde e muitos produtores tornam-se precocemente incapacitados para o trabalho, devido aos danos causados em seu sistema respiratório pela exposição constante a ambientes com elevadas concentrações de poeira e gases.
} 
(2002), as interações são muito complexas e as pessoas não são facilmente identificadas.

A situação existente, a princípio, não tem tratado os efeitos ambientais com a devida importância, pois não existe regulamentação ou taxação alguma que forneça imposições sobre o volume produzido de dejetos e as formas de utilização, a não ser pela impossibilidade de utilização para a alimentação animal.

O incentivo à implantação de formas alternativas de utilização da cama, como, por exemplo, biodigestor, necessita de subsídios por parte das instituições públicas para viabilizar essa forma de tratamento. Por enquanto, os benefícios econômicos para os produtores ainda não são compensadores frente aos preços atuais da energia.

Um procedimento rotineiro dos produtores de frango de corte é a transferência do ônus da responsabilidade ambiental para uma terceira pessoa que detém área territorial suficiente para a disposição dos mesmos sem causar qualquer impacto negativo ao meio ambiente. Para o produtor, há a formação de uma renda correspondente à venda dos resíduos que é incorporada à renda do lote de frango de corte para formar, muitas vezes, a renda total das propriedades.

Com isso, a cama de frango produzida no Brasil possui um valor de comercialização que pode ser visualizado na Figura 10. Os dados obtidos da pesquisa de Barros \& Zen, op. cit., p.13 em parceria com FAO demonstram que os resíduos produzidos pela atividade avícola nas mesorregiões estudadas possuem valores médios significativamente maiores na região Centro-Oeste do que na região Sul. Os valores atingiram R\$ 51,11/t na Zona da Mata Mineira e R\$ 23,83/t no Sudoeste MatoGrossense, que, comparados com os números obtidos no Sul - onde o maior preço foi de $\mathrm{R} \$ 16,39 / \mathrm{t}$ e o menor de $\mathrm{R} \$ 4,06 / \mathrm{t}$-, são absolutamente maiores.

Verificam-se alguns resultados interessantes sobre a produção de frango de corte nessas regiões. O preço menor da cama de frango no Sul estaria indicando uma possível saturação das terras que estariam reduzindo a demanda. Com isso, o impacto ao meio ambiente com a depreciação do preço da cama de frango seria significativo, pois não haveria mais estímulos, por parte dos produtores, de realizarem os controles ambientais necessários. 


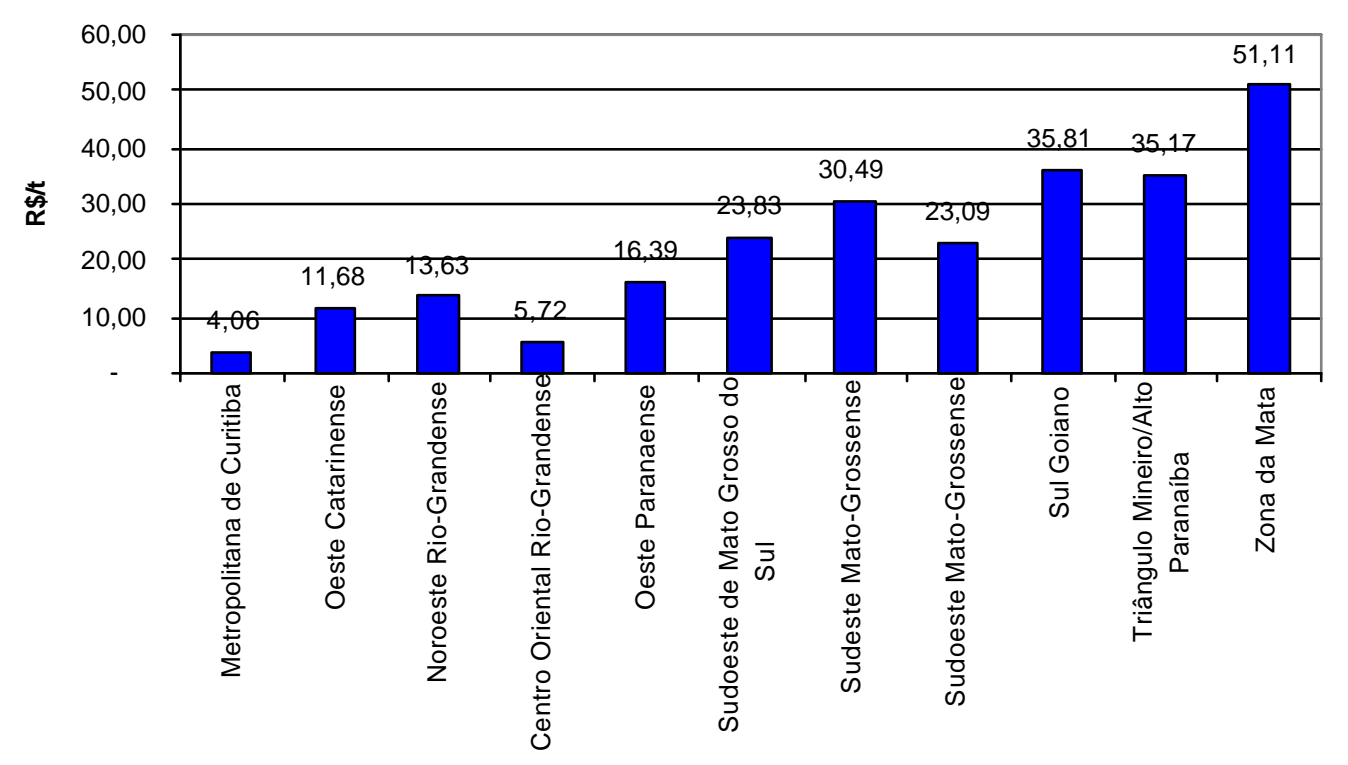

Figura 10 - Preço médio do resíduo (cama de frango) nas mesorregiões pesquisadas em $\mathrm{R} \$ / \mathrm{t}$.

Fonte: Barros \& Zen, op. cit., p.13.

\subsubsection{Gastos com mitigação ambiental}

A valorização econômica do efeito ambiental nas áreas de produção de frango de corte pode ser conhecida, embora dependa de grande número de variáveis. Os gastos com mitigação ambiental, associado com a produção animal intensiva, segundo Ap Dewi et al. (1994), são os custos correspondentes à disposição dos dejetos que podem causar poluição, incluindo o destino dos animais mortos. Assim, as despesas com disposição dos dejetos são consideradas como o custo interno direto para os produtores de animais.

As externalidades negativas que não recaem sobre o produtor, mas sobre a sociedade são outros exemplos de externalidades. Isso inclui a poluição do solo, do ar e da água, resultado da disposição inadequada dos dejetos (Ap Dewi et al., 1994). Porém, 
conforme Randall (1987), esses custos, por não serem bens exclusivos ${ }^{9}$ e, às vezes, bens não rivais ${ }^{10}$, não são passíveis de valoração.

De acordo com Steinfeld et al. (2002), existem duas aproximações básicas para atenuar os efeitos do excesso de dejetos produzidos pela produção de frango de corte. A primeira medida fundamenta a utilização de soluções técnicas para o manejo dos dejetos, mediante a regulamentação sobre os procedimentos de estocagem e/ou aplicação no solo. A segunda tem como objetivo a mudança da localização geográfica dos sistemas de produção.

Isso tem sido fomentado pelas medidas que prescrevem as distâncias recomendadas das áreas residenciais para a localização das unidades de produção (aviário) e das áreas de disposição dos dejetos; o número máximo de animais por $\mathrm{m}^{2} \mathrm{e}$, até mesmo, se necessário, a retirada do produtor da atividade.

Assim, a instituição dessas diretrizes pode ser suportada pela imposição de multas ou por meio de subsídios que forneça incentivos para a introdução de técnicas ambientais de tratamento e estocagem. O surgimento de tecnologias para melhorar a coleta e estocagem dos resíduos pode ajudar significativamente as regiões onde não exis te demanda, devido ao aumento do valor nutricional e monetário dos resíduos.

Além disso, a disponibilidade e efetividade de ambas as técnicas e opções políticas são fortemente dependentes de variáveis naturais e das condições socioeconômicas dos produtores.

Segundo estudo de Steinfeld et al. (2002), em muitos casos a adoção de tecnologias ambientais em algumas áreas inviabiliza a produção a menos que a economia com fertilizantes minerais seja maior do que o custo da implantação. Portanto, conforme Wit et al. (2002), a produção intensiva de animais em algumas áreas de terra

\footnotetext{
${ }^{9}$ Segundo Randall (1987), a característica de um bem não exclusivo considera que não é possível excluir um indivíduo do consumo, seja de um bem, seja de um serviço, porque o custo de exclusão dele seria muito maior que o benefício recebido. Sem exclusão, não é possível obter um preço de mercado para o seu uso, e isso poderá resultar numa superexploração do recurso em relação ao nível de eficiente, ocasionando a sua degradação.

${ }^{10}$ De acordo com Randall (1987), bens não rivais são aqueles bens ou serviços que uma vez produzidos, estão disponíveis a todas as pessoas sem rivalidade, ou seja, o bem consumido por um agente não reduz a quantidade a ser consumida por outros consumidores.
} 
poderá ser desestimulada - ainda que possa ser economicamente viável - devido à relevância que a questão ambiental está impondo aos produtores. 


\section{MODELO ECONÔMICO}

\subsection{Medidas de eficiência}

"A contínua criação/introdução de novas tecnologias tem sido usada como padrão para distinguir a agricultura moderna da agricultura tradicional" (Schultz, 1964).

Diante do sistema de produção capitalista, a atividade produtiva está fortemente relacionada com a obtenção de lucros, ou seja, o retorno sobre o capital investido. Isso propõe que a atividade produtiva deve buscar a eficiência econômica.

A teoria neoclássica da produção está baseada na noção de eficiência, sendo sua conceituação iniciada com Farrell (1957), que propôs um modelo empírico para medir eficiência relativa, em contraste com o modelo de função de produção teórica.

Segundo esse autor, era melhor determinar a medida de eficiência de uma firma comparando-a com o melhor nível de eficiência até então observado do que compará-la com algum ideal inatingível. Assim, a fronteira de eficiência nessa formulação é construída pelos valores observados de insumos e produtos, e não por valores estimados.

A comparação com o melhor produtor é uma forma de não realizar a comparação com produtores inexistentes. Quando se utiliza um produtor como parâmetro, chega-se à distância entre a posição do produtor mais eficiente e a do produtor comparado.

Com a comparação dos níveis de insumos e produtos de um produtor com os possíveis níveis encontrados, ter-se-á a eficiência técnica de um produtor. Quando esses níveis existem, os quais estritamente dominam o produtor que está sendo testado, então esse produtor é ineficiente. Inversamente, um produtor será eficiente quando nenhum 
outro produtor ou conjunto de produtores produzem mais bens com os mesmos ou menos insumos.

Segundo Kumbhakar (1994), a ineficiência não é totalmente técnica. Se o produtor errar na alocação dos insumos, a ineficiência resultante é denominada de alocativa. Erros na alocação dos recursos e na otimização dos níveis de produtos aumentam os custos e, portanto, diminuem o lucro.

A inclusão dos preços dos insumos fornece a eficiência alocativa. Essa se traduz na habilidade que os produtores têm no momento de escolher um nível ótimo de insumos para dados preços dos fatores. Assim, quanto mais o produtor racionaliza esses níveis de fatores, maior será a sua eficiência alocativa. Inversamente, quanto mais distante das proporções ótimas, mais ineficientes eles serão.

O produto da eficiência técnica pela alocativa resulta na eficiência econômica. Ela é definida como a capacidade que o produtor possui de maximizar seu rendimento dados as técnicas de produção disponíveis, as quantidades de fatores fixos e os preços dos produtos e dos insumos (Farrell, 1957).

\subsection{Conjunto de possibilidades de produção}

O produtor usa uma tecnologia de produção para, a partir de um vetor de insumos, denotado $x=\left(x_{1}, \ldots x_{n}\right) \in \mathfrak{R}_{+}^{n}$, produzir um vetor de produtos, $y=\left(y_{1}, \ldots y_{m}\right) \in \mathfrak{R}_{+}^{m}$.

O conjunto de possibilidades de produção de um produtor é um subconjunto I do espaço $\Re_{+}^{m+n}$. Uma planta de produção pode selecionar qualquer configuração de insumo - produto $(x, y) \in I$. O conjunto de possibilidades de produção é um apanhado de todos os vetores praticáveis de insumos e produtos, sendo representado como $I=\{(y, x): x \Rightarrow y\} \subset \mathfrak{R}_{+}^{m+n}$.

Adicionalmente, conforme Färe et al. (1994), o conjunto pode ser representado pelo conjunto dos insumos $\mathrm{L}(\mathrm{y})$ ou conjunto de produtos $\mathrm{P}(\mathrm{x})$. O primeiro representa uma coleção de todos os vetores de insumos $x=\left(x_{1}, \ldots x_{n}\right) \in \mathfrak{R}_{+}^{n}$ que produz no mínimo 
um vetor de produtos $y=\left(y_{1}, \ldots y_{m}\right) \in \mathfrak{R}_{+}^{m}$, sendo representado como $L(y)=\{x:(x, y)\}$.

O segundo conjunto é um "misto" de todos os vetores de produtos $y=\left(y_{1}, \ldots y_{m}\right) \in \mathfrak{R}_{+}^{m} \quad$ que são produzidos de um dado vetor de insumos $x=\left(x_{1}, \ldots x_{n}\right) \in \mathfrak{R}_{+}^{n}$. Isso é denotado por $P(x)=\{y:(x, y)\}$. Esses são ilustrados na Figura 11 .

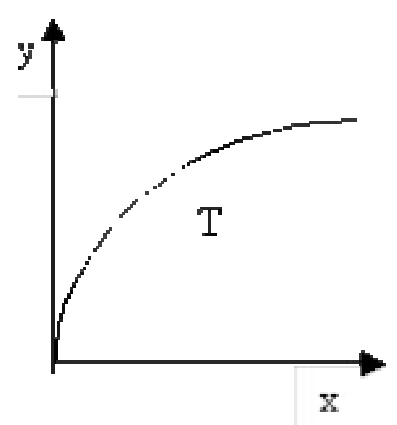

a) Possibilidade de produção

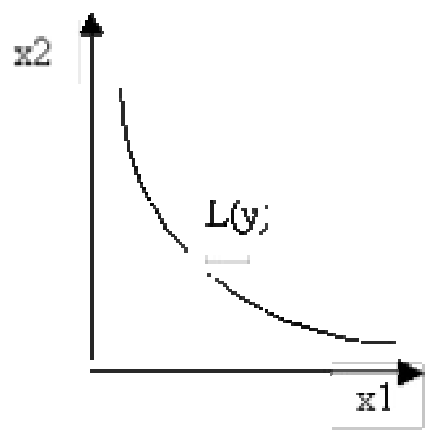

b) Conjunto de insumos

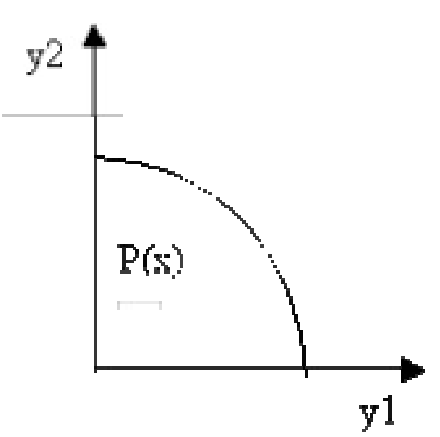

c) Conjunto de Produtos

Figura 11 - Conjunto de possibilidades de produção.

Fonte: Kebede (2001)

\subsection{Fronteiras de produção}

Para ilustrar o conceito de fronteira de produção, pode-se usar uma importante classe de funções de produção que relacionam um vetor de produtos y a um vetor $n$ dimensional de insumos $\mathrm{x}$, supondo que $T(x, y) \geq 0$ seja satisfeito, em que $T(x, y)$ representa o conjunto de possibilidades de produção. Uma representação geral da tecnologia de fronteira é dada como:

$$
y=f(x) .
$$

A função $f($.$) é a fronteira de produção que fornece o limite superior de I.$ 
Assim, dados os insumos $\mathrm{x}$, o máximo produto $y=f(x)$ pode ser encontrado, e expresso por $f(x)=\max \left\{y^{\prime}: I\left(x, y^{\prime}\right) \geq 0\right\}$

A fronteira de produção serve para medir a eficiência técnica da produção. Ela pode possuir algumas propriedades quanto às economias de escalas:

* Retornos constantes à escala: uma tecnologia de fronteira exibe retornos constantes à escala se $f(t x)=t f(x) \forall t>0$, com t sendo uma constante.

* Retornos decrescentes à escala: uma tecnologia de fronteira exibe retornos decrescentes à escala se $f(t x)<t f(x) \forall t>1$ com t, sendo uma constante.

* Retornos crescentes à escala: uma tecnologia de fronteira exibe retornos crescentes à escala se $f(t x)>t f(x) \forall t>1$, em que t é uma constante.

\subsection{Eficiências}

De acordo com Farrell (1957), a eficiência econômica é composta por dois componentes: técnico e alocativo. $\mathrm{O}$ técnico refere-se à capacidade de evitar desperdícios, ou seja, produzir o máximo de produtos com uma quantidade fixa de insumos e, simetricamente, produzir uma quantidade fixa de produtos usando o mínimo de insumos. O componente alocativo refere-se à habilidade de combinar insumos e produtos em proporções ótimas que fornecem o mínimo custo.

Koopmans (1951) forneceu uma definição formal da eficiência técnica: um produtor é tecnicamente eficiente se um aumento em qualquer produto requerer uma redução, no mínimo, em um dos outros produtos ou um aumento de um insumo, e se uma redução em qualquer insumo necessitar de um aumento em, no mínimo, um outro insumo ou uma redução em um produto. Uma definição formal é ilustrada por Kebede (2001):

$$
\left(x^{\prime}, y^{\prime}\right) \in I \text { para }\left(x^{\prime}, y^{\prime}\right) \#(x, y) \text { com } x^{\prime} \leq x \text { e } y^{\prime} \geq y \text {. }
$$


Farrell (1957) definiu a eficiência técnica como sendo um menos a redução proporcional máxima em todos os insumos que ainda continuam produzindo um dado produto. Com isso, um indicador menor do que um fornecerá informações de ineficiência técnica.

$\mathrm{Na}$ Figura 12, o produtor A utiliza dois insumos para produzir apenas um produto. A curva SS'representa a isoquanta estimada da eficiência com a tecnologia disponível. O ponto $\mathrm{B}$ sobre a isoquanta representa a eficiência referida da observação A. A eficiência técnica de uma unidade produtora operando no lócus A é mais comumente medida pela razão:

$$
\mathrm{TE}=0 \mathrm{~B} / 0 \mathrm{~A}
$$

a qual é igual a um menos $B A / 0 B$, levando a valores entre zero e um, e, portanto, indicando o grau de ineficiência técnica da unidade produtora. $\mathrm{O}$ valor um indicará que a firma é inteiramente eficiente tecnicamente, tal como a unidade produtora situada sobre o ponto B que está sobre a isoquanta eficiente.

Se a razão dos preços, representada pela inclinação da linha de isocusto, WW' na Figura 12 é conhecida, pode-se calcular a eficiência alocativa. A eficiência alocativa de uma unidade produtora operando no ponto A é definida pela razão:

$$
\mathrm{AE}=0 \mathrm{C} / 0 \mathrm{~B}
$$

Assim, a distância CB representa a redução no custo de produção que ocorrerá se a produção acontecer alocativamente eficiente no ponto E. Diante disso, a unidade produtora é tecnicamente eficiente, mas alocativamente ineficiente no ponto $\mathrm{B}$.

A eficiência econômica é definida como a razão:

$$
\mathrm{EE}=0 \mathrm{C} / 0 \mathrm{~A}
$$

em que a distância CA pode ser interpretada em termos de uma redução de custos. 
Observe que o produto da eficiência técnica pela alocativa fornece a medida de eficiência econômica.

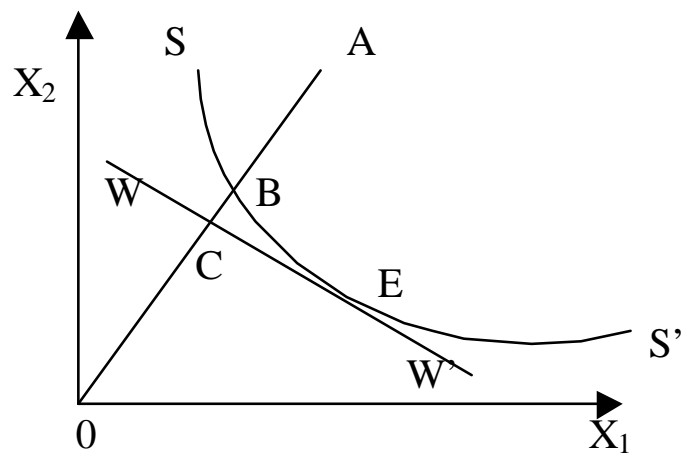

Figura 12 - Ponto de eficiência.

Fonte: Kebede (2001)

Analisaram-se até agora as possíveis combinações de insumos que produzem uma quantidade de produto, ou seja, manteve-se a quantidade de produto fixo e variaram-se os insumos. Pode-se fazer a análise mantendo as quantidades de insumos fixa e variando a quantidade de produtos até chegar a um valor que maximiza o produto dados os insumos disponíveis.

Segundo Coelli (1996), a diferença entre essas duas óticas pode ser ilustrada num exemplo de um produto e de um insumo.

$\mathrm{Na}$ Figura 13 a, tem-se a representação de uma tecnologia com retornos decrescentes à escala $f(x)$ e uma firma ineficiente operando no ponto P. A ótica dos insumos proposta por Farrell (1957) mede a eficiência técnica pela razão AB/AP enquanto que, pela ótica do produto, a eficiência técnica seria igual à razão $\mathrm{CP} / \mathrm{CD}$. Assim, as óticas do insumo e do produto só fornecerão resultados iguais de eficiência técnica quando existirem retornos constantes à escala, sendo diferentes na presença de retornos variáveis à escala (Fare \& Lovell, 1978).

$\mathrm{Na}$ Figura 13b, temos retornos constantes à escala e observa-se que $\mathrm{AB} / \mathrm{AP}=\mathrm{CP} / \mathrm{CD}$ para qualquer ponto ineficiente escolhido. Assim, com a presença de 
retornos constantes à escala, pode-se representar a curva de possibilidade de produção em duas dimensões.

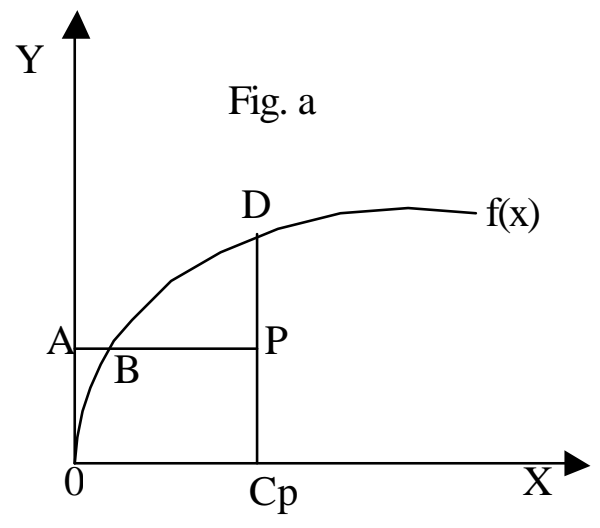

Retornos variáveis à escala

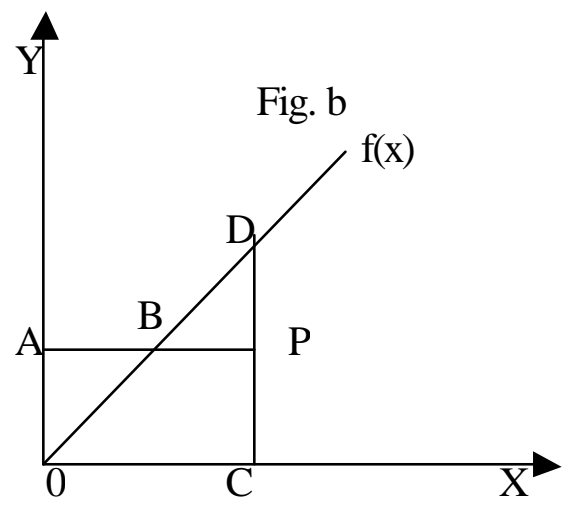

Retornos constantes à escala

Figura 13 - Medidas de eficiência técnica e retornos à escala.

Fonte: Coelli (1996)

\subsection{Técnicas de medidas de eficiência}

As várias aproximações feitas para analisar a eficiência produtiva têm utilizado paralelamente dois métodos tradicionais: paramétricos e não-paramétricos.

O método paramétrico usa o procedimento econométrico para desenvolver modelos de fronteiras estocásticas baseados nos parâmetros da fronteira determinística (Aigner \& Chu, 1968). A análise de fronteira estocástica indica os erros aleatórios associados à fronteira de produção estimada. No caso de um produto e múltiplos insumos, o produto proveniente da combinação de insumos possui uma relação funcional denotada como $y_{i}=f\left(x_{i}, \beta\right)+\varepsilon_{i}$, em que "i" representa a i-ésima unidade produtora avaliada e $\beta^{\prime} s$ são parâmetros a serem estimados. O resíduo $\varepsilon_{i}$ é composto por um erro aleatório $v_{i}$ e um componente de ineficiência $u_{i}$. Assim, quando se assume que $v_{i}=0$, a análise de fronteira estocástica se reduz a uma análise de fronteira 
determinística; e se assumir-se que $u_{i}=0$, a análise de fronteira estocástica será reduzida a uma análise de tendência central.

O método de aproximação não-paramétrica ou programação matemática tem sido usado na análise Data Envelopment Analysis (DEA) com tecnologias de produção que utilizam múltiplos insumos e produtos. Essa metodologia foi inicialmente proposta por Charnes et al. (1978), sendo conhecida como modelo CCR. As aplicações operacionais do DEA servem para construir fronteiras de produção lineares particionadas. A especificação da forma funcional da fronteira de produção não é requerida nesse método. O DEA estuda o comportamento da fronteira eficiente e a distância das unidades produtoras a fronteira de produção. Os modelos DEA básicos são determinísticos, porém recentemente tem sido incorporada alguma característica estocástica.

\subsection{Procedimentos econométricos para me dir a eficiência}

O modelo econométrico pode ser padronizado de acordo com o tipo de dado utilizado, ou seja, cortes seccionais ou dados de painel. Na seqüência da discussão, assume-se que os dados empregados são de cortes seccionais com quantidades de $\mathrm{K}$ insumos disponíveis para os $\mathrm{N}$ produtores produzindo apenas um produto final. $\mathrm{O}$ modelo de fronteira de produção pode ser escrito como:

$$
y_{i}=f\left(x_{i} ; \beta\right) \cdot E T_{i},
$$

em que $y_{i}$ é um produto escalar do produtor $i, i=1, \ldots, N, x_{i}$ é um vetor de $\mathrm{K}$ insumos usados pelo produtor $i, f\left(x_{i} ; \beta\right)$ é a fronteira de produção, $\beta$ é um vetor de parâmetros tecnológicos a serem estimados, e $E T_{i}$ é a eficiência técnica do produtor $i$.

A função fronteira de produção paramétrica é caracterizada por uma forma lisa, contínua, continuamente diferenciável e quase côncava. A fronteira está limitada por uma escala de produção potencial. Assim, tem-se: 


$$
E T=\frac{y_{i}}{f\left(x_{i} ; \beta\right)}
$$

o qual define a eficiência técnica como a razão do produto observado pelo máximo produto produzido usando a tecnologia corrente. Diante disso, $y_{i}$ encontra seu valor máximo de $f\left(x_{i} ; \beta\right)$ se, e somente se, $E T_{i}=1$. A distância pela qual uma observação se encontra abaixo da fronteira é chamada de ineficiência, ocorrendo quando $E T_{i}<1$.

O modelo econométrico é classificado como fronteira determinística ou fronteira estocástica de acordo com as pressuposições sobre o erro aleatório e como a ineficiência é definida. A fronteira de produção $f\left(x_{i} ; \boldsymbol{\beta}\right)$ descrita na equação $y_{i}=f\left(x_{i} ; \boldsymbol{\beta}\right) \cdot E T_{i}$ é determinística. Portanto, a diferença encontrada entre o produto observado $y_{i}$ pela máxima capacidade de produção $f\left(x_{i} ; \beta\right)$ se atribui inteiramente à ineficiência técnica. Segundo F $\phi$ rsund et al. (1980), a fronteira determinística possui fatores fora de controle da unidade produtora, como clima e incertezas de mercado. Qualquer erro ou imperfeição na especificação do modelo se traduzem no aumento da medida de ineficiência, o que pode não ser razoável.

A mais realística interpretação é que qualquer produtor enfrenta sua própria fronteira de produção, e qualquer fronteira possui erros aleatórios que podem estar fora do controle do produtor. Entretanto, a fronteira de produção estocástica incorpora esses choques aleatórios dentro da análise. Isso é denotado como

$$
y_{i}=f\left(x_{i} ; \boldsymbol{\beta}\right) \exp \left\{v_{i}\right\} E T
$$

em que $\left[f\left(x_{i} ; \beta\right) \exp \left\{v_{i}\right\}\right]$ é a fronteira de produção estocástica. Assim, define-se a eficiência técnica como

$$
E T=\frac{y_{i}}{f\left(x_{i} ; \beta\right) \exp \left\{v_{i}\right\}},
$$


obtida pela razão do produto observado pelo máximo de produto num ambiente caracterizado pelo $\exp \left\{v_{i}\right\}$. Nesse caso, $y_{i}$ encontrará a quantidade máxima de $\left[f\left(x_{i} ; \beta\right) \exp \left\{v_{i}\right\}\right]$ se, e somente se, $E T_{i}=1$. Contrariamente, $E T_{i}<1$ fornece uma medida de ineficiência técnica proveniente de elementos estocásticos que variam entre as unidades produtoras.

Os modelos de fronteira determinística e/ou de fronteira estocástica podem ser usados para estimar a eficiência técnica. $\mathrm{O}$ desenvolvimento da metodologia econométrica possui dois estágios distintos. Nas primeiras aplicações, tentou-se criar um modelo especificado para confrontar com a teoria existente. Nas correntes terminologias, essa especificação tem sido denotada como fronteira determinística. O segundo estágio traz uma maior flexibilidade para as especificações dos modelos de fronteira, as fronteiras estocásticas. $\mathrm{O}$ modelo de fronteiras estocásticas é o foco principal desse estudo.

\subsection{Fronteiras de produção estocásticas}

A fronteira de produção estocástica desenvolvida por Aigner et al. (1977), Battese \& Corra (1977) e Meeusen \& Van Den Broeck (1977) possuía como motivação a idéia de que o mecanismo da fronteira de produção pode não estar inteiramente sob o controle da unidade produtora estudada. Esse modelo deduziu a ineficiência técnica, mas acusou que os choques aleatórios fora de controle da unidade produtora podem afetar o produto. A principal virtude do modelo de fronteira estocástica é que esses efeitos podem ser separados da variação na eficiência técnica.

Uma formulação apropriada de uma fronteira de produção estocástica em termos de uma forma funcional geral é

$$
y_{i}=f\left(x_{i}, \beta\right)+v_{i}-u_{i}=f\left(x_{i}, \beta\right)+\varepsilon_{i},
$$

em que $v_{i}$ é componente de erro aleatório e $u_{i}$ é o componente de ineficiência técnica. 
O termo de erro aleatório $v_{i}$ é assumido ser independente e identicamente distribuído (i.i.d) com distribuição meio normal, e independente de $u_{i}$. Assim, o termo de erro $\varepsilon_{i}=v_{i}-u_{i}$ é não simétrico, desde que $u_{i} \geq 0$.

Assumindo que $v_{i}$ e $u_{i}$ sejam independentemente distribuídos de $x_{i}$ a estimação da equação (9) por Mínimos Quadrados Ordinários (MQO) fornece estimadores consistentes dos parâmetros exceto $\beta_{0}$, desde que $E\left(\varepsilon_{i}\right)=-E\left(u_{i}\right) \leq 0$. Além disso, o MQO não fornece estimativas de eficiência técnica específica. Além de obter estimativas dos parâmetros da tecnologia de produção $\beta$ em $f\left(x_{i}, \beta\right)$, a ineficiência técnica específica $u_{i}$ é o objetivo final da estimação. Para encontrar isso, é necessário que os estimadores de erro estatístico $v_{i}$ e ineficiência técnica $u_{i}$ sejam extraídos das estimações de $\varepsilon_{i}$ para cada produtor. Isso necessita de pressuposições distribucionais dos dois componentes de erro.

Entretanto, esse problema é solucionado com a estimação dos parâmetros por Máxima Verossimilhança. A estimação fornece estimadores consistentes dos $\beta^{\prime} s$ e parâmetros da variância $\sigma^{2}=\sigma_{v}^{2}+\sigma_{u}^{2}$ e $\gamma=\sigma_{u}^{2} / \sigma^{2}$, em que o parâmetro $\gamma$ tem um valor entre zero e um, sendo $\sigma^{2}$ a variância de $\varepsilon, \sigma_{v}^{2}$ a variância do termo de erro exógeno e $\sigma_{u}^{2}$ é a variância do erro sobre controle da unidade produtora. Dado $\gamma$, testase a hipótese nula de que os efeitos da ineficiência técnica não são aleatórios.

\subsection{Forma estrutural da fronteira de lucro estocástica}

As funções de produção têm sido tradicionalmente usadas para examinar a eficiência das unidades produtivas. A aproximação captura as ineficiências associadas com diferentes fatores endógenos e preços de insumos e produtos entre as firmas.

Lau \& Yotopoulus (1971) popularizaram o uso das funções de lucro, em que os preços e o nível de fatores fixos são incorporados à análise da eficiência como argumentos. A vantagem da utilização dessa aproximação é que os preços dos insumos e 
dos produtos são tratados como exógenos na tomada de decisão e podem ser usados para explicar o emprego dos insumos. Na fronteira de lucro, a eficiência é definida como a habilidade de uma firma para encontrar o máximo lucro potencial, dados os níveis de fatores fixos e os preços da firma. Exemplos recentes da aplicação incluem Ali \& Flinn (1989) e Ali \& Shah (1996). O lucro ineficiente nessa estrutura é definido como a perda de não operar sobre a fronteira.

Segundo Ali \& Flinn (1989), a curva envoltória na Figura 14 demonstra a fronteira de lucro para uma amostra de unidades produtivas, sendo uma relação entre os preços $\left(P_{i j}\right)$ e os níveis de fatores fixos $\left(Z_{k j}\right)$ que especifica a fronteira de lucro.

Cada ponto representa o lócus de lucro unitário de cada firma; pontos sobre a curva de fronteira estocástica (EMV) são unidades produtoras eficientes e todos os produtores abaixo são firmas ineficientes em termos de seus recursos específicos.

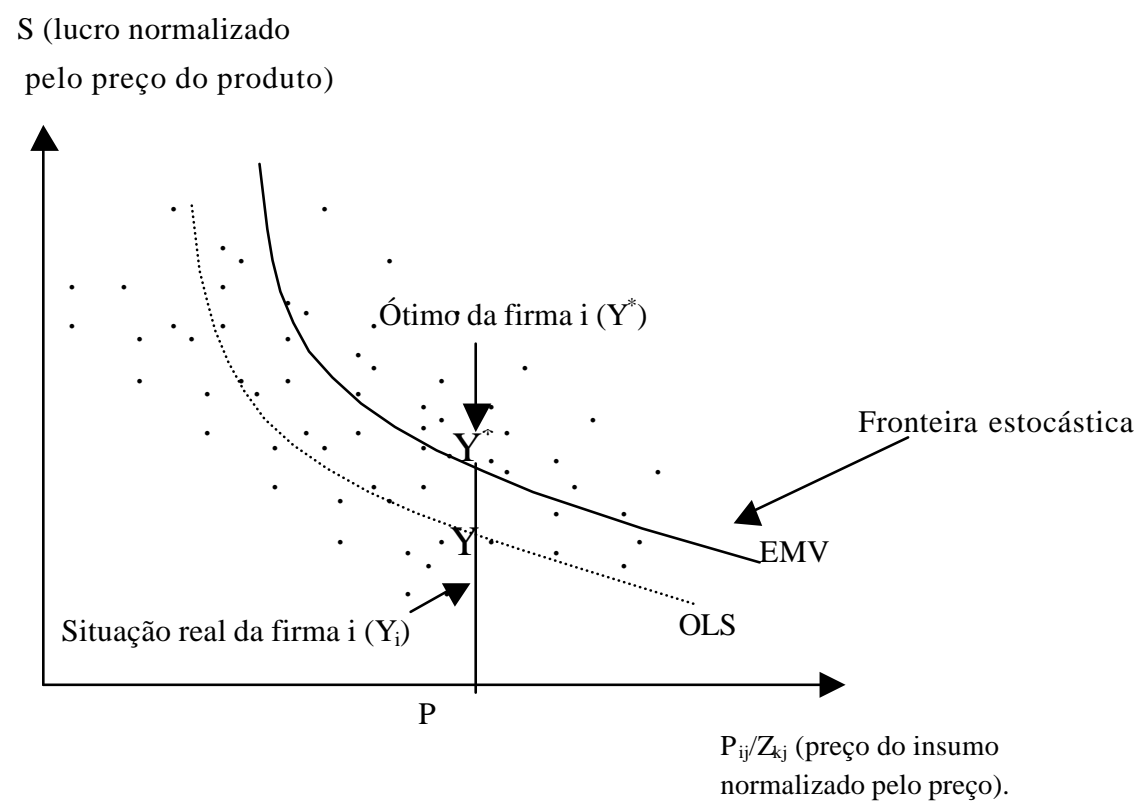

Figura 14 - Fronteira de lucro estocástica.

Fonte: Ali \& Flinn (1989)

A metodologia utilizada busca ir além de simplesmente fazer essa determinação. Permite a investigação de quais elementos contribuem para explicar a relativa eficiência 
para grandes e pequenos produtores. Produtores individuais podem estar abaixo da fronteira de lucro por outras razões do que apenas eficiência técnica e alocativa, como as barreiras de custos de transação ou as distorções que podem influenciar sua posição relativa na fronteira. Conforme Jondrow et al. (1982), Ali \& Flinn (1989) e Battese \& Coelli (1995), há uma explicação do desempenho de cada unidade produtora em termos da eficiência técnica e alocativa no primeiro estágio, e um segundo estágio explica as diferenças na eficiência em termos das diferenças específicas nos custos de transação e distorções.

A fronteira de lucro estocástica usada para estudar o lucro eficiente em um estágio é definida como:

$$
\prod_{i}=f\left(X_{i}, W_{i}, B_{j}\right) \cdot \exp \left(e_{i}\right)
$$

em que $\prod_{i}$ representa o lucro normalizado pelo preço do produto $(\mathrm{R} \$ / \mathrm{kg})$ da firma $i$, sendo definido como a receita menos custo variável, $X_{i}$ é o nível de fatores fixos utilizados para obter $\Pi_{i}$ (trabalho familiar, terra, depreciação), $W_{i}$ são os preços dos insumos específicos de cada firma normalizados pelo preço do produto $(\mathrm{R} \$ / \mathrm{kg}), \beta_{i}$ são os parâmetros desconhecidos a serem estimados e $e_{i}=v_{i}-u_{i}$ são os termos de erros.

O termo de erro $v_{i}$ é assumido ser independente e identicamente distribuído (i.i.d) com $N\left(0, \sigma_{v}^{2}\right)$ e simétrico. Assume-se que o $u_{i}$ (ineficiência) é distribuído independentemente $^{11}$ em apenas um lado (abaixo) da fronteira de lucro mostrando que de fato as unidades produtoras estão abaixo do ponto de eficiência máxima. Entretanto, as fronteiras são estimadas apenas se algumas pressuposições forem feitas sobre a distribuição do $u_{i}$ e $v_{i}$ entre as firmas e somente por técnicas de estimação não lineares, como Máxima Verossimilhança (EMV).

Battese \& Coelli (1995) utilizaram uma distribuição normal truncada $N\left(m_{i}, \boldsymbol{\sigma}_{u}^{2}\right)$,

\footnotetext{
${ }^{11}$ Assim, cada produtor possuirá diferentes funções de probabilidade.
} 
assumindo que os valores esperados dos efeitos da ineficiência específica de uma firma podem ser modelados como uma função das características entre os produtores, sendo que $m_{i}=z_{i t} \delta$ é a média da distribuição de $u_{i}, z_{i t}$ representa um vetor de variáveis que podem influenciar a eficiência da firma e $\delta$ são os parâmetros a serem estimados simultaneamente com a equação (10).

\subsection{Modelo empírico}

Segundo Coelli (1997), o passo inicial de qualquer aplicação empírica é selecionar uma forma funcional para a fronteira de produção. Existe uma gama de formas funcionais utilizadas na aplicação da análise produtiva. Entretanto, utilizar-se-á a função Cobb-Douglas, por ser flexível. De acordo com Xu \& Jeffrey (1998), ela é usada para modelar as tecnologias de produção agrícolas. A forma Cobb-Douglas tem sido utilizada em muitos estudos empíricos, particularmente na agricultura de países em desenvolvimento. Com a aproximação paramétrica, a fronteira de lucro Cobb-Douglas é especificada como

$$
\ln \prod_{i}=\beta_{0}+\beta_{i} \ln W_{i}+\delta_{i} \ln X_{i}+\varepsilon,
$$

em que i's refere-se a unidades produtoras da amostra, $\prod_{i}$ é o lucro normalizado pelo preço específico do produto, $W_{s}$ são preços dos insumos específicos normalizados pelo preço do produto, $X_{i}$ são os fatores fixos, $\beta_{i}, \delta_{i}$ são parâmetros a serem estimados e $\varepsilon_{s}$ é o termo de erro, como definido anteriormente.

A explicação econômica do procedimento de normalização das variáveis pelo preço do produto, segundo Jayne et al. (1994), garante a homogeneidade requerida pela fronteira, ou seja, impõe à restrição de retornos constantes à escala.

Os efeitos da ineficiência $\left(u_{s}^{\prime}\right)$ gerados pela equação (12) são estimados com o modelo EMV especificado como 


$$
u_{i}=\delta_{0}+\delta_{i} \ln Z_{i}+e_{i},
$$

em que $Z_{s}$ representam as variáveis que podem influenciar a ineficiência das unidades produtoras definidas na Tabela $2, \delta_{s}$ são parâmetros a ser estimados e $e_{s}$ são erros aleatórios.

Conforme Coelli et al. (1997), a metodologia usada para a estimação da fronteira de lucro estocástica pode seguir dois caminhos.

O procedimento de estimação em dois estágios, chamado de modelo 1 , em que os efeitos da ineficiência são assumidos ser independentes e identicamente distribuídos, estima primeiro a fronteira de lucro estocástica. $\mathrm{O}$ segundo passo usa os termos de erros estimados na função de lucro em função dos fatores que podem influenciar a ineficiência econômica dos produtores.

No modelo em um estágio (modelo 2), os efeitos encontrados de ineficiência são assumidos ser uma função de fatores específicos da firma, os quais implicam que eles não são identicamente distribuídos. Nesse caso, a fronteira de lucro estocástica e os efeitos da ineficiência são obtidos simultaneamente em apenas um processo de estimação.

Por se tratar de dados provenientes de cortes seccionais, espera-se a presença de alguns problemas, principalmente de multicolinearidade e simultaneidade. Entretanto, o controle desses efeitos depende de um aumento no espaço amostral, o que implicaria custos adicionais da pesquisa. Assim, considerar-se-á a possibilidade da presença dessas especificações, porém sem controlá-las. 


\section{METODOLOGIA}

\subsection{Variáveis explicativas}

O banco de dados utilizado é parte de um levantamento feito por Barros \& Zen, op. cit., p.13 em parceria com o Órgão das Nações Unidas para a Agricultura e Alimentação (FAO/ONU), que buscou identificar as principais características existentes na produção de frango de corte entre as regiões Sul e Centro-Oeste.

As variáveis utilizadas passaram por um processo de triagem que deu origem a uma gama de informações. Para medir a eficiência econômica dos produtores integrados, serão utilizados o lucro (receitas totais por lote menos custos operacionais efetivos), os preços dos insumos variáveis e os fatores fixos obtidos nas i’s propriedades.

Os dados possuem características próprias por se tratar de informações provenientes de fontes primárias de 200 produtores de frango de corte, sendo que os localizados na região Sul (região Metropolitana de Curitiba, Oeste Catarinense, Centro Oriental Rio-Grandense, Noroeste Rio-Grandense e Oeste Paranaense) totalizaram 117 produtores e na região Centro-Oeste do Brasil (Sudoeste de Mato Grosso do Sul, Sudoeste Mato-Grossense, Sudeste Mato-Grossense e Sul Goiano) somaram 83 produtores (Figura 15).

A escolha das regiões pesquisadas foi a primeira etapa do processo. Procurourse conhecer as áreas de maior produção nas duas regiões previamente definidas (Sul e Centro-Oeste) ${ }^{12}$.

\footnotetext{
${ }^{12}$ São localidades aonde a avicultura de corte se desenvolveu e/ou se está desenvolvendo com traços distintos, dando oportunidade para analisar as características de cada região.
} 
Conhecendo-as, entrou-se em contato com as agroindústrias lá estabelecidas, identificando as principais características produtivas, sociais e econômicas dos produtores integrados. A partir daí, aplicaram-se os questionários (APÊNDICE 1) aos avicultores escolhidos aleatoriamente.

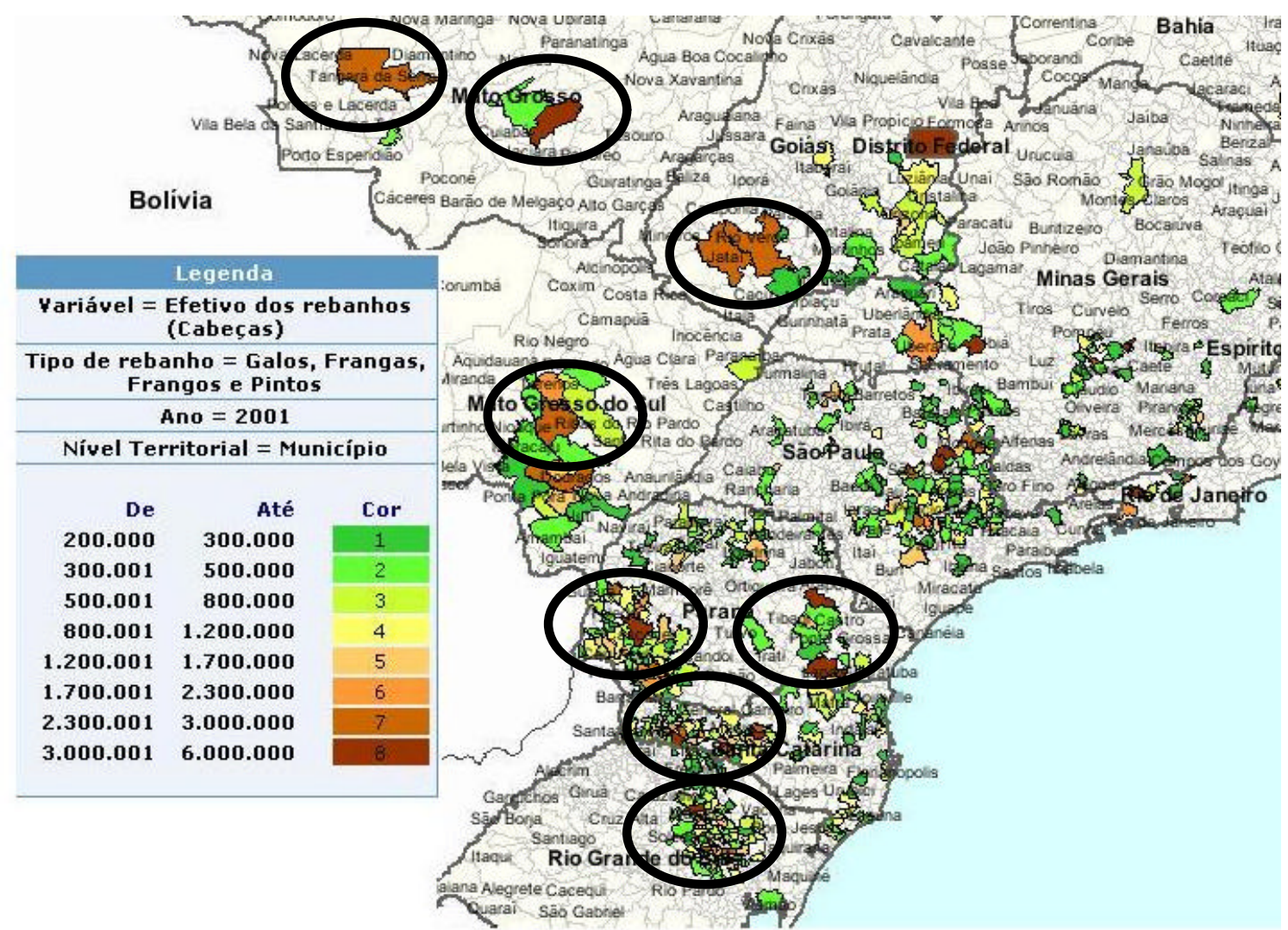

Figura 15 - Mapa das áreas selecionadas para pesquisa.

Fonte: IBGE (2001)

A função fronteira de lucro será estimada usando informações, visualizadas nas Tabelas 7 e 8 sobre a produção de frango de corte, sendo formada por variáveis explicativas que representam os preços da energia elétrica $(\mathrm{R} \$ / \mathrm{kWh})$, da mão-de-obra contratada ( $\mathrm{R} \$$ hora), da forração do piso (comumente conhecida como cama de frango) (R\$/t), do carregamento dos frangos vivos ( $\mathrm{R} \$$ frango), do aquecimento no aviário ( $\mathrm{R} \$ / \mathrm{kcal}$ ), da área de terra utilizada para a produção $\left(\mathrm{M}^{2}\right)$, do trabalho familiar (horas) e 
do capital utilizado $(\mathrm{R} \$)$.

A análise dos fatores que influenciam a ineficiência econômica será composta por uma variável que representa a tecnologia, chamada de conversão alimentar (kg ração/kg de frango vivo) e uma variável que expressa os gastos com a mitigação ambiental $(\mathrm{R} \$ / \mathrm{kg})$. Além desses, serão incluídos fatores relativos à experiência dos produtores na atividade (anos) e a idade do tomador de decisão (anos). Para analisar a concentração da produção, serão utilizadas a concentração de animais na fazenda (frangos/ha) e a escala de produção (número de frangos/lote), além de variáveis binárias para a escolaridade dos tomadores de decisão $(\mathrm{E} 1=0$ se possuir menos do que o primário completo e 1 para outros graus de escolaridade), para o local de residência do produtor ( 0 se morar fora da propriedade e 1 se residir na propriedade) e para a realização de atividades fora da propriedade ( 0 se não tiver atividades fora da propriedade e 1 se possuir atividades fora da propriedade).

A variável gasto com mitigação ambiental contempla o somatório dos custos de manipulação dos resíduos, dados por:

Mitigação ambiental $=\sum_{i=1}^{n}($ dispcama + Cleacos $t+$ Stormanure + Dispdead $)$,

sendo construída pelo somatório do dispcama (custo para a disposição dos resíduos na propriedade $(\mathrm{R} \$)$ ), Cleacost (custo de limpeza dos aviários $(\mathrm{R} \$ / \mathrm{kg})$ ), Stormanure (custo de armazenamento dos dejetos $(\mathrm{R} \$ / \mathrm{kg}$ )) e Dispdead (custo com disposição de animais mortos na propriedade $(\mathrm{R} \$ / \mathrm{kg}))$.

As Tabelas 7 e 8 também mostram as análises descritivas das variáveis utilizadas para estimar a fronteira de lucro estocástica nas regiões Sul e Centro-Oeste, respectivamente. 
Tabela 7. Análise descritiva dos dados da fronteira de lucro para a região Sul.

\begin{tabular}{|c|c|c|c|c|c|}
\hline & Variáveis & Mínimo & Média & Máximo & $\begin{array}{l}\text { Desvio- } \\
\text { Padrão }\end{array}$ \\
\hline \multicolumn{6}{|c|}{ Fronteira estocástica } \\
\hline $\mathrm{Y}$ & Lucro & 59,75 & $2.161,17$ & $6.944,48$ & $1.399,55$ \\
\hline$\beta_{1}$ & Preço da eletricidade & 0,10 & 0,15 & 0,26 & 0,02 \\
\hline$\beta_{2}$ & Preço do trabalho contratado & 0,00 & 0,19 & 6,62 & 0,76 \\
\hline$\beta_{3}$ & Preço da forração & 2,54 & 6,75 & 14,00 & 2,09 \\
\hline$\beta_{4}$ & Preço do Carregamento & 0,01 & 0,01 & 0,03 & 0,00 \\
\hline$\beta_{5}$ & Preço do aquecimento & 0,00 & 0,03 & 0,09 & 0,04 \\
\hline$\beta_{6}$ & Área ocupada & 600,00 & $1.716,24$ & $5.724,00$ & $1.114,84$ \\
\hline$\beta_{7}$ & Trabalho familiar & 0,00 & 371,23 & $1.462,92$ & 227,44 \\
\hline$\beta_{8}$ & Capital & 199,32 & 737,36 & $3.003,31$ & 471,58 \\
\hline \multicolumn{6}{|c|}{ Ineficiências } \\
\hline$\delta_{1}$ & Conversão alimentar & 1,47 & 1,85 & 2,30 & 0,15 \\
\hline$\delta_{2}$ & Gasto com mitigação ambiental & 0,00 & 238,34 & $1.641,54$ & 267,15 \\
\hline$\delta_{3}$ & Concentração animal fazenda & 59,23 & $1.473,17$ & $21.072,94$ & $2.623,36$ \\
\hline$\delta_{4}$ & Escala de produção & $4.800,00$ & $17.642,85$ & $63.120,00$ & $10.602,05$ \\
\hline$\delta_{5}$ & Experiência na atividade & 1,00 & 12,43 & 46,00 & 9,27 \\
\hline$\delta_{6}$ & Escolaridade (D) & & & & \\
\hline$\delta_{7}$ & Idade do proprietário & 22,00 & 46,70 & 80,00 & 11,21 \\
\hline$\delta_{8}$ & Atividade fora da propriedade (D) & & & & \\
\hline$\delta_{9}$ & Mora na propriedade (D) & & & & \\
\hline
\end{tabular}

Fonte: Barros \& Zen, op. cit., p.13.

Para a estimação das funções de fronteira, será utilizada a aproximação paramétrica no formato da função Log-linear Cobb-Douglas. Os coeficientes serão obtidos com o uso dos Estimadores de Máxima Verossimilhança (EMV) por meio do auxílio do pacote estatístico FRONTIER 4.1 (Coelli, 1994). 
Tabela 8. Análise descritiva dos dados da fronteira de lucro para a região Centro-Oeste.

\begin{tabular}{|c|c|c|c|c|c|}
\hline & Variáveis & Mínimo & Média & Máximo & $\begin{array}{l}\text { Desvio- } \\
\text { Padrão }\end{array}$ \\
\hline \multicolumn{6}{|c|}{ Fronteira estocástica } \\
\hline Y & Lucro & 864,06 & 6851,39 & 26264,84 & 5936,83 \\
\hline$\beta_{1}$ & Preço da eletricidade & 0,14 & 0,18 & 0,26 & 0,02 \\
\hline$\beta_{2}$ & Preço do trabalho contratado & 0,00 & 1,59 & 9,34 & 2,06 \\
\hline$\beta_{3}$ & Preço da forração & 6,41 & 41,07 & 100,00 & 22,37 \\
\hline$\beta_{4}$ & Preço Carregamento & 0,01 & 0,02 & 0,03 & 0,00 \\
\hline$\beta_{5}$ & Preço do aquecimento & 0,00 & 0,05 & 0,12 & 0,04 \\
\hline$\beta_{6}$ & Área ocupada & $1.200,00$ & $3.606,11$ & $19.200,00$ & $2.986,81$ \\
\hline$\beta_{7}$ & Trabalho familiar & 0,00 & 363,90 & $2.070,00$ & 394,92 \\
\hline$\beta_{8}$ & Capital & 417,74 & $2.233,63$ & $10.320,10$ & $1.984,19$ \\
\hline \multicolumn{6}{|c|}{ Ineficiências } \\
\hline$\delta_{1}$ & Conversão alimentar & 1,75 & 1,90 & 2,14 & 0,08 \\
\hline$\delta_{2}$ & Gasto com mitigação ambiental & 0,00 & 382,63 & 2607,00 & 522,39 \\
\hline$\delta_{3}$ & Concentração animal fazenda & 10,36 & $1.268,78$ & $15.920,77$ & $2.060,41$ \\
\hline$\delta_{4}$ & Escala de produção & $10.258,00$ & $41.537,23$ & $144.486,00$ & $31.187,00$ \\
\hline$\delta_{5}$ & Experiência na atividade & 0,50 & 6,26 & 22,00 & 4,22 \\
\hline$\delta_{6}$ & Escolaridade (D) & & & & \\
\hline$\delta_{7}$ & Idade do proprietário & 23,00 & 46,07 & 66,00 & 10,08 \\
\hline$\delta_{8}$ & Atividade fora propriedade (D) & & & & \\
\hline$\delta_{9}$ & Mora na propriedade (D) & & & & \\
\hline
\end{tabular}

Fonte: Barros \& Zen, op. cit., p.13. 


\section{RESULTADOS E DISCUSSÃO}

\subsection{Região Sul}

A estimação da fronteira de lucro estocástica foi realizada utilizando-se o modelo conhecido como $\log$-log ou $\log$-linear ${ }^{13}$, que é uma aproximação de uma função bem comportada conhecida como Cobb-Douglas. Os resultados são apresentados em termos da estimação da função lucro, da eficiência específica e dos efeitos determinantes da ineficiência econômica.

A fronteira de lucro obtida para a região Sul (Tabela 9), por intermédio do Estimador de Máxima Verossimilhança (EMV), fornece coeficientes consistentes. O teste estatístico de Máxima Verossimilhança para os efeitos da ineficiência econômica é de $-44,628$ e, baseado no teste (Likelihood-Ratio Test) LR $=52,879$, percebe-se que o valor LR excede o valor crítico obtido na tabela em Kodde \& Palm (1986). Dessa forma, pode-se inferir que a aproximação de fronteira estocástica é estatisticamente diferente da realizada por Mínimos Quadrados Ordinários (MQO), na qual os efeitos da eficiência na função fronteira são considerados independentemente distribuídos. Portanto, a hipótese nula da ausência dos efeitos de ineficiência é rejeitada, levando a acreditar que os efeitos podem estar presentes no modelo.Testa-se a hipótese de que o coeficiente gama $(\gamma)$ seja igual a zero para inferir sobre $\sigma_{u}^{2}$. Se essa variância for zero, pode-se eliminar o termo de erro $u_{i}$ e, assim, obtêm-se coeficientes que podem ser consistentemente estimados por MQO. Observa-se que gama $(\gamma)$ estimado é de 0.955 , sendo, portanto, diferente de

\footnotetext{
${ }^{13}$ Segundo Gujarati (2000), uma característica atraente do modelo log-log é que os coeficientes $\beta_{\mathrm{i}}$ medem a elasticidade da variável dependente com relação à explicativa, ou seja, a variação percentual em y para uma dada variação em $x$.
} 
zero (erro-padrão $=0,021)$. Entretanto, vê-se também que o verdadeiro gama $(\gamma)$ não é significativamente diferente de um, o qual indica que o modelo de fronteira estocástica pode não ser significativamente diferente da fronteira determinística, na qual não existem erros aleatórios na função lucro. $\mathrm{O}$ número de observações usadas no modelo foi 117, resultando uma eficiência média para os produtores de frango de corte da região Sul de 0,737 .

Alguns dos coeficientes estimados apresentaram sinais inesperados. Como exemplo, tem-se o preço do carregamento do frango $\left.\beta_{4}\right)$ e o preço de aquecimento $\left(\beta_{5}\right)$. Esses resultados indicam a tendência de aumento nos lucros com o acréscimo desses preços. Contudo, ambos não são estatisticamente significativos.

Os preços dos demais insumos, apesar de seus coeficientes não serem significativos, aparecem com seus sinais esperados. A exceção é o preço da mão-de-obra contratada $\left(\beta_{2}\right)$, cujo coeficiente é estatisticamente significativo a $10 \%$, sugerindo que o aumento de $1 \%$ no seu preço está associado à redução em $0,022 \%$ no lucro. A utilização de trabalho contratado na atividade avícola reduz os rendimentos do proprietário, visto que a atividade é intensiva em mão-de-obra familiar. Diante disso, há indícios que podem auxiliar no entendimento de por que a região Sul preza pela utilização de mãode-obra familiar na maioria de suas propriedades.

Entretanto, o trabalho familiar $\left(\beta_{7}\right)$, principal forma de mão-de-obra da região, possui indicações de interferência negativa nos lucros dos produtores, porém essa variável apresentou coeficiente não significativo.

O coeficiente da área ocupada com o galpão, representado por $\beta_{6}$, possui sinal positivo e altamente significativo. Nota-se que a atividade na região Sul pode não ter chegado ao seu limite de área, podendo ampliar mais sua produção. Lembra-se, porém, que a ambiência animal ${ }^{14}$ tem sido muito exigida pelos mercados consumidores da carne de frango. Os resultados fornecem indícios, todavia, de que a avicultura sulina pode ainda elevar suas áreas de produção sem comprometer sua lucratividade.

\footnotetext{
${ }^{14}$ A ambiência animal está relacionada com o bem-estar animal, ou seja, número de animais/m², nível de stress, maus-tratos, etc.
} 
Os investimentos em capital $\left(\beta_{8}\right)$ apresentam um coeficiente sem significância estatística. O sinal positivo indica uma elevação no lucro com o uso de mais capital. Porém, a região possui um número elevado de pequenos produtores que ficam impossibilitados de investir devido àfalta de recursos financeiros.

Tabela 9. Coeficientes obtidos para a fronteira de lucro da região Sul.

\begin{tabular}{llrrr}
\hline & \multicolumn{1}{c}{ Variáveis } & Coeficientes & Erro-Padrão & \multicolumn{1}{c}{ Teste t } \\
\hline$\beta_{0}$ & Constante & 5,144 & 0,655 & $7,849^{* * *}$ \\
$\beta_{1}$ & Preço da eletricidade & $-0,003$ & 0,197 & $-0,015$ \\
$\beta_{2}$ & Preço do trabalho & $-0,022$ & 0,012 & $-1,767^{*}$ \\
$\beta_{3}$ & Preço da forração & $-0,096$ & 0,096 & $-0,999$ \\
$\beta_{4}$ & Preço do carregamento & 0,015 & 0,113 & 0,136 \\
$\beta_{5}$ & Preço do aquecimento & 0,016 & 0,027 & 0,590 \\
$\beta_{6}$ & Área ocupada & 0,755 & 0,118 & $6,402^{* * *}$ \\
$\beta_{7}$ & Trabalho familiar & $-0,010$ & 0,012 & $-0,832$ \\
$\beta_{8}$ & Capital & 0,026 & 0,130 & 0,198 \\
$\sigma^{2}$ & Sigma Quadrado & 0,868 & 0,267 & $3,256^{* * *}$ \\
$\sigma_{\mathrm{u}}^{2}$ & Sigma Quadrado u & 0,829 & & \\
$\sigma_{\mathrm{v}}^{2}$ & Sigma Quadrado v & 0,039 & & \\
$\gamma$ & Gama & 0,955 & 0,021 & 46,442 \\
\hline
\end{tabular}

Fonte: Dados de pesquisa.

*Significante a $10 \%$

**Significante a $5 \%$

$* * *$ Significante a $1 \%$

As variáveis que podem afetar a ineficiência, descritas na Tabela 10, mostram sinais corretos em parte dos coeficientes. Entre eles, tem-se a conversão alimentar $\left(\boldsymbol{\delta}_{1}\right)$, os gastos com mitigação ambiental $\left(\boldsymbol{\delta}_{2}\right)$, a escala de produção $\left(\boldsymbol{\delta}_{4}\right)$, a escolaridade $\left(\boldsymbol{\delta}_{6}\right)$ e a idade do proprietário $\left(\delta_{7}\right)$.

A conversão alimentar, cujo coeficiente é representado por $\delta_{1}$, possui um alto 
grau de influência sobre a eficiência do produtor rural, mesmo porque todos os cálculos do rendimento do lote são realizados com esse indicador. Assim, esperava-se que uma menor conversão se transformasse em melhores retornos ao produtor, visto que a região possui experiência no controle de desperdícios de ração. $\mathrm{O}$ coeficiente estimado possui sinal negativo e é significativo em nível de $1 \%$. A indicação de que um possível aumento no índice de conversão poderia tornar o produtor mais eficiente dá informações de que o índice está eficiente e, com isso, poder-se-ia até elevar a conversão alimentar e que, mesmo assim, eles continuariam a ser eficientes. Os ganhos de produtividade sentidos pela avicultura de corte nos últimos anos partem, basicamente, das constantes quedas nos índices de conversão alimentar, favorecendo os produtores rurais. Portanto, os produtores que conseguem produzir com menores índices de conversão de insumos em carne apresentam melhor eficiência do que os demais.

Os gastos com mitigação ambiental $\left(\boldsymbol{\delta}_{2}\right)$ não fornecem resultados significativos pela estimação do modelo. Mesmo assim, o parâmetro negativo indica redução na ineficiência das unidades produtivas. De qualquer maneira, aparentemente, se houver aumentos nos custos, a avicultura brasileira não possuirá problemas sérios na área ambiental perante os graves problemas encontrados em alguns países da Europa, como Holanda e Bélgica. Uma fonte de preocupação está nos reduzidos preços dos resíduos na região Sul. O efeito da oferta e demanda sobre os resíduos está diminuindo seus preços, tendendo a zero nos próximos anos, a exemplo da suinocultura.

O coeficiente da concentração de animais $\left.\boldsymbol{\delta}_{3}\right)$ nas propriedades, apesar de não ser estatisticamente significativo nem a $10 \%$, dados os tamanhos das propriedades, basicamente inferiores a 50 ha, fornece indícios de que o aumento da concentração de frangos/ha está reduzindo a eficiência desses produtores.

O coeficiente da escala de produção $\left(\delta_{4}\right)$, embora não significativo, está indicando que o aumento do número de cabeças resultaria em maior eficiência. A nãosignificância do coeficiente sugere que a eficiência dos produtores não está sendo afetada pelas escalas de produção. A alternativa seria investir em ganhos de produtividade para competir com as demais regiões produtoras do Brasil.

A experiência dos produtores na atividade $\left(\delta_{5}\right)$ fornece indicação contrária 
(coeficiente com sinal positivo) da que se esperava, porém não sendo estatisticamente significativa. Esse resultado sugere que o tempo de experiência não contribui para os produtores serem mais eficientes.

O sinal positivo do coeficiente $\left(\boldsymbol{\delta}_{7}\right)$, apesar de não significativo, é ainda compatível com a hipótese de que os produtores mais jovens são mais eficientes.

O nível de escolaridade $\left(\delta_{6}\right)$, com coeficiente negativo e significativo a $5 \%$, sinaliza a existência de maior eficiência para os produtores com maiores níveis de escolaridade (maior ou igual ao primário completo). Os índices de educação para a população rural dessa região são baixos, e como pessoas com maiores escolaridade conseguem obter melhores resultados, investimentos em educação são recomendáveis na região.

Tabela 10. Coeficientes obtidos para os efeitos da ineficiência econômica da região Sul.

\begin{tabular}{llrrr}
\hline \multicolumn{1}{c}{ Variáveis } & Coeficientes & Erro-Padrão & \multicolumn{1}{c}{ Teste t } \\
\hline$\delta_{0}$ & Constante & $-0,288$ & 1,130 & $-0,255$ \\
$\delta_{1}$ & Conversão alimentar & $-9,407$ & 3,780 & $-2,488^{* * *}$ \\
$\delta_{2}$ & Gasto com mitigação ambiental & $-0,019$ & 0,116 & $-0,163$ \\
$\delta_{3}$ & Concentração de animal na fazenda & 0,383 & 0,234 & $1,635^{*}$ \\
$\delta_{4}$ & Escala de produção & $-0,379$ & 0,464 & $-0,817$ \\
$\delta_{5}$ & Experiência na atividade & 0,108 & 0,171 & 0,628 \\
$\delta_{6}$ & Escolaridade (D) & $-1,064$ & 0,577 & $-1,845^{*}$ \\
$\delta_{7}$ & Idade do proprietário & 0,464 & 0,750 & 0,619 \\
$\delta_{8}$ & Atividade fora da propriedade (D) & 0,206 & 0,521 & 0,395 \\
$\delta_{9}$ & Mora na propriedade (D) & 3,630 & 2,369 & 1,532 \\
\hline
\end{tabular}

Fonte: Dados de pesquisa.

*Significante a $10 \%$

**Significante a $5 \%$

*** Significante a $1 \%$

A realização de atividades fora da propriedade $\left(\delta_{8}\right)$ não está influenciando as 
medidas de eficiência, sendo o coeficiente não estatisticamente significativo. Mesmo assim, o sinal positivo indica que quem trabalha integralmente na propriedade pode possuir vantagens nos indicadores de eficiência.

O local de moradia do produtor $\left(\delta_{9}\right)$ está indicando maior eficiência para quem mora fora da propriedade. Esse resultado, mesmo com coeficiente não significativo a $10 \%$, fornece informações de que o produtor que reside fora da propriedade possui capacidade maior de administrar, ou seja, maior eficiência. Aparentemente, o que estaria influenciando seria o seu maior contato com o mundo exterior, que resulta do fato de morar fora da propriedade.

\subsection{Região Centro-Oeste}

Os coeficientes da fronteira de lucro estocástica para a região estão dispostos na Tabela 11. Os efeitos da ineficiência são medidos com o teste estatístico de Máxima Verossimilhança. O resultado de - 12,232 rejeita a hipótese nula da ausência dos efeitos de ineficiência técnica. Segundo os testes $\mathrm{LR}=36,801$, a estimação da fronteira estocástica é estatisticamente diferente em nível de $10 \%$ (valores críticos em Kodde \& Palm (1986)) da estimação realizada por MQO, no qual os efeitos da eficiência técnica da fronteira são assumidos ser independentemente distribuídos. O coeficiente gama $(\gamma)$ estimado de 0,866 é diferente de zero (erro-padrão $=0,056$ ). Entretanto, vê-se que o coeficiente gama $(\gamma)$ não é significativamente diferente de um, indicando que o modelo de fronteira estocástica não pode ser significativamente diferente da fronteira determinística, na qual não existem erros aleatórios na função lucro. $O$ número de observações usadas no modelo do Centro-Oeste foi 83, resultando numa eficiência média para os produtores de frango de corte de 0,809.

Para essa região, os coeficientes estimados em um estágio indicam alguns sinais que não eram esperados, como, por exemplo, o preço da forração $\beta_{3}$ ) e o preço do carregamento $\left(\beta_{4}\right)$, ambos não significativos.

Os demais insumos - eletricidade $\left(\beta_{1}\right)$, trabalho contratado $\left.\beta_{2}\right)$ e aquecimento 
$\left(\beta_{5}\right)$ - indicam redução no lucro com o acréscimo de seus preços. Entretanto, ambos coeficientes não são significativos.

A área de terra ocupada com a atividade incrementa o lucro. $\mathrm{O}$ efeito medido pelo coeficiente $\beta_{6}$ é significativo em nível de $10 \%$. Todavia, permanece a dúvida de quanto é a conveniência de ampliar-se a capacidade de produção dos galpões em benefício da remuneração do produtor, pois a questão de ambiência animal pode interferir nesses números.

$\mathrm{O}$ coeficiente do uso de trabalho familiar $\left(\beta_{7}\right)$ significativo a $5 \%$ está-se traduzindo em maiores índices de lucratividade. Isso sugere a possibilidade de que se poderia despender mais horas de trabalho familiar a fim de gerar maiores níveis de lucratividade para as unidades produtivas da região Centro-Oeste.

O nível de capitalização dos produtores localizados no Centro-Oeste fornece indícios de influência positiva nos lucros, sendo altamente significativo o coeficiente $\beta_{8}$. Assim, há fortes indicações de que as unidades produtoras mais capitalizadas tenderão a prosperar naquela região.

A Tabela 12 demonstra análise dos efeitos sobre a ineficiência dos produtores. $\mathrm{O}$ coeficiente da conversão alimentar $\left(\delta_{1}\right)$ foi positivo, porém não significativo. Assim, parece que, mesmo com altos investimentos em tecnologia, os produtores podem ainda não estar dominando o "know-how" de produção. Talvez um cuidado especial tenha de ser dedicado ao consumo exagerado de ração. $\mathrm{O}$ resultado está relacionado, diretamente, com a lucratividade da atividade, visto que as integradoras utilizam o índice para os cálculos da remuneração do produtor.

$\mathrm{O}$ coeficiente dos gastos com mitigação ambiental $\left(\boldsymbol{\delta}_{2}\right)$, apesar de ser não significativo, fornece indícios de aumento nos níveis de ineficiência dos produtores com o crescimento dos custos com mitigação.

A concentração de frango na propriedade, representada pelo coeficiente $\delta_{3}$, resultou em não significância estatística. Assim, dentro dos limites atuais, o grau de concentração não estaria afetando a lucratividade. 
Tabela 11. Coeficientes obtidos para a fronteira de lucro da região Centro-Oeste.

\begin{tabular}{llrrr}
\hline & \multicolumn{1}{c}{ Variáveis } & Coeficientes & \multicolumn{1}{c}{ Erro-Padrão } & \multicolumn{1}{c}{ Teste t } \\
\hline$\beta_{0}$ & Constante & 4,582 & 1,035 & $4,426^{* * *}$ \\
$\beta_{1}$ & Preço da eletricidade & $-0,071$ & 0,227 & $-0,314$ \\
$\beta_{2}$ & Preço do trabalho & $-0,004$ & 0,011 & $-0,312$ \\
$\beta_{3}$ & Preço da forração & 0,050 & 0,050 & 0,996 \\
$\beta_{4}$ & Preço do carregamento & 0,006 & 0,270 & 0,023 \\
$\beta_{5}$ & Preço do aquecimento & $-0,031$ & 0,033 & $-0,948$ \\
$\beta_{6}$ & Área ocupada & 0,272 & 0,183 & $1,482^{*}$ \\
$\beta_{7}$ & Trabalho familiar & 0,018 & 0,008 & $2,148^{* *}$ \\
$\beta_{8}$ & Capital & 0,564 & 0,177 & $3,176^{* * *}$ \\
$\sigma^{2}$ & Sigma Quadrado & 0,304 & 0,124 & $2,439 * *$ \\
$\sigma_{\mathrm{u}}^{2}$ & Sigma Quadrado u & 0,263 & & \\
$\sigma_{\mathrm{v}}^{2}$ & Sigma Quadrado v & 0,041 & & \\
$\gamma$ & Gama & 0,866 & 0,056 & $15,408^{* * * *}$ \\
\hline
\end{tabular}

Fonte: Dados de pesquisa.

*Significante a $10 \%$

$* *$ Significante a $5 \%$

***Significante a $1 \%$

O coeficiente da escala de produção $\left(\delta_{4}\right)$ sugere a existência de ganhos de escala pelos produtores localizados na região Centro-Oeste do Brasil, porém não é significativo. Não se pode confirmar, portanto, a hipótese de que um dos fatores que poderiam ter influenciado o processo de deslocamento da atividade para a região de fronteira teriam sido justamente os possíveis ganhos de escala existentes.

A experiência dos produtores $\left(\boldsymbol{\delta}_{5}\right)$ aparece como redutor da ineficiência, porém esse efeito não é significativo. Os avicultores que migraram da região Sul para o CentroOeste podem estar influenciando os resultados da forma desejada, mas não de forma significativa.

O nível elevado de educação apresentou coeficiente $\left(\boldsymbol{\delta}_{6}\right)$ positivo, mas não significativo. Resultado em parte estranho, no entanto se pensássemos que a maioria dos 
avicultores trabalha de forma integrada e que existe um "pacote" tecnológico fornecido pela agroindústria que limita o uso de conhecimentos não contidos na tecnologia utilizada pela empresa, torna-se até certo ponto compreensível esse resultado. As pessoas mais educadas podem manter um melhor gerenciamento da propriedade dentro dos limites permitidos pelo sistema.

A não-significância do coeficiente da idade dos produtores $\left(\delta_{7}\right)$ mostra que a atividade não é influenciada por essa característica dos produtores, a exemplo da experiência na atividade. Entretanto, o sinal positivo sugere a existência de melhores níveis de eficiência ligados às pessoas mais jovens.

Tabela 12. Coeficientes obtidos para os efeitos da ineficiência econômica da região Centro-Oeste.

\begin{tabular}{llrrr}
\hline & \multicolumn{1}{c}{ Variáveis } & Coeficientes & Erro-Padrão & \multicolumn{1}{c}{ Teste t } \\
\hline $\boldsymbol{\delta}_{0}$ & Constante & $-0,318$ & 1,416 & $-0,225$ \\
$\boldsymbol{\delta}_{1}$ & Conversão alimentar & 5,762 & 4,342 & 1,327 \\
$\boldsymbol{\delta}_{2}$ & Gasto com mitigação ambiental & 0,039 & 0,063 & 0,617 \\
$\boldsymbol{\delta}_{3}$ & Concentração animal na fazenda & $-0,434$ & 0,348 & $-1,247$ \\
$\boldsymbol{\delta}_{4}$ & Escala de produção & $-0,744$ & 0,493 & $-1,511$ \\
$\delta_{5}$ & Experiência na atividade & $-0,400$ & 0,642 & $-0,623$ \\
$\boldsymbol{\delta}_{6}$ & Escolaridade (D) & 1,162 & 0,720 & 1,614 \\
$\boldsymbol{\delta}_{7}$ & Idade do proprietário & 1,635 & 1,383 & 1,183 \\
$\boldsymbol{\delta}_{8}$ & Atividade fora da propriedade (D) & $-2,455$ & 1,741 & $-1,410$ \\
$\boldsymbol{\delta}_{9}$ & Mora na propriedade (D) & 0,216 & 0,349 & 0,618 \\
\hline
\end{tabular}

Fonte: Dados de pesquisa.

*Significante a $10 \%$

$* *$ Significante a $5 \%$

****Significante a $1 \%$

$\mathrm{O}$ efeito do desempenho de atividades fora das suas propriedades, medido pelo coeficiente $\delta_{8}$, foi negativo e não significativo, o que indica maior eficiência dos 
produtores com essa característica. $\mathrm{O}$ desempenho de atividades fora da fazenda parece favorecer a capacidade gerencial que os avicultores do Centro-Oeste possuem em relação aos que vivem apenas da remuneração obtida dentro da fazenda.

O coeficiente do local de moradia dos produtores $\left(\boldsymbol{\delta}_{9}\right)$ tem sinal-padrão, mas não significativo. Assim, não se pode afirmar que os que moram nas propriedades possuem um nível de ineficiência maior do que os proprietários que residem fora das suas terras, reforçando o resultado do coeficiente $\delta_{8}$, que mediu os efeitos de o produtor possuir atividade fora da propriedade.

\subsection{Brasil}

A fronteira de lucro obtida por meio do EMV fornece coeficientes consistentes. Sendo assim, o teste estatístico de Máxima Verossimilhança para os efeitos da ineficiência técnica da fronteira é de $-84,248$. O valor do teste, $L R=65,039$, excede o valor crítico (valores críticos em Kodde \& Palm (1986)). Dessa forma, pode-se inferir que a aproximação de fronteira estocástica é estatisticamente diferente da realizada por MQO, na qual os efeitos da eficiência na função fronteira são assumidos ser independentemente distribuídos. Portanto, a hipótese nula da ausência dos efeitos de ineficiência técnica é rejeitada, levando a acreditar que os efeitos podem estar presentes no modelo.

Testa-se a hipótese de que o parâmetro gama $(\gamma)$ seja igual a zero inferindo sobre a $\sigma_{u}^{2}$. Se essa variância for zero, pode-se eliminar o termo de erro $u_{i}$, e, assim, obtêm-se parâmetros que podem ser consistentemente estimados por MQO. O gama $(\gamma)$ estimado de 0,975 é claramente diferente de zero (erro-padrão $=0,015$ ). Entretanto, vêse que o verdadeiro coeficiente gama $(\gamma)$ não é significativamente diferente de um, o qual indica que o modelo de fronteira estocástica não pode ser significativamente diferente da fronteira determinística, na qual não existem erros aleatórios na função lucro. O número de observações usado no modelo foi 200, resultando numa eficiência média para os produtores de frango de corte de 0,745 . 
Os dados agregados para o Brasil fornecem algumas informações que divergem dos resultados obtidos separadamente, como se pode visualizar na Tabela 13. Nos insumos variáveis, os coeficientes dos preços da forração $\left(\beta_{3}\right)$ e do carregamento $\beta_{4}$ ) se mostram positivos. Entretanto, apenas o coeficiente do preço da forração é estatisticamente significativo a $1 \%$. De qualquer forma, tais resultados contrariam as expectativas teóricas e práticas.

Já o coeficiente do preço da eletricidade, representado por $\boldsymbol{\beta}_{1}$ ), apresenta sinal negativo e significativo. A variação encontrada nos preços entre as duas regiões, associada aos diferentes manejos utilizados, pode ser uma explicação para esse resultado.

$\mathrm{O}$ preço do aquecimento $\left(\beta_{5}\right)$ interfere negativamente no resultado das unidades produtivas. Entretanto, o coeficiente não é significativo.

O coeficiente da área ocupada com a atividade avícola $\left(\beta_{6}\right)$ é positivo e estatisticamente significativo a $1 \%$. Assim, quanto maior a área ocupada, maior será o lucro obtido da unidade produtora. Se houver um aumento de $1 \%$ na área ocupada, o lucro tende a crescer cerca de $0,52 \%$. Portanto, as áreas ocupadas com a avicultura ainda não fornecem indícios de estarem prejudicando a lucratividade.

O uso de trabalho familiar $\left(\beta_{7}\right)$, em nível de Brasil, está indicando ganhos na lucratividade com o aumento das horas trabalhas pela família. Porém, o coeficiente não resultou em significância estatística.

O capital investido, representado pelo coeficiente $\beta_{8}$, com sinal positivo e significativo a $1 \%$, demonstra que os produtores que investiram mais em sua atividade obtiveram maiores lucros: o aumento de $1 \%$ no capital investido acaba por influenciar $0,36 \%$ de aumento nos lucros.

As variáveis que podem estar afetando a ineficiência dos produtores de frango de corte nas regiões Sul e Centro-Oeste são expostas na Tabela 14.

O coeficiente da conversão alimentar $\left(\delta_{1}\right)$ apresentou-se negativo e estatisticamente significativo a $10 \%$. Dessa forma, isso sugere que há uma redução na ineficiência dos produtores quando o índice de conversão aumenta. 
Tabela 13. Coeficientes obtidos para a fronteira de lucro do Brasil.

\begin{tabular}{llrrr}
\hline & \multicolumn{1}{c}{ Variáveis } & Coeficientes & Erro-Padrão & \multicolumn{1}{c}{ Teste t } \\
\hline$\beta_{0}$ & Constante & 3,776 & 0,458 & $7,354^{* * *}$ \\
$\beta_{1}$ & Preço da eletricidade & $-0,210$ & 0,116 & $-1,836^{*}$ \\
$\beta_{2}$ & Preço do trabalho contratado & $-0,005$ & 0,008 & $-0,706$ \\
$\beta_{3}$ & Preço da forração & 0,109 & 0,035 & $3,069^{* * *}$ \\
$\beta_{4}$ & Preço do carregamento & 0,042 & 0,096 & 0,417 \\
$\beta_{5}$ & Preço do aquecimento & $-0,013$ & 0,019 & $-0,634$ \\
$\beta_{6}$ & Área ocupada & 0,636 & 0,101 & $6,070^{* * *}$ \\
$\beta_{7}$ & Trabalho familiar & 0,010 & 0,007 & 1,460 \\
$\beta_{8}$ & Capital & 0,259 & 0,092 & $2,662^{* * *}$ \\
$\sigma^{2}$ & Sigma Quadrado & 1,925 & 1,057 & $1,820^{*}$ \\
$\sigma_{\mathrm{u}}^{2}$ & Sigma Quadrado u & 1,876 & & \\
$\sigma_{\mathrm{v}}^{2}$ & Sigma Quadrado v & 0,048 & & \\
$\gamma$ & Gama & 0,975 & 0,015 & $65,048^{* * *}$ \\
\hline
\end{tabular}

Fonte: Dados de pesquisa.

*Significante a $10 \%$

** Significante a $5 \%$

****Significante a $1 \%$

$\mathrm{O}$ coeficiente do gasto com mitigação ambiental $\left(\boldsymbol{\delta}_{2}\right)$ se mostrou positivo e não significativo. Há indícios, pois, que o crescimento dos mesmos aumenta a ineficiência dos produtores. Percebe-se que a avicultura, em nível nacional, ainda não está sofrendo problemas mais sérios com a questão ambiental. Porém, deve-se estar atento a esse problema para evitar possíveis restrições comerciais com as exportações brasileiras.

A concentração animal $\left(\delta_{3}\right)$ apresenta coeficiente negativo, mas não significativo. Essa variável mostra alguns indícios de que o maior número de frango/ha está reduzindo a ineficiência dos produtores.

A maior escala de produção $\left(\delta_{4}\right)$ parece reduzir a ineficiência, contudo seu coeficiente não é estatisticamente significativo. As unidades produtoras com maiores escalas de produção fornecem indicações de possuírem menores medidas de ineficiência. 
Os resultados relacionados aos anos de experiência $\left(\delta_{5}\right)$ e à escolaridade $\left(\boldsymbol{\delta}_{6}\right)$, cujos coeficientes apresentam sinais positivos e não significativos, são surpreendentes, pois a escolaridade ou os anos ligados à atividade não estão afetando a ineficiência dos produtores. $\mathrm{O}$ fato de eles estarem integrados verticalmente pode estar impossibilitandoos de utilizar os conhecimentos adquiridos diretamente na atividade.

O coeficiente da idade dos produtores $\left(\delta_{7}\right)$ possui sinal positivo e não significativo. Assim, não é possível identificar um efeito relevante dessa variável.

As atividades fora da propriedade $\left(\boldsymbol{\delta}_{8}\right)$ apresentam coeficiente não significativo estatisticamente.

O coeficiente do local de moradia dos produtores $\left(\delta_{9}\right)$ também não foi significativo. Os resultados encontrados mostram a pouca relevância dessa variável.

Tabela 14. Coeficientes obtidos para os efeitos da ineficiência econômica do Brasil.

\begin{tabular}{llrrr}
\hline & \multicolumn{1}{c}{ Variáveis } & Coeficientes & Erro-Padrão & Teste t \\
\hline $\boldsymbol{\delta}_{0}$ & Constante & 5,863 & 5,825 & 1,007 \\
$\boldsymbol{\delta}_{1}$ & Conversão alimentar & $-16,981$ & 9,263 & $-1,833^{*}$ \\
$\boldsymbol{\delta}_{2}$ & Gasto com mitigação ambiental & 0,012 & 0,053 & 0,227 \\
$\boldsymbol{\delta}_{3}$ & Concentração animal na fazenda & $-0,505$ & 0,313 & $-1,615$ \\
$\boldsymbol{\delta}_{4}$ & Escala de produção & $-0,261$ & 0,398 & $-0,656$ \\
$\boldsymbol{\delta}_{5}$ & Experiência na atividade & 0,308 & 0,261 & 1,181 \\
$\boldsymbol{\delta}_{6}$ & Escolaridade (D) & 0,613 & 0,427 & 1,435 \\
$\boldsymbol{\delta}_{7}$ & Idade do proprietário & 0,762 & 0,517 & 1,474 \\
$\boldsymbol{\delta}_{8}$ & Atividade fora da propriedade (D) & $-2,188$ & 1,368 & $-1,599$ \\
$\boldsymbol{\delta}_{9}$ & Mora na propriedade (D) & 1,221 & 0,808 & 1,512 \\
$\boldsymbol{\delta}_{10}$ & Localização (Sul, outros) (D) & 1,661 & 0,831 & $1,998 * *$ \\
\hline
\end{tabular}

Fonte: Dados de pesquisa.

* Significante a $10 \%$

**Significante a $5 \%$

***Significante a $1 \%$ 
O coeficiente da localização dos produtores $\left(\delta_{10}\right)$, significativo a $5 \%$, indica que os localizados na região de Sul são mais ineficientes do que aqueles que residem nas áreas de fronteira. A presença de grandes produtores na região Centro-Oeste, a maior automação dos aviários e os maiores investimentos podem estar proporcionando uma maior eficiência a eles.

\subsection{Comparações entre as regiões Sul e Centro-Oeste, e o Brasil}

A análise comparativa dos coeficientes estimados para as regiões Sul e CentroOeste revela algumas características de relativa importância (ver Tabela 15).

O coeficiente do preço da eletricidade para o Brasil, representado por $\beta_{1}$, está indicando redução nos lucros com o aumento do seu preço. Para as duas regiões separadamente, não se obteve resultado significativo.

O preço da mão-de-obra contratada $\left(\beta_{2}\right)$ na região Sul é um fator que reduz a lucratividade do proprietário com o aumento do preço. Verifica-se, dessa forma, um dos possíveis fatores que contribuem para a intensificação do uso de mão-de-obra familiar nessa região (Jank, 1997). A cultura européia, predominante em boa parte da população, pode influenciar o uso desse fator. Agregando as observações, percebe-se que não existe relação significativa entre o lucro e o preço da mão-de-obra contratada.

Ao contrário da região Sul, o Centro-Oeste obtém ganhos na lucratividade com o uso de mão-de-obra familiar $\left(\beta_{7}\right)$. Como nessa região o uso da família não é muito difundido, principalmente pelas características étnicas da população, captam-se indicações de que um aumento no número de horas trabalhadas pela família poderia elevar os lucros da propriedade.

No Brasil, o coeficiente do preço da forração $\beta_{3}$ ) possui papel de aumentar a lucratividade da propriedade aparentemente via um efeito "qualidade". A necessidade de compra de insumos de boa qualidade eleva os preços da forração. Entretanto, esse preço maior é recompensado por um maior lucro.

Os coeficientes da região Sul e do Brasil indicam ganhos via ocupação da área de produção $\beta_{6}$ ), visto que o aumento da área dos galpões implica o crescimento do lucro. 
Economicamente, esse resultado possui utilidade na otimização das áreas dos aviários. Porém, existe a questão do bem-estar, que envolve muitas críticas quanto ao número de animais existentes por metro quadrado, os níveis de estresse dos frangos, etc.

Por ser área relativamente nova, o Centro-Oeste tem recebido investimentos que estão influenciando, nitidamente, o nível de lucro dos proprietários. O financiamento proveniente do FCO (Fundo Constitucional de Financiamento do Centro-Oeste - Banco do Brasil) auxiliou o desenvolvimento dessa área até então de pouca relevância para a atividade avícola. Esse fator estaria privilegiando os produtores dessa região, já que o coeficiente do capital $\left(\beta_{8}\right)$ possui sinal positivo e significativo.

O impacto desse resultado estaria sugerindo que, em nível de Brasil, o maior uso de capital estaria favorecendo a lucratividade dos produtores amostrados.

Tabela 15. Comparativo dos coeficientes estimados para a fronteira de lucro estocástica para as regiões Sul e Centro-Oeste, e para o Brasil.

\begin{tabular}{llcrc}
\hline & \multicolumn{1}{c}{ Variáveis } & $\begin{array}{c}\text { Coeficientes } \\
\text { Sul }\end{array}$ & $\begin{array}{c}\text { Coeficientes } \\
\text { Centro-Oeste }\end{array}$ & $\begin{array}{c}\text { Coeficientes } \\
\text { Brasil }\end{array}$ \\
\hline$\beta_{0}$ & Interceptor & $5,144^{* * *}$ & $4,582^{* * *}$ & $3,776^{* * *}$ \\
$\beta_{1}$ & Preço da eletricidade & $-0,003^{\mathrm{ns}}$ & $-0,071^{\mathrm{ns}}$ & $-0,210^{*}$ \\
$\beta_{2}$ & Preço do trabalho & $-0,022^{*}$ & $-0,004^{\mathrm{ns}}$ & $-0,005^{\mathrm{ns}}$ \\
$\beta_{3}$ & Preço da forração & $-0,096^{\mathrm{ns}}$ & $0,050^{\mathrm{ns}}$ & $0,109^{* * *}$ \\
$\beta_{4}$ & Preço do carregamento & $0,015^{\mathrm{ns}}$ & $0,006^{\mathrm{ns}}$ & $0,042^{\mathrm{ns}}$ \\
$\beta_{5}$ & Preço do aquecimento & $0,016^{\mathrm{ns}}$ & $-0,031^{\mathrm{ns}}$ & $-0,013^{\mathrm{ns}}$ \\
$\beta_{6}$ & Área ocupada & $0,755^{* * *}$ & $0,272^{\mathrm{ns}}$ & $0,636^{* * *}$ \\
$\beta_{7}$ & Trabalho familiar & $-0,010^{\mathrm{ns}}$ & $0,018^{* *}$ & $0,010^{\mathrm{ns}}$ \\
$\beta_{8}$ & Capital & $0,026^{\mathrm{ns}}$ & $0,564^{* * *}$ & $0,259^{* * *}$ \\
\hline
\end{tabular}

Fonte: Dados de pesquisa.

* Significante a $10 \%$

** Significante a 5\%

${ }^{* * *}$ Significante a $1 \%$

${ }^{n s}$ Não significativo 
Comparativamente, os efeitos da ineficiência são sentidos de forma diferente entre as diversas regiões (ver Tabela 16). É o caso do coeficiente $\delta_{1}$ (conversão alimentar) utilizado como sinalizador dos ganhos de produtividade. Na região Sul e em nível de Brasil, esse coeficiente está agindo para reduzir a ineficiência. A exceção está na região Centro-Oeste, onde o índice precisa ser melhorado diante dos encontrados no Sul para torná-lo fator de aumento da eficiência.

Fazendas com maior concentração de frangos/ha $\left.\delta_{3}\right)$ tendem a ser mais eficientes na região Centro-Oeste e mais ineficientes na região Sul. A possibilidade de o Sul ter problemas com a elevada concentração existente nas propriedades pode estar ligada às pequenas áreas de terra encontradas na região e que não podem ser utilizadas para a agricultura. Dessa forma, a atividade básica da fazenda torna-se a avicultura. Todos os espaços são utilizados para a produção. E, nesse caso, haveria uma excessiva alocação que poderia estar influenciando negativamente os produtores.

A produção em escala $\left(\boldsymbol{\delta}_{4}\right)$ não está demonstrando significância entre os resultados. Entretanto, os sinais refletem efeitos negativos em todas as regiões, fornecendo indícios de redução na ineficiência da atividade. Um dos fatores identificados que levaram a avicultura a se deslocar da região Sul para o Centro-Oeste teria sido a possibilidade de produzir em grandes escalas. Não foram, entretanto, encontradas evidências sólidas nesse sentido.

Os índices de escolaridade, representados pelo coeficiente $\delta_{6}$, captados junto aos tomadores de decisão, indicam que os produtores da região Sul, que possuem menos do que primário completo, são os produtores mais ineficientes, e, de forma inversa, o produtor com maior nível de escolaridade é mais eficiente. Esse resultado é similar aos encontrados por Duraisamy (1988) ao analisar os efeitos da educação na produção agrícola da Índia, por Abdulai \& Huffman (1998) ao examinar o lucro ineficiente dos produtores de arroz no norte de Gana, e por Ali e Flinn (1989) estudando o lucro eficiente dos produtores de arroz do Paquistão. A questão cultural pode estar influenciando os produtores da região Sul a obterem resultados tão expressivos.

Já para o Centro-Oeste, isso se inverte, pois os avicultores com menos do que oito anos de escola são os produtores mais eficientes, deixando os com maior grau de 
educação com menores medidas de eficiência. Entretanto, não seria tão errado supor que o sistema de produção em que está inserida a maioria dos produtores brasileiros pode influenciar significativamente esse resultado. Muitas vezes, o efeito de um nível elevado de educação influencia pouco as técnicas impostas pela agroindústria dado que é ela quem fornece o "pacote" tecnológico do qual não se pode divergir. Sharma et al. (1999) chegaram a resultados semelhantes para a educação em seus estudos com a eficiência técnica, alocativa e econômica dos produtores de suínos do Hawaí, identificando que o maior nível de educação dos produtores afetava positivamente a ineficiência. Entretanto, o coeficiente não possuía significância estatística.

Nenhuma das regiões apresentou significância para o coeficiente $\left(\delta_{7}\right)$ relativo a idade dos proprietários. Os jovens tomadores de decisão, em geral, são considerados mais propensos a mudanças na estrutura organizacional e produtiva das propriedades, administrando a atividade de forma mais empreendedora. Abdulai \& Huffman (1998), estudando a ineficiência do lucro nas propriedades de arroz do norte de Gana, identificaram que os produtores mais jovens tendem a obter melhores índices de eficiência. Embora o sinal $\left(\delta_{7}\right)$ seja condizente com essa observação, a sua nãosignificância impede que se chegue à mesma conclusão.

A manutenção de atividades fora da propriedade $\left(\delta_{8}\right)$, em nível de Brasil e Centro-Oeste, embora com sinal sugerindo menores ineficiências perante os que apenas usam os recursos da propriedade como fonte de renda, não apresenta significância estatística.

O local de moradia dos produtores, representado pelo coeficiente $\delta_{9}$, não tem influenciado os produtores das regiões pesquisadas. Eles apresentam maiores níveis de ineficiência quando residem na propriedade, porém sem significância.

A inclusão de uma variável binária da regressão agregada para o Brasil comprovou diferença estatisticamente significativa entre as duas regiões. Nesse caso, os resultados encontrados indicam que os produtores no Sul, considerado mais tradicionais, são mais ineficientes do que os localizados no Centro-Oeste.

A distribuição de freqüência das medidas de eficiência econômica estimada para os produtores de frango de corte das regiões Sul e Centro-Oeste está disposta na Figura 
16. Os níveis de eficiência verificados para as unidades produtivas localizadas na região Sul estão mais dispersos do que os verificados no Centro-Oeste, obtendo média de $73,7 \%$ de eficiência. Há produtores com medidas entre todos os intervalos. O intervalo de $80 \% \mid---100 \%$ de eficiência econômica possui a maior concentração de propriedades, representando $44 \%$ da amostra sulina. A faixa de $60 \%$--- $80 \%$ de eficiência possui $36,7 \%$ das unidades produtivas dessa região. Os demais intervalos representam apenas $19,3 \%$ dos produtores amostrados.

Tabela 16. Efeitos da ineficiência sobre as diferentes regiões analisadas.

\begin{tabular}{llrrr}
\hline & \multicolumn{1}{c}{ Variáveis } & $\begin{array}{c}\text { Coeficientes } \\
\text { Sul }\end{array}$ & $\begin{array}{r}\text { Coeficientes } \\
\text { Centro-Oeste }\end{array}$ & $\begin{array}{r}\text { Coeficientes } \\
\text { Brasil }\end{array}$ \\
\hline$\delta_{0}$ & Constante & $-0,288^{\mathrm{ns}}$ & $-0,318^{\mathrm{ns}}$ & $5,863^{\mathrm{ns}}$ \\
$\boldsymbol{\delta}_{1}$ & Conversão alimentar & $-9,407^{* *}$ & $5,762^{\mathrm{ns}}$ & $-16,981^{*}$ \\
$\boldsymbol{\delta}_{2}$ & Gasto com mitigação ambiental & $-0,019^{\mathrm{ns}}$ & $0,039^{\mathrm{ns}}$ & $0,012^{\mathrm{ns}}$ \\
$\boldsymbol{\delta}_{3}$ & Concentração animal na fazenda & $0,383^{*}$ & $-0,434^{\mathrm{ns}}$ & $-0,505^{\mathrm{ns}}$ \\
$\delta_{4}$ & Escala de produção & $-0,379^{\mathrm{ns}}$ & $-0,744^{\mathrm{ns}}$ & $-0,261^{\mathrm{ns}}$ \\
$\boldsymbol{\delta}_{5}$ & Experiência na atividade & $0,108^{\mathrm{ns}}$ & $-0,400^{\mathrm{ns}}$ & $0,308^{\mathrm{ns}}$ \\
$\boldsymbol{\delta}_{6}$ & Escolaridade (D) & $-1,064^{*}$ & $1,162^{\mathrm{ns}}$ & $0,613^{\mathrm{ns}}$ \\
$\boldsymbol{\delta}_{7}$ & Idade do proprietário & $0,464^{\mathrm{ns}}$ & $1,635^{\mathrm{ns}}$ & $0,762^{\mathrm{ns}}$ \\
$\boldsymbol{\delta}_{8}$ & Atividade fora da propriedade (D) & $0,206^{\mathrm{ns}}$ & $-2,455^{\mathrm{ns}}$ & $-2,188^{\mathrm{ns}}$ \\
$\boldsymbol{\delta}_{9}$ & Mora na propriedade (D) & $3,630^{\mathrm{ns}}$ & $0,216^{\mathrm{ns}}$ & $1,221^{\mathrm{ns}}$ \\
$\boldsymbol{\delta}_{10}$ & Dummy localização (D) & & & $1,661^{* *}$ \\
\hline
\end{tabular}

Fonte: Dados de pesquisa.

*Significante a $10 \%$

${ }^{* *}$ Significante a $5 \%$

${ }^{* * * *}$ Significante a $1 \%$

${ }^{n s}$ Não significativo

O elevado índice observado na Figura 16 demonstra a superioridade da eficiência econômica das unidades produtivas da região Centro-Oeste. Essa localidade possui seus níveis de eficiência média em torno de $80,9 \%$, sendo que a maior concentração de 
produtores está localizada no intervalo entre $80 \%$ e $100 \%$ de eficiência econômica. Essa faixa representa $74,7 \%$ dos produtores amostrados para essa região. Na seqüência, têmse $14,5 \%$ da amostra para o estrato entre $60 \%$--- $80 \%$ e 10,8\% para os demais intervalos.

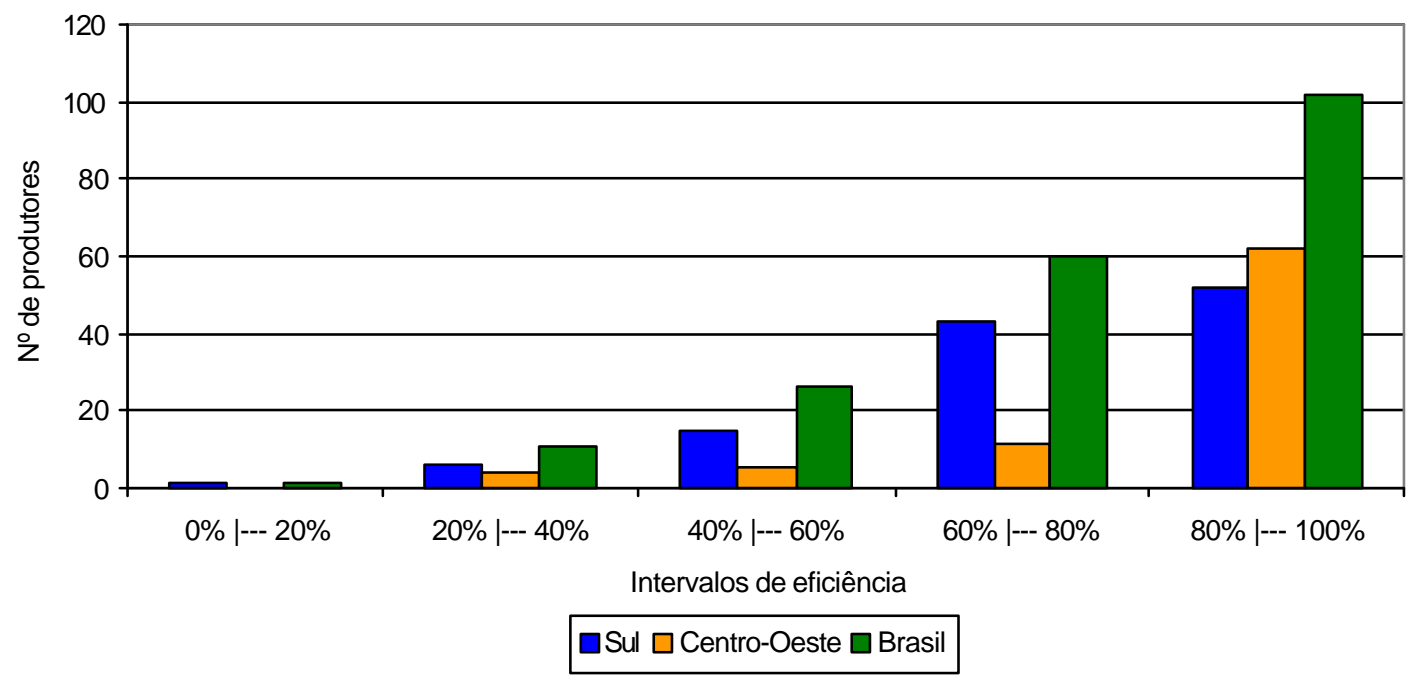

Figura 16 - Distribuição de frequiência das medidas de eficiência dos produtores das regiões Sul e Centro-Oeste.

Fonte: Dados de pesquisa.

O indicador de eficiência econômica para todo o Brasil, descrito na Figura 16, demonstra uma distribuição do número de produtores tal que a maior concentração das unidades produtivas encontra-se no intervalo de $80 \%$--- $100 \%$, englobando $51 \%$ da amostra. A faixa entre $60 \nmid--80 \%$ possui $30 \%$ dos produtores pesquisados e $19 \%$ das demais propriedades estão presentes nos outros intervalos.

$\mathrm{Na}$ Figura 17 dividiu-se a amostra em cinco partes iguais (quintis) para observar os efeitos da escala de produção sobre os índices de eficiência econômica dos produtores de frango de corte da região Sul do Brasil.

Percebe-se que, para essas unidades produtivas, não existem muitas diferenças nos índices de eficiência. Os produtores com escala de produção de até 10.000 
frangos/lote possuem em média uma eficiência econômica de $74,1 \%$ e os com produção superior a 26.000 frangos/lote, $75,1 \%$ de eficiência.

Dessa forma, observa-se que as diferentes escalas de produção encontradas na região Sul não resultaram em diferenças significativas nos níveis de eficiência, ou seja, maiores escalas de produção não resultam em melhores níveis.

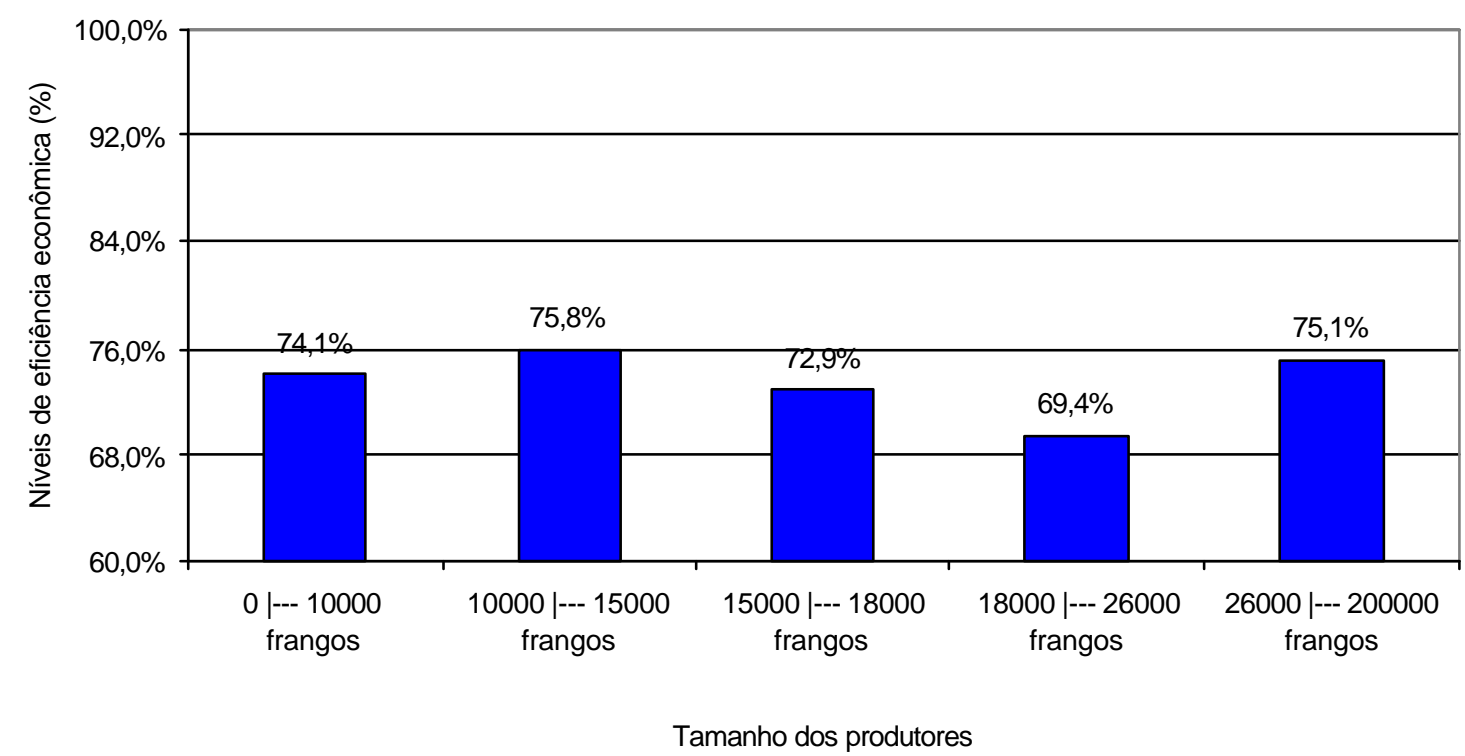

Figura 17 - Níveis de eficiência econômica dos produtores da região Sul por tamanho da produção (\%).

Fonte: Dados de pesquisa.

Já para os produtores de frango de corte da região Centro-Oeste, visualizados na Figura 18, nota-se que tendem a ser mais eficientes quanto maior for a escala de produção.

As unidades produtivas com produção inferior a 18.000 frangos/lote possuem uma eficiência média de $68,1 \%$. E os produtores com escala superior a 90.000 frangos/lote alcançaram uma média de $85,8 \%$ de eficiência econômica.

Assim, há indícios de que os produtores com maiores escalas de produção conseguem ser mais competitivos do que aqueles com pequenas escalas. Vários fatores 
podem estar relacionados a esses resultados, como, por exemplo, o maior investimento em tecnologia, maior profissionalização dos produtores, etc.

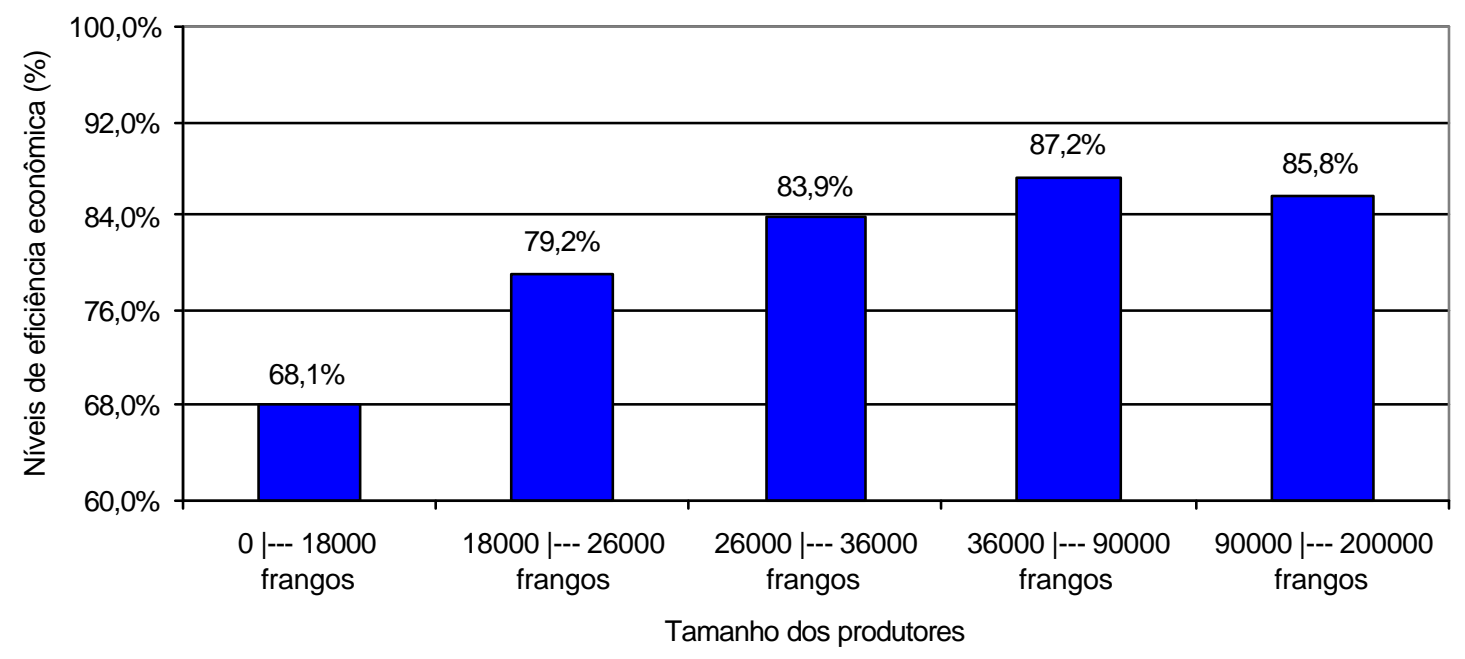

Figura 18 - Níveis de eficiência econômica dos produtores da região Centro-Oeste por tamanho da produção (\%).

Fonte: Dados de pesquisa.

Na Figura 19, pode-se ver os níveis de eficiência econômica dos produtores do Brasil. As informações agregadas para o País resultaram em maior eficiência para os produtores com maiores escalas de produção. As unidades produtivas pertencentes à faixa superior a 38.000 frangos/lote obtiveram uma medida de eficiência média de $81,7 \%$ diante de $72,2 \%$ dos produtores com produção inferior a 13.600 frangos/lote. Nos demais intervalos, percebe-se um crescimento nos níveis de eficiência conforme se aumenta as escalas de produção. Isso pode sugerir a presença de economias de escala na produção de frango de corte, principalmente na questão de competitividade entre os pequenos e os grandes produtores.

A escala de produção tem sido um dos fatores que influenciam o deslocamento da atividade avícola para a região Centro-Oeste, e essa análise demonstra que, em nível de eficiência econômica, as propriedades conseguem exercer os preceitos dos ganhos de escala. 
Diante disso, percebe-se que os produtores considerados pequenos em escala de produção estão, em ambas as regiões, obtendo índices de eficiência inferiores aos demais produtores, preservadas as diferentes escalas.

Vários fatores podem estar influenciando essa inferioridade dos pequenos produtores. A análise dos efeitos de ineficiência realizada pela estimação da fronteira de lucro estocástica forneceu indícios de que alguns fatores podem estar interferindo na produção avícola brasileira (ver Tabela 16). Porém, muitos esforços devem ser feitos para identificar realmente quais fatores possuem maior impacto sobre a eficiência desses produtores.

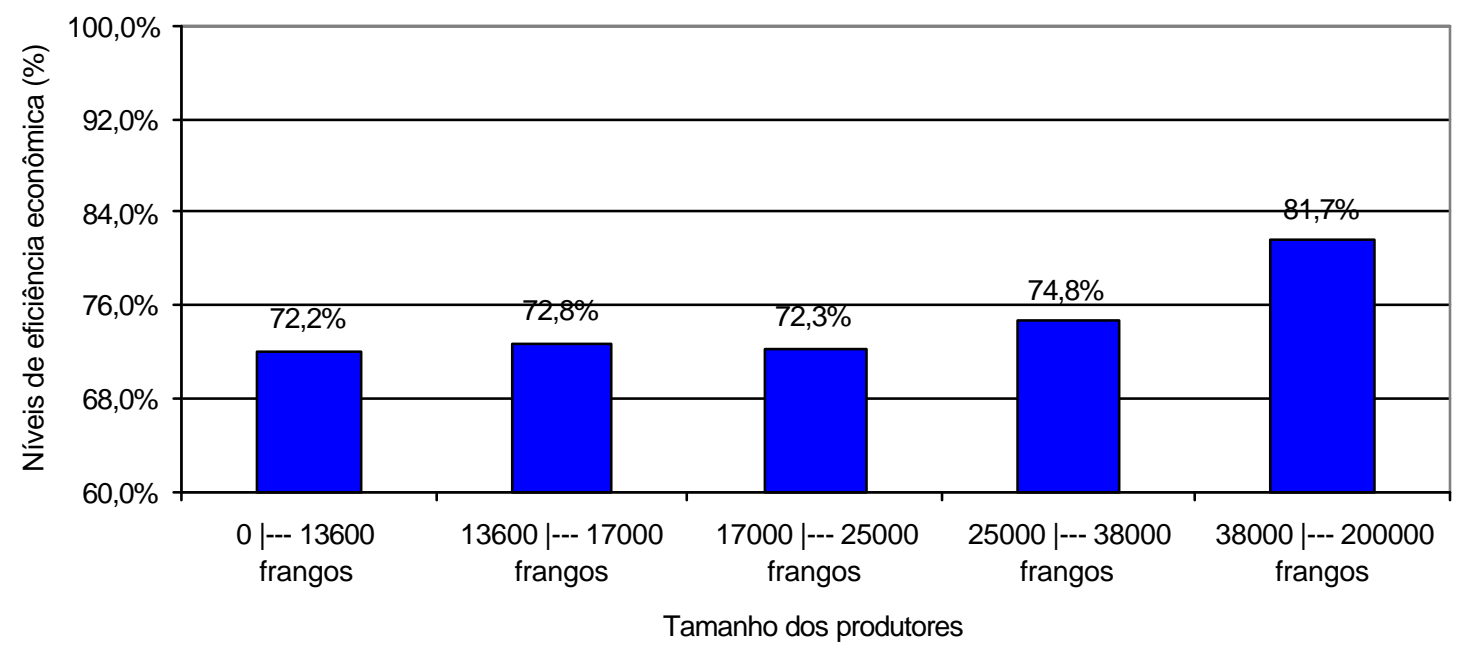

Figura 19 - Níveis de eficiência econômica dos produtores amostrados no Brasil por tamanho da produção (\%).

Fonte: Dados de pesquisa.

Talvez, a disseminação do novo modelo de integração baseada em médios/grandes produtores resulte da busca por maiores níveis de eficiência, visando à conquista de novos mercados por meio do aumento da competitividade da cadeia avícola brasileira.

Nesse sentido, os pequenos produtores ou os produtores menos eficientes correm 
o risco de ser excluídos do sistema produtivo, visto que existe a necessidade de concorrer em um mercado altamente competitivo. Para as agroindústrias, a manutenção dos produtores ineficientes torna-se custoso do ponto de vista dos retornos financeiros que sua produção adquire. 


\section{CONCLUSÕES}

Neste presente trabalho, pesquisaram-se os principais determinantes da ineficiência dos produtores de frango de corte, adotando-se uma função fronteira de lucro estocástica como método de análise.

Primeiramente, o modelo estimado preserva as leis fundamentais da economia da produção. As propriedades de uma função fronteira de lucro (homogeneidade, simetria e convexidade) são impostas na metodologia.

Estimaram-se as ineficiências dos produtores da região Sul (RS, SC e PR) e do Centro-Oeste (MS, MT e GO), usando-se a forma funcional Cobb-Douglas.

Conclui-se que o uso de mão-de-obra contratada na região Sul fornece indícios de influência negativa na lucratividade. Talvez essa seja uma das causas que proporcionem maior intensificação do uso da mão-de-obra familiar na região, visto que há questões culturais atreladas às etnias européias. O cuidado empregado por essas pessoas tem sugerido a existência de rendimentos marginais decrescentes, ou seja, o total de horas gastas com a atividade pode prejudicar a lucratividade. Com isso, a possível redução do tempo gasto poderia melhorar o seu lucro.

Entretanto, a região Centro-Oeste passa pelo processo inverso. A significância dos resultados fornece indícios de que o maior emprego de mão-de-obra familiar poderia elevar os índices de lucratividade.

Os dados consolidados para o Brasil identificaram que o preço da eletricidade possui significância no aumento do lucro dos produtores. O uso da energia elétrica é um dos fatores que determinam o crescimento dos frangos de corte, visto que a questão do fotoperíodo influencia os índices de conversão alimentar. Isso tem sido muito utilizado pelos produtores como controle do crescimento e do consumo de ração. 
A exemplo da eletricidade, o preço da forração pode estar influenciando a lucratividade do setor na análise para o Brasil. A existência de diferentes tipos de forração utilizados, a sazonalidade dos produtos e a baixa oferta em determinadas regiões tornam-se custosos para a atividade.

A região Sul consegue usar, de maneira mais eficiente, as áreas dos seus galpões, dados os tamanhos de suas propriedades. Entretanto, os resultados indicam que o produtor poderia aumentar mais suas estruturas para obter maiores níveis de lucratividade. Essa é uma conclusão importante, pois a necessidade de obtenção de renda nessas propriedades passa pela correta utilização das suas áreas de terra, que, além de ser pequenas, são bastante acidentadas, dificultando o uso do solo para a agricultura. Para o Brasil captou-se o mesmo resultado.

Como se esperava, os investimentos realizados no Centro-Oeste possuem características benéficas aos produtores, aumentando sua lucratividade. $\mathrm{O}$ fato de ser uma região relativamente nova e possuir condições favoráveis ao investimento incentiva a utilização intensiva de capital e tecnologia. Além disso, conta com a proximidade dos principais insumos que acarretam em redução nos custos de produção da agroindústria.

Os principais determinantes da ineficiência indicam conclusões que sugerem a precaução futura dos agentes ligados à atividade. A produtividade (conversão alimentar) da região Sul atingiu índices significantes perante os do Centro-Oeste, o que os deixa em posição mais confortável diante da eficiência econômica. O dinamismo e $\mathrm{o}$ profissionalismo que a atividade tem empregado foram fatores relevantes para a obtenção desses elevados ganhos de produtividade. Entretanto, a região Centro-Oeste precisa controlar melhor a conversão, pois os resultados mostram que maiores índices resultam em menores eficiências para os produtores. O pouco tempo na atividade pode estar influenciando os resultados.

Para os gastos com mitigação ambiental, conclui-se que existem indícios de nãointerferência na eficiência dos produtores nas regiões pesquisadas. Atualmente essa variável não se está traduzindo em problemas para a sociedade, visto que o resíduo ainda possui um valor de mercado. Porém, muita atenção deve ser dada para evitar qualquer tipo de sanção sobre as transações comerciais brasileiras de carne de frango. Os elevados 
índices de concentração, associados aos grandes volumes de resíduos produzidos, já fornecem alguns indícios de problema na região Sul. Dessa forma, as agroindústrias, em parceria com os órgãos públicos, devem criar soluções cabíveis para amenizar os problemas causados pelas questões ambientais.

O modelo não identificou ganhos de escala em nenhuma região amostrada. Entretanto, a análise gráfica sugere que a região Centro-Oeste tem economias de escalas nas suas propriedades. Essas influenciam a redução da ineficiência de seus produtores rurais. A conclusão simplesmente reforça o que tem sido um dos fatores que influenciaram a tendência de deslocamento da atividade para essa região. Para conseguirem competir com a produção brasileira, a necessidade de ganhos de escala se tornou requisito fundamental para o desenvolvimento da avicultura. Assim, os problemas enfrentados com a falta de experiência na atividade, a mão-de-obra pouco qualificada, etc., puderam ser superados com a estruturação de grandes escalas de produção. Portanto, eles competem em escalas e não em produtividade.

Com relação aos níveis de educação, nenhuma conclusão pôde ser feita. Os resultados para o Centro-Oeste indicam que os produtores com maior nível de educação apresentam menores índices de eficiência, quando se esperaria resultado contrário. Já para a região Sul, obteve-se resultado condizente com as expectativas. A explicação mais óbvia poderia ser a questão do sistema de produção no qual os produtores estão inseridos (integração vertical). Essa forma de produção restringe a aplicação dos conhecimentos obtidos, pois o pacote tecnológico e a assistência são fornecidos integralmente pela agroindústria.

Não se conseguiram evidências regionais de que os tomadores de decisões mais jovens são os mais eficientes. Entretanto, agregando as informações, obtiveram-se indícios de que os produtores mais velhos são mais ineficientes do que os mais jovens. $\mathrm{O}$ dinamismo destes associado a um maior nível de educação, pode estar influenciando esse resultado.

Os resultados não identificaram muitos fatores relacionados à ineficiência dos produtores de frango de corte nas regiões pesquisadas. Dessa forma, devem existir fatores extras que não foram abordados que podem estar afetando a eficiência 
econômica. Entretanto, várias hipóteses são levantadas para estudos futuros, visando controlar os efeitos da ineficiência sobre os produtores de frango de corte no Brasil.

Será que o sistema de produção estaria mascarando fatores de significativa relevância para a atividade? Nesse sentido, existe a necessidade de identificar o grau de influência da agroindústria nos resultados obtidos pelo avicultor.

$\mathrm{O}$ uso de tecnologia e de maiores escalas de produção estaria sufocando os produtores mais tradicionais e com pequenas escalas de produção, impondo a modernização da atividade? Será que essa hipótese pode, de fato, levar à exclusão dos pequenos produtores dado que os resultados mostram que eles possuem menores níveis de eficiência do que os produtores com grandes escalas? 


\section{REFERÊNCIAS BIBLIOGRÁFICAS}

ABDULAI, A.; HUFFMANN, W.E. An examination of profit inefficiency of rice farmers in northern Ghana. Ames: Iowa State University, 1998. 27p. (Staff Paper, 296)

AIGNER, D.; LOVELL, C.A.K.; SCHMIDT, P. Formulation and estimation of stochastic frontier production function models. Journal of Econometrics, v.6, n.1, p.21-37, 1977.

AIGNER, D.J.; CHU, S.F. On estimating the industry production function. Americam Economic Review, v.58, n.3, p.826-839, 1968.

ALI, F.P.; SHAH, M.K.A. Measurement of economic efficiency using the behavioral and stochastic cost frontier approach. Journal of Policy Modeling, v.18, n.3, p.271287, 1996.

ALI, M.; FLINN, J.C. Profit efficiency among basmati rice producers in Pakistan Punjab. American Journal of Agricultural Economics, v.71, n.2, p.303-310, May 1989.

ALMEIDA, L.S.; ARAÚJO, M.P. Estrutura, conduta e desempenho da cadeia avícola brasileira (compact disc). In: CONGRESSO BRASILEIRO DE ECONOMIA E SOCIOLOGIA RURAL, 38., Rio de Janeiro, 2000. Anais. Brasília: SOBER, 2000. $18 \mathrm{p}$.

ALVES FILHO, E. O processo de produção avícola: história e transformações. (contribuições ao estudo da avicultura em Minas Gerais 1980 - 1995). São Paulo, 1996. 215p. Tese (Doutorado) - Faculdade de Filosofia, Letras e Ciências Humanas, Universidade de São Paulo.

AP DEWI, I.; AXFORD, R.F.E.; FAYEZ, I.; MARAI, M.; OMED, H.M. Pollution in livestock production systems . Wallingford: CAB International, 1994. 464p.

ARAÚJO, M.P.; ALVES FILHO, E. Análise de sazonalidade do preço do esterco de frango na zona da Mata Mineira. Economia Rural, v.9, n.4, p.25-28, out./dez. 1998. 
ASSOCIAÇÃO BRASILEIRA DOS PRODUTORES E EXPORTADORES DE FRANGO (ABEF). Produção brasileira de frangos. http://www.abef.com.br (01 abr. 2003)

DO TERREIRO ao laboratório: os progressos da nutrição de aves. Aves \& Ovos. São Paulo, v.11, n.5, p.20-30, mar. 1995.

BATTESE, G.E.; COELLI, T.J. A model for technical inefficiency effects in a stochastic frontier prodution function for panel data. Empirical Economics, v.20, n.2, p.325-332, 1995.

BATTESE, G.E.; CORRA, G.S. Estimation of a production frontier model: with application to the pastoral zone of Eastern Australia. Australian Journal of Agricultural Economics, v.21, n.2, p.169-179, 1977.

CAMARA, M.R.G.; CARVALHO, S.C.; NAKAZATO, R.; SEREIA, V.; GOMES, S.J. Conduta e desempenho do sistema agroindustrial de frangos no norte do Paraná (compact disc). In: CONGRESSO BRASILEIRO DE ECONOMIA E SOCIOLOGIA RURAL, 38., Rio de Janeiro, 2000. Anais. Brasília: SOBER, 2000. 21p.

CAMARGO, A.M. de. Milagre do consumo. Anuário da avicultura industrial, v.1, n.1062, p.30-32, dez. 1998/jan. 1999.

CARMO, R.B.A. A viabilidade econômica da avicultura de corte na Bahia (compact disc). In: CONGRESSO BRASILEIRO DE ECONOMIA E SOCIOLOGIA RURAL, 39., Recife, 2001. Anais. Brasília: SOBER, 2001. 10p.

CARVALHO JUNIOR, L.C.; GELINSKI NETO, F. Análise da estrutura da indústria avícola brasileira (compact disc). In: CONGRESSO BRASILEIRO DE ECONOMIA E SOCIOLOGIA RURAL, 36., Poços de Caldas, 1998. Anais. Brasília: SOBER, 1998. 7 p.

CAZELLA, A.; TURNES, V.A. A política de financiamento rural e a agricultura familiar. In: CONGRESSO BRASILEIRO DE ECONOMIA E SOCIOLOGIA RURAL, 31., 1993. Anais. Brasília: SOBER, 1993. v.1, p.440-454.

CHARNES, A.; COOPER, W.W.; RHODES, E. Measuring the efficiency of decision making units. European Journal of Operational Research, v.2, n.6, p.429-444, 1978.

COELLI, T. J. Specification and estimation of stochastic frontier production functions. Armidale, 1996. 240p. Thesis (Pd.D.) - University of New England.

COELLI, T.J. A guide to DEAP version 2.1: a data envelopment analysis (computer) program. Armidale: CEPA, 1996. 50p. (Working papers, 8/96) 
COELLI, T.J. A guide to frontier version 4.1: a computer program for stochastic frontier production and cost function estimation. Armidale: CEPA, 1996. 33p. (Working Paper, 7/96)

COSTA, L.C.R.; ARAÚJO, M. da P. Integração vertical nas agroindústrias avícolas do oeste do oeste do Paraná: uma interpretação a partir dos custos de transação (compact disc). In: CONGRESSO BRASILEIRO DE ECONOMIA E SOCIOLOGIA RURAL, 39., Recife, 2001. Anais. Brasília: SOBER, 2001. 10p.

DINIZ, A. Análise das perspectivas de crescimento da avicultura de corte em Minas Gerais. http://www.agricultura.gov.br/spa/rpa1tri98/analise.doc (18 mar. 2003)

DURAISAMY, P. Technical and allocative efficiency of education in agricultural production: a profit function approach. Indian Economic Review, v.25, n.1, p.17-32, 1988.

FARE, R.; LOVELL, C.A.K. Measuring the technical efficiency of production. Journal of Economic Theory, v.19, n.1, p.150-162, Oct. 1978.

FARE, R.; GROSSKOPF, S.; LOVEL, C.A.K. Production frontier. Cambridge: University Press, 1994. 296p.

FARRELL, M.J. The measurement of productive efficiency. Journal of the Royal Statistical Society, v.120, n.3, Series A, p.253-290, 1957.

FERNANDES FILHO, J.F.; QUEIROZ, A.M. Transformações recentes na avicultura de corte brasileira: o caso do modelo de integração. Ouro Preto: UFOP, 2001. http://www.ufop.br/ichs/conifes/anais/OGT/ogt0106.htm. (04 out. 2003)

FERRAZ, J.C.; KUPFER, D.; HAGUENAUER, L. Made in Brazil: desafios competitivos para a indústria. Rio de Janeiro: Campus, 1995. p.1-53.

FERREIRA, A.A.; GOMES, MARILIA, F.M.; LIMA, J.E. Economia de escala e custo de produção de frango nas principais regiões produtoras de Minas Gerais. Revista Economia e Sociologia Rural, v.38, n.2, p.72-73, 2000.

FNP CONSULTORIA E AGROINFORMATIVOS. Agrianual 2003: anuário da pecuária brasileira. São Paulo, 2003. p.257-273: frango de corte.

FORSUND, F.R.; LOVELL, C.A.K.; SCHMIDT, P. A survey of frontier production functions and of their relationship to efficiency measuring. Journal of Econometrics, v.13, n.1, p.1-3, 1980. 
FUNDAÇÃO GETÚLIO VARGAS. Preços recebidos pelos produtores: frango de corte. http://fgvdados.fgv.br/ (04 abr. 2003)

GASQUES, J.G.; VILLA VERDE, C.M. Novas fontes de recursos, propostas e experiências de financiamento rural. Rio de Janeiro: IPEA, 1995b. (Texto para discussão, 392)

GRATERON, I.R.G. Contabilidade de animais difíceis de ser inventariados. In: MARION, J.C. (Coord.). Contabilidade e controladoria em agribusiness. São Paulo: Atlas, 1996. cap.2, p.30-42.

GOLDBERG, R.A. Agribusiness management for the development countries: latin america. Cambridge: Ballinger Publishing Co., 1974. 87p.

GUIMARÃES, V.D.A. Comercialização e transmissão de preços de carne de frango no estado de São Paulo. Piracicaba, 1990. 119p. Dissertação (Mestrado) - Escola Superior de Agricultura “Luiz de Queiroz”, Universidade de São Paulo.

GUJARATI, D.N. Econometria básica. 3.ed. São Paulo: Makron Books, 2000. 846p.

HENRY, R.; ROTHWELL, G. The world poultry industry. Washington, DC: World Bank, 1995. 74p.

INSTITUTO BRASILEIRO DE GEOGRAFIA E ESTATÍSTICA (IBGE). Pesquisa pecuária municipal: 2001. http://www.sidra.ibge.gov.br (01 abr. 2003)

INSTITUTO BRASILEIRO DE GEOGRAFIA E ESTATÍSTICA (IBGE). Censo agropecuário 1995/1996. http://www.sidra.ibge.gov.br (10 out. 2002)

JAYNE, T.S.; KHATRI, Y.; THIRTLE, C.; REARDON, T. Determinants of productivity change using a profit function: smallholder agriculture in Zimbabwe. Americam Journal of Agricultural Economics, v.76, n.3, p.613-618, 1994.

JANK, M.S. Organizações e estratégias nas exportações brasileiras de carnes. In: VIEIRA, W.; CARVALHO, F. Mercosul: agronegócios e desenvolvimento econômico. Viçosa: UFV, 1997. p.109-153.

JONDROW, J.; LOVELL, C.A.K.; MATEROV, I.S.; SCHMIDT, P. On the estimation of technical inefficiency in the stochastic frontier production function model. Journal of Econometrics, v.19, n.2, p.233-238, 1982.

KEBEDE , T.A. Farm household technical efficiency: a stochastic frontier analysis. http://www.ub.uib.no/elpub/norad/2001/nlh/thesis01.pdf. 2001 (01 June 2003) 
KODDE, D.; PALM, F. Wald criteria for jointly testing equality and inequality restritions. Econometrica, v.54, n.5, p.1243-1248, 1986.

KOOPMANS, T.C. An analysis of production as efficient combination of activities. In: KOOPMANS, T.C. (Ed.). Activity analysis of production and allocation. New York: John Wiley, 1951. p.33-97.

KUMBHAKAR, S.C. Efficiency estimation in a profit maximising model using flexible production function. Agricultural Economics, v.10, n.2, p.143-152, 1994.

LAU, L.J.; YOTOPOULUS, P.A. A test for relative efficiency and a application to Indian agriculture. Americam Economic Review, v.61, n.1, p.94-109, 1971.

LAZZARINI, S.G.; MACHADO FILHO, C.A.P.; NEVES, M.F.; STACCHINI, P.F. A indústria de nutrição animal: tendências e estratégias empresariais. In: CONGRESSO BRASILEIRO DE ECONOMIA E SOCIOLOGIA RURAL, 34., Aracajú, 1996. Anais. Brasília: SOBER, 1996. p.586-599.

MARQUES, P.V.; AGUIAR; D.R. Comercialização de produtos agrícolas. São Paulo: Edusp, 1993. 295p.

MEEUSEN, W.; VAN DER BROECK, J. Efficiency estimation from Cobb-Douglas production functions with composed error. International Economic Review, v.18, n.2, p.435-444, 1977.

NUNES, C.H. Consequiências da globalização na agricultura familiar: o caso avícola (compact disc). In: CONGRESSO BRASILEIRO DE ECONOMIA E SOCIOLOGIA RURAL, 38., Rio de Janeiro, 2000. Anais. Brasília: SOBER, 2000. 16p.

PERDOMO, C.C.; LIMA, G.J.M.M. de; NONES, K. Produção de suínos e meio ambiente. In: SEMINÁRIO NACIONAL DE DESENVOLVIMENTO DA SUINOCULTURA, 9., Gramado, 2001. Anais. Concórdia: Embrapa Suínos e Aves, 2001. p.8-24.

RANDALL, A. Resource economics: an economic approach to natural resource and environmental policy. New York: Eilley, 1987. 434p.

RICHETTI, A.; SANTOS, A.C. O sistema integrado de produção de frango de corte em Minas Gerais: uma análise sob a ótica da ECT. http://www.dae.ufla.br/cedoc/artigo03200.doc (18 mar. 2003)

SAHELI, S.; MACEDO, P.B.R. Eficiência técnica das unidades federativas brasileiras. Economia Aplicada, v.2, n.4, p.648-679, 1998. 
SANTANA, G.F. Distribuição regional da produção de frango. Preços Agrícolas, v.14, n.151, p.42, maio 1999.

SCHMITT, M.; REHM, G. Fertilizing cropland with poultry manure. Minnesota, 1998. http://www.extension.umn.edu/distribution/cropsystems/dc5881.html (18 Aug. 2002)

SCHRÖDER, M. O cooperativismo de crédito rural no oeste catarinense: possibilidades e limites de uma alternativa para a agricultura familiar (compact disc). In: CONGRESSO BRASILEIRO DE ECONOMIA E SOCIOLOGIA RURAL, 37., Foz do Iguaçu, 1999. Anais. Brasília: SOBER, 1999. 10p.

SCHULTZ, T.W. Transforming traditional agriculture. Newhaven: Yale University Press, 1964. 212p.

SHARMA, K.R.; LEUNG, P.; ZALESCKI, H.M. Technical, allocative and economic efficiencies in swine production in Hawaii: a comparison of parametric and nonparametric approaches. Agricultural Economics, v.20, n.1, p.23-35, 1999.

SHORR, H. Decisão estratégica. Anuário da avicultura industrial, v.1, n.1062, p.8898, dez. 1998/jan. 1999.

SMITH, R. Poultry manure handling: a practical approach. http://www.agric.gov.ab.ca (18 Aug. 2002)

SOUZA, R. de; GUIMARÃES, J.M.P.; VIEIRA, G. A administração da fazenda. São Paulo: Globo, 1992. 211p. (Coleção do Agricultor, Economia)

STREETER, D.H.; SONKA, S.T.; HUDSON, M. Information technology, coordination and competitiveness in the food and agribusiness sector. American Journal of Agricultural Economics, v.73, n.5, p.1465-1471, Dec. 1991.

STEINFELD, H.; DE HANN, C.; BLACKBURN, H. Options to address livestock: environmental interactions. http://www.fao.org/docrep/W5256T/w5256t03.htm (21 Oct. 2002)

TALAMINI, T.J.D.; SANTOS FILHO, J.I. dos; CANEVER, M.D. Os complexos grãoscarne e sua dinâmica recente no Brasil. In: CONGRESSO BRASILEIRO DE ECONOMIA E SOCIOLOGIA RURAL, 37., Poços de Caldas, 1998. Anais. Brasília: SOBER, 1998. 7p.

TUPY, O. Fronteiras estocásticas, dualidade neoclássica e eficiência econômica na produção de frangos de corte. Piracicaba, 1996. 91p. Tese (Doutorado) - Escola Superior de Agricultura 'Luiz de Queiroz" - Universidade de São Paulo. 
XU, X.; JEFFREY, S.R. Efficiency and technical progress in traditional and moderm agriculture: evidence from rice production in China. Agricultural Economics, v.18, n.2, p.157-165, 1998.

WILKINSON, J. Competitividade da agroindústria brasileira. Agricultura em São Paulo, v.42, n.1, p.27-56, jan.1995.

WIT, J. de; VAN KEULEN, H.; VAN DER MEER, H.G.; NELL, A.J. Animal manure: asset or liability. http://www.fao.org/docrep/W5256T/W5256t05.htm(21 Oct. 2002) 
APÊNDICES 
APÊNDICE 1 - Levantamento para caracterização de sistemas de produção de frangos.

Responsável pelo preenchimento

Número do questionário

1) IDENTIFICAÇÃO

Data: 12002 .

Entrevistado:

Cargo:

Proprietário da atividade:

Nome da Empresa/Integradora:

Município:

Estado:

Telefone: ( )

2) Tipo de produtor:

( ) Integrado ( ) Independente ( ) Cooperativas ( ) Outros

3) Se integrado ou cooperado, há quanto tempo? anos

4) Existe contrato com a integradora ou cooperativa?

( $\operatorname{Sim}($ ) Não

5) Se sim, qual é a garantia oferecida pela integradora ou cooperativa:

( ) Preço de Venda dos animais

( ) Entrega de pintainhos

( ) Entrega de ração

( ) Transporte dos animais

( ) Assistência técnica

( ) Recebimento de animais

( ) Medicamentos

( ) Outros

6) Se integrado ou cooperado, qual a periodicidade do contrato:

( ) Por ( ) anual ( ) semestral ( ) Outros 


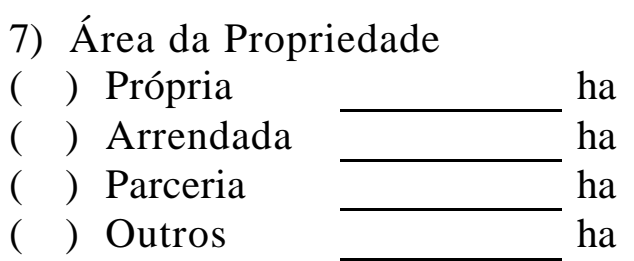

8) Área da propriedade ocupada com:

Lavoura

Pastagens $\mathrm{Ha}$

Ha

Mata nativa $\quad \mathrm{Ha}$

Recomposição de mata $\quad \mathrm{Ha}$

nativa

Área das construções

9) Procedência dos Pintos de 1 dia

( ) Incubatório Próprio

( ) Integradora

( ) Incubatório terceiros

( ) Outros

10) Forma de gerenciamento da propriedade

( ) Gerência do proprietário

( ) Gerência de outros membros da família

( ) Gerência contratada

( ) Outros

11) As decisões estratégicas são tomadas pelo

( ) Proprietário

( ) Gerente 
( ) Outros

12)Há algum tipo de assessoria gerencial? (Controle de custos, administração, etc)

( ) Sim. Qual ( ) Não

13) Tempo de existência da atividade frango na propriedade anos

14) Tempo que o tomador de decisão trabalha com atividade de frango anos.

15) Tempo que o tomador de decisão está na propriedade anos.

16) Experiência anterior do tomador de decisão com outras atividades agropecuárias?

( ) $\operatorname{Sim}($ ) Não

17) Se sim, quais?
( ) Suínos (

Onde (cidade/UF)?

18) O proprietário exerce outra atividade fora da propriedade?

( ) $\operatorname{Sim}($ ) Não

19) Da renda total do proprietário, qual o percentual líquido proveniente da produção de frangos? aposentadorias, pensões, aluguéis)

20) Da renda agrícola total, qual o percentual líquido proveniente da produção de frangos? $\%$ (incluindo $\%$

21)O tomador de decisão mora na propriedade?

( ) $\operatorname{Sim}(\quad)$ Não

22) Estado civil do tomador de decisão: 


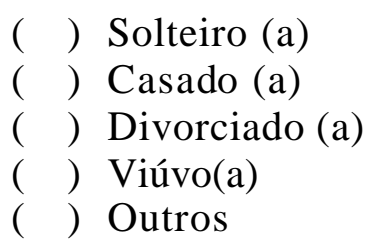

23) Idade do tomador de decisão: anos.

24) Idade da esposa do tomador de decisão: anos.

25)Escolaridade do gerente:

( ) Analfabeto

) $1^{\varrho}$ Incompleto

) $1^{\mathrm{o}}$ Completo

) $2^{\underline{\alpha}}$ Incompleto

) $2^{\underline{o}}$ Completo

) Superior incompleto

) Superior completo

( Ms.c, Ph. D

26) Escolaridade da esposa do tomador de decisão:

( ) Analfabeto

) $1^{\mathrm{O}}$ Incompleto

) $1^{\underline{o}}$ Completo

( ) $2^{\circ}$ Incompleto

( ) $2^{\mathrm{o}}$ Completo

( ) Superior incompleto

( ) Superior completo

( ) Ms.c, Ph. D 
27) Número de filhos do proprietário: filhos

28) Numero de filhas do proprietário: filhas

29) Escolaridade dos filhos do proprietário:

Quantidade Escolaridade Cursando

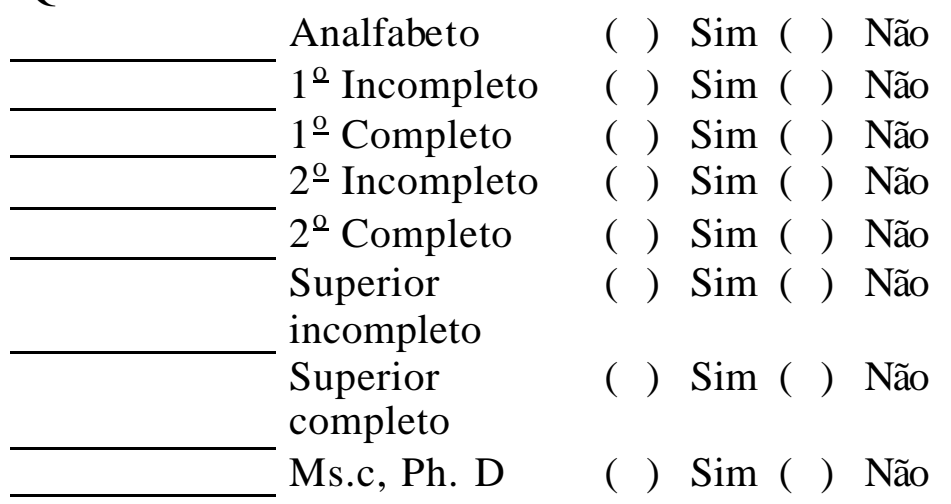

30) Número de pessoas que moram na propriedade: pessoas

31)O proprietário e/ou os membros de sua família trabalham na atividade avícola?

( ) $\operatorname{Sim}($ ) Não

32) Se sim, quais trabalham na atividade?

Membros da família

Dias de trabalho

Horas de trabalho/dia

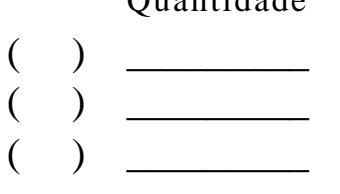

Proprietário

Esposa

$\longrightarrow \begin{aligned} & \text { Dias } \\ & \text { Dias } \\ & \text { Dias }\end{aligned}$

Horas

Filhos menores de 18 anos

Horas

Horas 


( ) $\begin{array}{ll}\text { Filhos maiores de } 18 \text { anos } & \text { Dias } \\ \text { Outros familiares } & \text { Dias }\end{array}$

33) Das pessoas que trabalham na atividade, algumas possui (em) formação técnica agropecuária?

( ) Sim ( ) Não

34) Se sim, qual é a formação técnica na atividade:

Formação técnica relacionada

$\mathrm{N}^{\circ}$ de pessoas $\quad$ Cargo/função

( ) Superior completo ligado a Ciências agrárias

( ) Superior incompleto ligado a Ciências agrárias

( ) Técnico agrícola completo

( ) Técnico agrícola incompleto

( ) Curso de especialização na área agropecuária nos últimos 2 anos

Tipo de treinamento

Quando? (último)

Unidade formadora

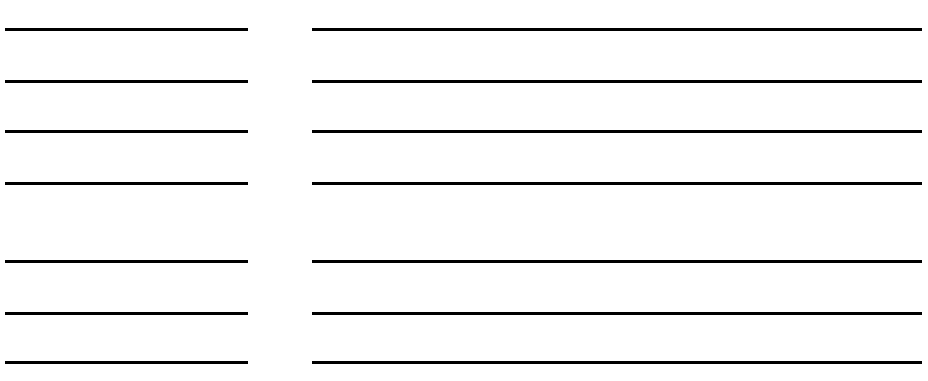

35) Mão-de-obra contratada na atividade (incluindo gerência - se contratada - e excluindo membros da família do proprietário):

Quantidade

Números de dias trabalhados

Horas /

Homem

/ lote

dias

Mulher

Horas

36) Programas de treinamento específicos para a atividade realizados nos últimos 2 anos com a mão-de-obra contratada: Tipo de treinamento Duração Instituiçãa promotora

\begin{tabular}{|l|l|}
\hline & \\
\hline & \\
\hline & \\
\hline
\end{tabular}


37) Existe mão-de-obra contratada para a administração da atividade?

( ) Sim ( ) Não

38) Se sim, qual o ${ }^{\circ}$ de pessoas e tempo de trabalho:

Quantidade

Números de dias

Dias

Dias
Horas /

dias

Horas

Horas

39) Escolaridade da mão-de- obra contratada que trabalham na atividade (excluindo administração e membros da família do proprietário):

$\begin{array}{ll}\text { Quantidade } & \text { Escolaridade } \\ & \text { Analfabeto } \\ & 1^{\mathrm{o}} \text { Incompleto } \\ & 1 \text { o Completo } \\ & 2^{\mathrm{o}} \text { Incompleto } \\ & 2^{\mathrm{Q}} \text { Completo } \\ & \text { Superior incompleto } \\ & \text { Superior completo } \\ & \text { Ms.c, Ph. D }\end{array}$

40) Escolaridade da mão-de-obra contratada que trabalham na administração da atividade:

Quantidade Escolaridade

Analfabeto

$1^{\circ}$ Incompleto

$1^{\circ}$ Completo

$2^{\circ}$ Incompleto

$2^{\underline{0}}$ Completo 
41) A unidade produtora está próxima a:

Tipos de fontes

Distância

Rios ou córregos

) Lagoas naturais

Represas

) Poços artesianos

) Mina d'água

) Poço natural (Cisterna)

) Outros

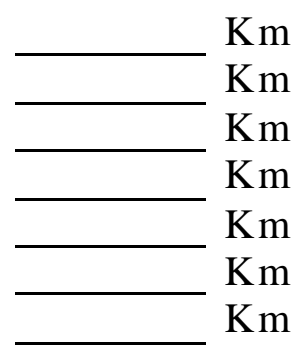

42) Distância da fonte de água para abastecimento da unidade produtora: Tipos de fontes

( ) Rios ou córregos

( ) Lagoas naturais

) Represas

) Poços artesianos Profundidade

) Mina d'água

Distância

) Rede de distribuição de água

) Outros

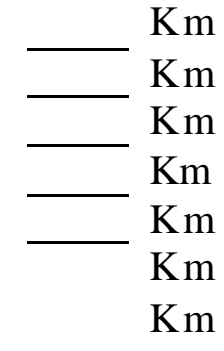

43) Distância da fonte de água para consumo doméstico:

Tipos de fontes

( ) Rios ou córregos

( ) Lagoas naturais

( ) Represas

( ) Poços

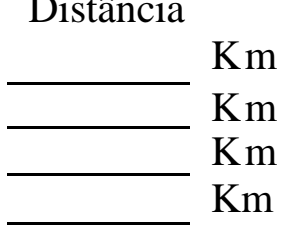


44) Distância da propriedade a sede do município:

$\mathrm{Km}$.

45)Distância da propriedade a maior cidade da microrregião:

46) Distância ao frigorífico:

$\mathrm{Km}$.

47) Distância média da unidade produtora das sedes das propriedades vizinhas $\mathrm{Km}$.

48) Distância média da(s) moradia(s) à unidade produtora: metros.

49) Distância da estrada: metros.

50) Quantas Casas (propriedades) existem num raio de:

\begin{tabular}{|l|c|c|c|}
\hline & Suínos & Avicultura & Leite \\
\hline 250 metros & & & \\
\hline 500 metros & & & \\
\hline
\end{tabular}

51) Produção Agrícola e uso de fertilizantes (última safra):

\begin{tabular}{|c|c|c|c|c|c|c|c|c|c|c|}
\hline \multirow[t]{3}{*}{ Cultura } & \multirow[t]{3}{*}{ - Produção/t } & \multirow[t]{3}{*}{ Área( há) } & \multicolumn{2}{|c|}{ Dejetos suínos } & Cama de frango & \multicolumn{5}{|c|}{ Uso fertilizante químico N-P-K } \\
\hline & & & & & Formulação: & \multicolumn{2}{|c|}{ Formulação: } & \multicolumn{2}{|c|}{ Formulação: } \\
\hline & & & & & & $-\quad-$ & - & - & - & \\
\hline Milho & & & $\mathrm{M}^{3}$ & ton & ton & ton & & ton & & ton \\
\hline Soja & & & $\mathrm{M}^{3}$ & ton & ton & ton & & ton & & ton \\
\hline Feijão & & & $\mathrm{M}^{3}$ & ton & ton & ton & & ton & & ton \\
\hline Arroz & & & $\mathrm{M}^{3}$ & ton & ton & ton & & ton & & ton \\
\hline Trigo & & & $\mathrm{M}^{3}$ & ton & ton & ton & & ton & & ton \\
\hline Cevada & & & $\mathrm{M}^{3}$ & ton & ton & ton & & ton & & ton \\
\hline & & & $\mathrm{M}^{3}$ & ton & ton & ton & & ton & & ton \\
\hline
\end{tabular}




\begin{tabular}{|c|c|c|c|c|c|c|c|c|c|}
\hline & & & & $\mathrm{M}^{3}$ & ton & ton & ton & ton & ton \\
\hline & & & & $\mathrm{M}^{3}$ & ton & ton & ton & ton & ton \\
\hline
\end{tabular}

52) Preço dos Insumos:

\begin{tabular}{ll}
\hline Fertilizantes & $\mathrm{R} \$ /$ Ton \\
\hline Uréia & \\
Super fosfato simples & \\
Cloreto de potássio & \\
NPK & \\
\hline
\end{tabular}

53) Quantidade de animais na propriedade:

Bovinos

Suínos

Eqüinos

Frangos de corte

Caprinos

Cabeças

Outros

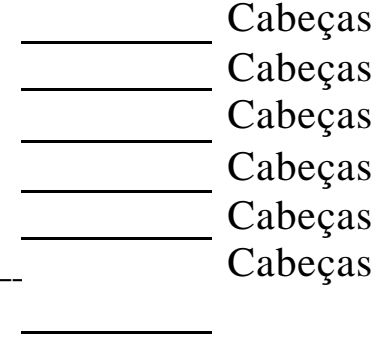

\section{REBANHO BOVINO}

54) Plantel de bovinos

Tipo de bovino

Touros

Vacas de leite

Novilhas

Quantidade

Cabeças

Bezerras (até 1 ano)

Cabeças

Bezerros

Cabeças

Cabeças

Gado de corte

Cabeças

Cabeças 


\section{REBANHO CAPRINO}

55) Plantel de caprinos

Tipo de caprinos

Fêmeas

Machos

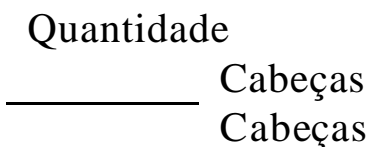

\section{REBANHO OVINO}

56) Plantel de ovinos

Tipo de ovinos

Fêmeas

Machos

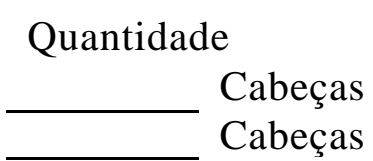

REBANHO SUÍNO

57) Plantel de suínos da propriedade

Cachaços

Matrizes

Animais

Marrã (Reposição)

Leitões

Animais

Terminados

Animais

Terminados Animais

REBANHO AVÍCOLA

58) Número de aviários para criação de frangos em escala comercial - capacidade de alojamento e tamanho.

$\mathrm{N}^{\mathrm{o}}$ de
Capacidade de Aloj. de cada

$m^{2}$
$m^{2}$
$m^{2}$
$m^{2}$
$m^{2}$
$m^{2}$

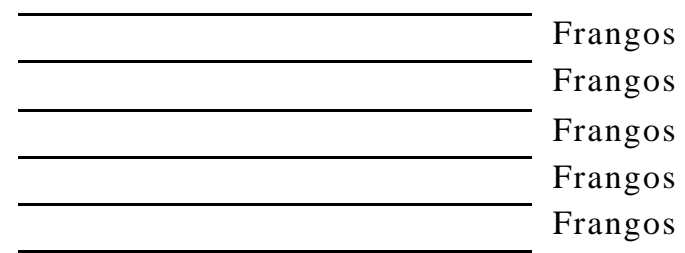

Ano de

Valor de

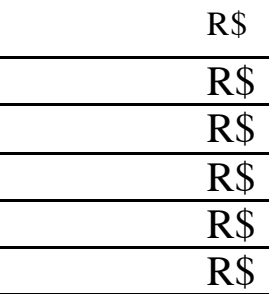




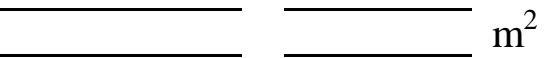

Frangos

59)Qual é a condição da(s) unidade(s) produtora(s)

( ) Ótima ( ) Boa ( ) Razoável ( ) Ruim

60) Como o acesso à unidade produtora

( ) Ótima ( ) Boa ( ) Razoável ( ) Ruim

61) Qual é a condição da água:

( ) Ótima ( ) Boa ( ) Razoável ( ) Ruim

62) Qual á a condição de sombra:

( ) Ótima ( ) Boa ( ) Razoável ( ) Ruim

63) Capacidade de alojamento (se separados por sexo):

$\begin{array}{lcc}\text { Sexo } & \text { Inverno } & \text { Verão } \\ \text { Machos } & \text { Frangos } & \text { Frangos } \\ \text { Fêmea } & \text { Frangos } & \text { Frangos } \\ \text { Misto } & \text { Frangos } & \text { Frangos }\end{array}$

64) Índices zootécnicos do último lote Descrição

Quantidade de pintainhos alojados

Quantidades de frangos entregues para abate

Autoconsumo de aves

Mortalidade:

Idade de abate do último lote

$\begin{array}{ll}\text { Valores } & \text { Unidades } \\ & \text { Cabeças } \\ & \text { Frangos } \\ & \text { Aves } \\ & \text { Aves } \\ & \text { Dias }\end{array}$


Conversão alimentar (Cons. total ração/peso

Peso médio

Ciclos/ano

Ganho de peso diário

Fator de produção

Ciclos/cama de aviário

Preço recebido/Ave

Condição de Pagamento

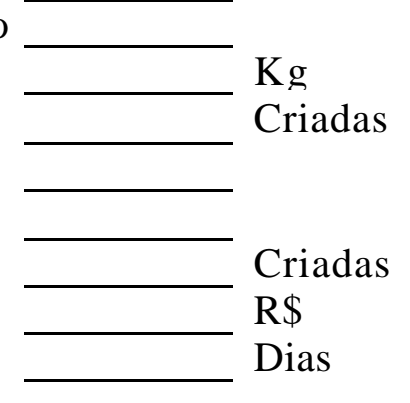

65)Custos de produção

Descriminação

Pintos de 1 dia

Rações

Ração Pré - Inicial

Ração Inicial

Ração Engorda

Ração Final

Gastos com apanha (carregamento) de frango

Água consumida $\mathrm{M}^{3}$

Energia Elétrica

Gás

Lenha

Forração de pisos pós - desinfecção/Cama (ton)

Manutenção da forração/lote (ton)

Mão-de-obra - salários

Mão-de-obra: encargos/mês na atividade

Mão-de-obra diarista

Mão-de-obra: benefícios não financeiros (Moradia,

Encargos sociais sobre produção

Funrural 2,3\%
Preço Unitário Nota

Quantidade

Cabeças
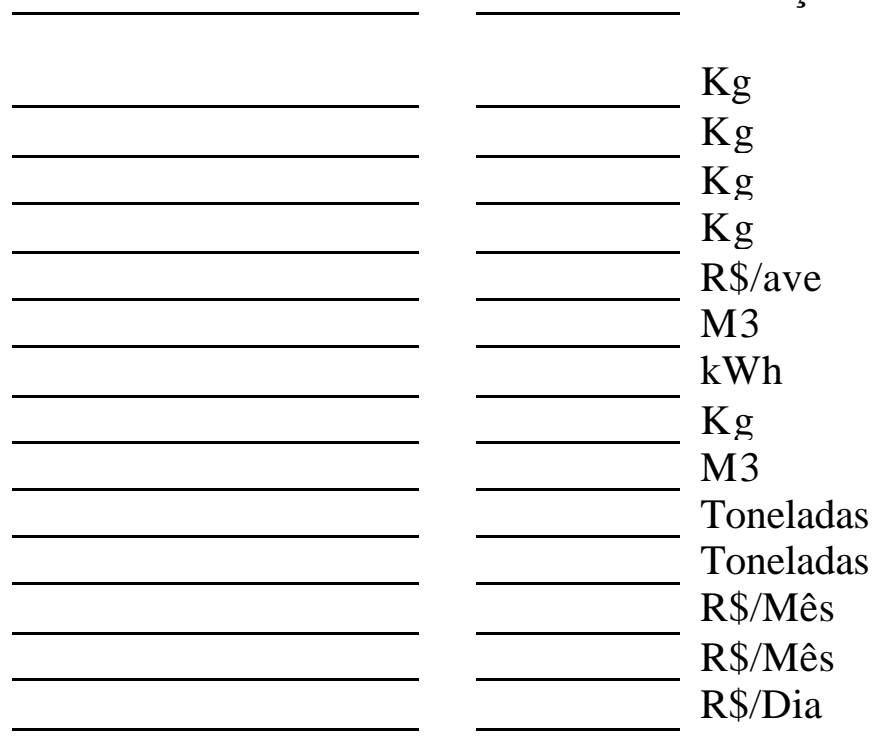

$\mathrm{R} \$$ 
Sindicatos

Associações

Cooperativas

Federações

Outros

Aperfeiçoamento técnico e profissional do

Transportes (Pintainhos) R $\$ / \mathrm{km}$

Transportes (Ração) $\mathrm{R} \$ / \mathrm{km} /$ peso

Transportes (Aves p/ abate) R $\$ / \mathrm{km} /$ peso

Manutenção e reparos dos equipamentos

Outros serviços

Outras despesas do lote

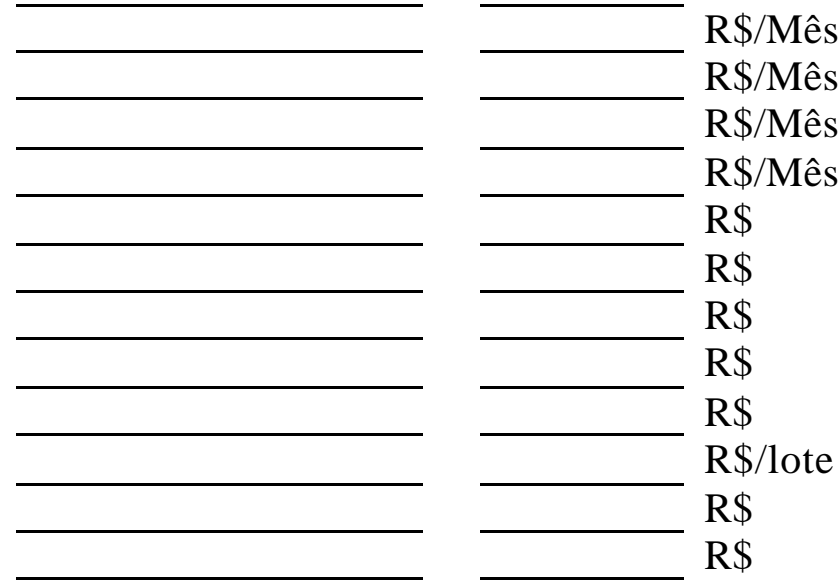

66) Medicamentos e vacinas do último lote

Descriminação

Medicamentos

Preço Unitário Quantidade

Vacinas

New Castlle

Gumboro

67) Material de desinfecção

Descriminação

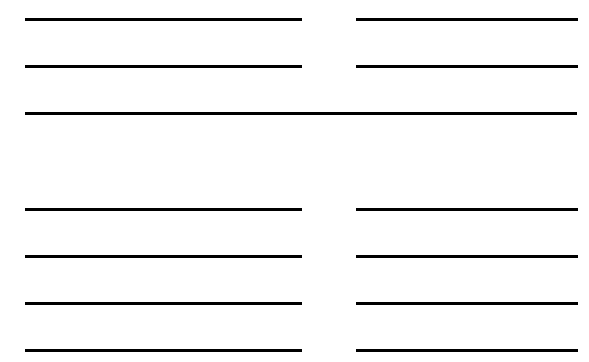

Preço Quantidade

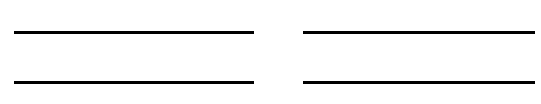




\section{8) Existe reposição dos frangos de corte refugados e/ou mortos}

( ) $\operatorname{Sim}($ ) Não

69) Quem é o responsável pela reposição dos frangos

( ) Integradora ( ) Produtor ( Cooperativas ( ) Outros

70) Cama de frango (último lote):

Produção

Venda

Preço médio

Consumo Ton.

Ton.
Reais/ton
Ton.

71) Forração utilizada na cama de frango:

( ) Palha de ( ) Palha de ( ) Serragem ( ) Palha de arroz Outros

72) Costuma armazenar a cama de frango antes de utilizá-la e/ou vendê-la?
( ) Sim
( ) Não

73) Em que condições armazena essa cama?

( ) Descoberta sob o ( ) Coberta sob o ( ) Ensacada ( ) Outros

74) Qual é o custo dessa armazenagem?

$\mathrm{R} \$$

75) Caso realize venda de cama (última cama vendida/lote):

Destino (cidade, UF) 


\section{( ) Vendedor Custo: R\$}

Responsabilidade pelo transporte

) Comprador

( ) Vendedor Custo: $\mathrm{R} \$$

76) Se faz uso da cama de frango na propriedade, qual o destino?

( ) Pecuária. Desde:

( ) Pastagem__ Desde:

Outros

77) Aproveitamento na propriedade (Última aplicação):

MO contratada utilizada na disposição

MO familiar utilizada na disposição Homens

Quantidade de dias do mês utilizados p/

Horas/dia utilizadas p/ disposição

Horas máquinas

Horas equipamentos

Custo da disposição feita por terceiros

Redução do uso de fertilizantes - NPK

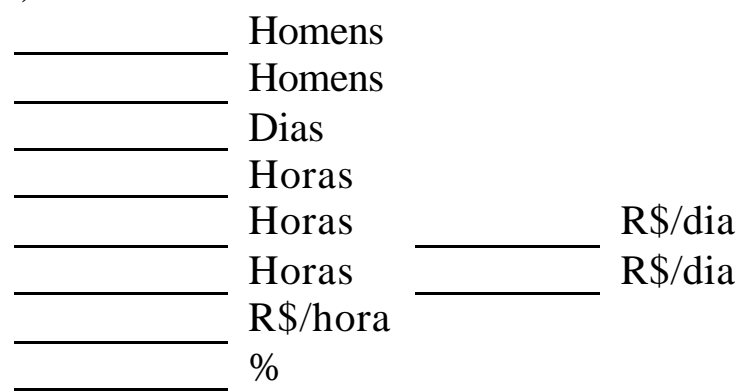

78) Existe comercialização de embalagens acumuladas provenientes do uso de produtos ou insumos

( ) $\operatorname{Sim}($ Não

79) Tipo de embalagens comercializadas

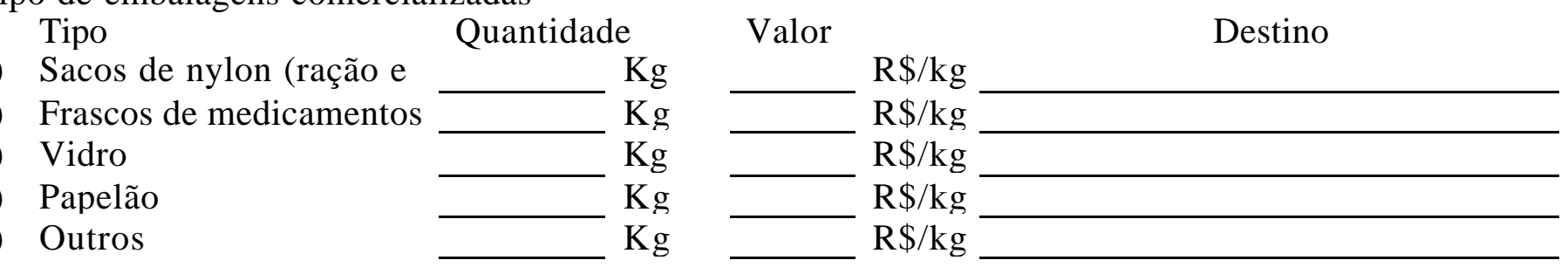


80) Responsabilidade pelo controle sanitário do plantel e custos

$$
\text { Serviço técnico }
$$

( ) Técnico/veterinário contratado pela agroindústria

( ) Técnico/veterinário contratado pelo produtor

( ) Técnico/veterinário contratado pela cooperativa

( ) Técnico/veterinário contratado pela associação

( ) Outros

81)Existe acompanhamento técnico para manejo de dejetos dentro do galpão?

( ) Sim

( ) Não

82) Existe acompanhamento técnico para manejo de dejetos fora do galpão?
( ) Sim
( ) Não

83) Se existe acompanhamento técnico, o técnico é:

( ) Contratado ( ) das Cooperativas

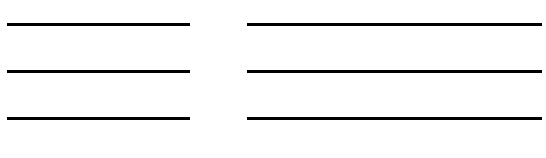

84) Qual o destino dos animais mortos:

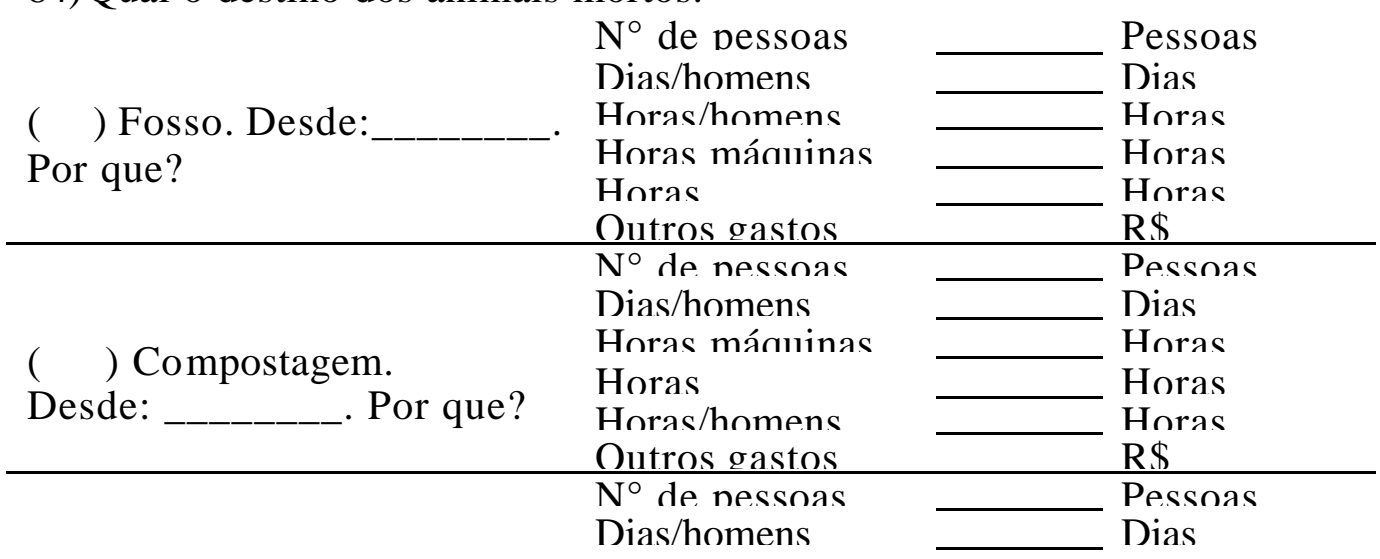




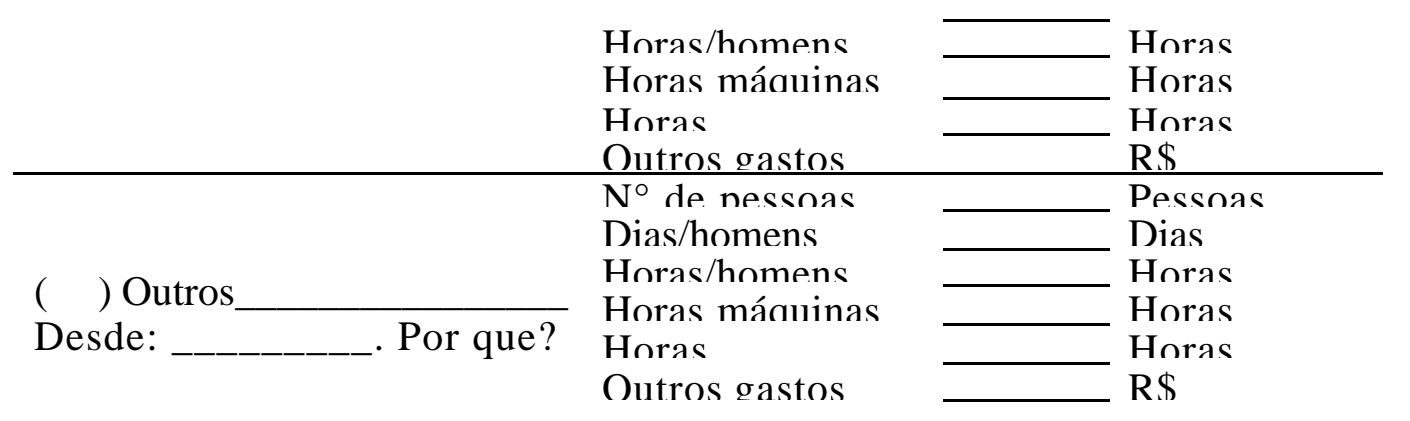

85) Existe alguma forma de remuneração para os seus vizinhos como compensação dos efeitos da atividade no ambiente (odores, poluição água, poluição solo, etc.)

( ) Sim. Valor $\mathrm{R} \$$ （） Não

86) Existe impostos, taxas ou licenças relativas a questões ambientais e sanitárias na atividade avícola?

( ) Sim. ( ) Não

87) Quais são essas taxas e seus custos:

Taxas e licenças ambientais e sanitárias

Custo em R \$/ano

$+2$

88) Existe uma legislação ambiental a ser seguida para o desempenho da atividade:

( ) $\operatorname{Sim}($ ) Não

89) Se sim, qual o nível da legislação:

( ) Municipal ( ) Estadual ( ) Federal 
90) Maquinaria, instalações.

a) Relação das Instalações

\begin{tabular}{|l|l|l|l|l|l|l|}
\hline Descrição & Quantidade & Tamanho & Capacidade & Valor de aquisição & Ano de construção/aquisição & Vida útil \\
\hline Casa do empregado & & & & & & \\
\hline Casa do proprietário & & & & & & \\
\hline Outros Galpões & & & & & & \\
\hline Trator & & & & & & \\
\hline Caminhão & & & & & & \\
\hline Carreta & & & & & & \\
\hline Distr. de esterco & & & & & & \\
\hline Lago de tratamento & & & & & & \\
\hline Biodigestor & & & & & & \\
\hline Silo metálico & & & & & & \\
\hline Silo madeira & & & & & & \\
\hline Outros veículos & & & & & & \\
\hline
\end{tabular}

b) Equipamentos - Frango de corte

\begin{tabular}{|c|c|c|c|c|}
\hline$(\quad)$ & $\begin{array}{l}\text { Equipamentos } \\
\text { Boca de silo }\end{array}$ & Ouantidade & Valor de aquisição & Potência (hp, w) \\
\hline$(\quad)$ & Campânulas a gás & & & \\
\hline ) & Tonéis a lenha & & & \\
\hline ( & Central de aquecimento & & & \\
\hline( & Comedouro tubular adulto & & & \\
\hline( & Comedouro tubular infantil & & & \\
\hline( & Comedouro automático & & & \\
\hline( & Bebedouro pendular infantil & & & \\
\hline( & Bebedouro infantil & & & \\
\hline( & Bebedouro pendular adulto & & & \\
\hline( & Beb. Niple completo 1500 & & & \\
\hline( & Coniunto total de Cortinas M2 & & & \\
\hline
\end{tabular}




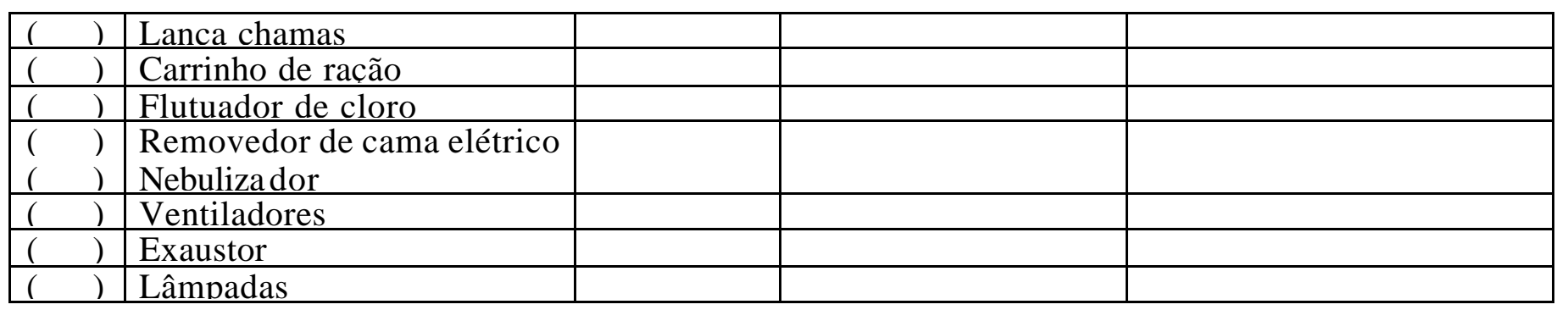

91) Todos os insumos utilizados são fornecidos pela integradora:

( ) $\operatorname{Sim}($ ) Não

92) Existe alguma exigência de garantia por parte da integradora para com o produtor?

( ) Não ( ) Sim. Qual?

93) Tem alguma bonificação por eficiência produtiva?

( ) Não ( ) Sim. Qual?

94) Comercialização dos animais vivos com a intregadora é $100 \%$ ?

( ) $\operatorname{Sim}($ ) Não

95) Qual o destino do produto?

( ) Mercado Interno ( ) Mercado Externo

96) Recorre ou recorreu a fontes de financiamento para investimentos na propriedade nos últimos 5 anos

( ) Sim ( ) Não

97) Finalidade do financiamento

( ) Custeio da produção 
) Construções

) Reformas das instalações

) Aquisição de equipamentos

) Aquisição de Máquinas e

) Tratamento de dejetos

) Outros

98) Onde consegue os recursos para Investimento

( ) Próprio

( ) Banco público

( ) Banco privado

( ) Cooperativa de

( ) Integradora

( ) BNDES

99) Qual a taxa de juros? $\%$ aa.

100) Qual o volume do ultimo empréstimo realizado $\mathrm{R} \$$ Qual o destino?

Taxa de juros:

\section{ASPECTOS SOCIAIS GERAIS}

101) É filiado a alguma Cooperativa?

( ) $\operatorname{Sim}($ ) Não Qual?

a) Como é a sua atuação na cooperativa?

( ) Excelente ( ) Muito ( Bom ( Regular ( Ruim (

b) O que o senhor acha da atuação da cooperativa?

( ) Excelente ( ) Muito ( Bom ( Regular ( Ruim ( 
102) É filiado a alguma Associação?

( ) Sim ( ) Não Qual?

a) Como é a sua atuação na Associação?

( ) Excelente ( ) Muito ( Bom ( Regular ( Ruim (

b) O que o senhor acha da atuação da Associação?

( ) Excelente ( ) Muito ( Bom ( Regular ( Ruim (

103) É filiado a algum Sindicato?

( ) Sim ( ) Não Qual?

a) Como é a sua atuação no Sindicato?

( ) Excelente ( ) Muito ( Bom ( Regular ( Ruim (

b) O que o senhor acha da atuação do Sindicato?

( ) Excelente ( ) Muito ( Bom ( Regular ( Ruim (

104) É filiado a alguma Federação?

( ) Sim ( ) Não Qual?

a) Como é a sua atuação na Federação?

( ) Excelente ( ) Muito ( ) Bom ( ) Regular ( ) Ruim ( )

b) O que o senhor acha da atuação da Federação?

( ) Excelente ( ) Muito ( ) Bom ( ) Regular ( ) Ruim ( )

105) Meios de comunicação que o tomador de decisão tem acesso:

( ) Televisão ( ) TV a cabo ( ) Telefone ( ) Rádio （） Jornais ( ) 
( ) Internet ( ) Parabólica ( ) Informativos ( ) Revista ( ) Telefone

106) Possui os seguintes benefícios:

( ) Estrada cascalhada

( ) Tratamento de

) Água encanada

( ) Tratamento de

( ) Eletricidade

Escola rural

( ) Transporte rural

( ) Outros

107) Quais são os principais problemas da propriedade?

( ) Prazo de pagamento

( ) Comercialização

( ) Inadimplência

( ) Assistência técnica

( ) Qualidade de insumos

( ) Política agrícola

( ) Crédito

( ) Barreiras fitossanitária de outros estados e

( ) Outros

108) Origem e formação da propriedade, ligação com a agricultura de parte dos membros da família, perspectivas? 
APÊNDICE 2 - Coeficientes estimados para a região Sul.

\section{REGIÃO SUL}

pi Lucro

Beta 1 Preço da eletricidade

Beta 2 Preço do trabalho contratado

Beta 3 Preço da forração

Beta 4 Preço Carregamento

Beta 5 Preço do aquecimento

Beta 6 Área ocupada

Beta 7 Trabalho familiar

Beta 8 Capital

Delta1 Conversão alimentar

Delta 2 Gastos com mitigação ambiental

Delta 3 Concentração animal na fazenda

Delta 4 Escala de produção

Delta 5 Experiência na atividade

Delta 6 Escolaridade

Delta 7 Idade do gerente

Delta 8 Possui atividade fora propriedade

Delta 9 Mora na propriedade
$\mathrm{R} \$ / \mathrm{Pr}$

$\mathrm{R} \$ / \mathrm{KwH} / \mathrm{Pr}$

$\mathrm{R} \$ /$ horas/Pr

$\mathrm{R} \$ / \mathrm{t} / \mathrm{Pr}$

$\mathrm{R} \$ /$ frango/Pr

$\mathrm{R} \$ / \mathrm{kcal} / \mathrm{Pr}$

$\mathrm{M}^{2}$

Horas

$\mathrm{R} \$$

$\mathrm{kg}$ ração/kg frango vivo

$\mathrm{R} \$$

Frango/ha

Frango

Anos

$\mathrm{E} 1<3=0 ; 1$

Anos

Dummy 0 = Não, $1=$ Sim

Dummy $0=$ Não, $1=$ Sim

Output from the program FRONTIER (Version 4,1c)

Tech, Eff, Effects Frontier (see B\&C 1993)

The model is a production function

The dependent variable is logged

the ols estimates are :

coefficient standard-error t-ratio

beta $0 \quad 0,49076430 \mathrm{E}+01 \quad 0,82927154 \mathrm{E}+00 \quad 0,59180169 \mathrm{E}+01$

beta $1-0,18127548 \mathrm{E}+00 \quad 0,28861390 \mathrm{E}+00-0,62808991 \mathrm{E}+00$

beta $2-0,69656365 \mathrm{E}-02 \quad 0,16704828 \mathrm{E}-01-0,41698342 \mathrm{E}+00$

beta $3-0,33129166 \mathrm{E}-01 \quad 0,13371493 \mathrm{E}+00-0,24775966 \mathrm{E}+00$

beta $4 \quad 0,14288212 \mathrm{E}+00 \quad 0,14389284 \mathrm{E}+00 \quad 0,99297588 \mathrm{E}+00$

beta $5 \quad-0,50836783 \mathrm{E}-01 \quad 0,37162983 \mathrm{E}-01-0,13679414 \mathrm{E}+01$

beta $6 \quad 0,50512277 \mathrm{E}+00 \quad 0,14658836 \mathrm{E}+00 \quad 0,34458587 \mathrm{E}+01$

beta $7 \quad-0,30609937 \mathrm{E}-01 \quad 0,21005567 \mathrm{E}-01-0,14572297 \mathrm{E}+01$

beta $8 \quad 0,30879001 \mathrm{E}+00 \quad 0,16851561 \mathrm{E}+00 \quad 0,18324119 \mathrm{E}+01$ 
sigma-squared $0,21373769 \mathrm{E}+00$

$\log$ likelihood function $=-0,71067471 \mathrm{E}+02$

the estimates after the grid search were :

$\begin{array}{lc}\text { beta } 0 & 0,54083283 \mathrm{E}+01 \\ \text { beta } 1 & -0,18127548 \mathrm{E}+00 \\ \text { beta } 2 & -0,69656365 \mathrm{E}-02 \\ \text { beta } 3 & -0,33129166 \mathrm{E}-01 \\ \text { beta } 4 & 0,14288212 \mathrm{E}+00 \\ \text { beta } 5 & -0,50836783 \mathrm{E}-01 \\ \text { beta } 6 & 0,50512277 \mathrm{E}+00 \\ \text { beta 7 } & -0,30609937 \mathrm{E}-01 \\ \text { beta } 8 & 0,30879001 \mathrm{E}+00 \\ \text { delta } 0 & 0,00000000 \mathrm{E}+00 \\ \text { delta } 1 & 0,00000000 \mathrm{E}+00 \\ \text { delta } 2 & 0,00000000 \mathrm{E}+00 \\ \text { delta } 3 & 0,00000000 \mathrm{E}+00 \\ \text { delta } 4 & 0,00000000 \mathrm{E}+00 \\ \text { delta } 5 & 0,00000000 \mathrm{E}+00 \\ \text { delta } 6 & 0,00000000 \mathrm{E}+00 \\ \text { delta 7 } & 0,00000000 \mathrm{E}+00 \\ \text { delta } 8 & 0,00000000 \mathrm{E}+00 \\ \text { delta } 9 & 0,00000000 \mathrm{E}+00 \\ \text { sigma-squared } 0,44798211 \mathrm{E}+00 \\ \text { gamma } & 0,87900000 \mathrm{E}+00\end{array}$

the final mle estimates are :

coefficient standard-error t-ratio

beta $0 \quad 0,51440943 \mathrm{E}+01 \quad 0,65539031 \mathrm{E}+00 \quad 0,78489020 \mathrm{E}+01$

beta $1-0,29637535 \mathrm{E}-02 \quad 0,19661287 \mathrm{E}+00-0,15074056 \mathrm{E}-01$

beta $2 \quad-0,21762603 \mathrm{E}-01 \quad 0,12318403 \mathrm{E}-01-0,17666740 \mathrm{E}+01$

beta $3 \quad-0,95768762 \mathrm{E}-01 \quad 0,95817956 \mathrm{E}-01-0,99948659 \mathrm{E}+00$

beta $4 \quad 0,15313523 \mathrm{E}-01 \quad 0,11271944 \mathrm{E}+00 \quad 0,13585521 \mathrm{E}+00$

beta $5 \quad 0,15702025 \mathrm{E}-01 \quad 0,26614150 \mathrm{E}-01 \quad 0,58998784 \mathrm{E}+00$

beta $6 \quad 0,75545596 \mathrm{E}+00 \quad 0,11800164 \mathrm{E}+00 \quad 0,64020803 \mathrm{E}+01$

beta $7 \quad-0,98733942 \mathrm{E}-02 \quad 0,11872762 \mathrm{E}-01-0,83160042 \mathrm{E}+00$

beta $8 \quad 0,25786063 \mathrm{E}-01 \quad 0,13007213 \mathrm{E}+00 \quad 0,19824433 \mathrm{E}+00$

delta $0 \quad-0,28791970 \mathrm{E}+00 \quad 0,11304909 \mathrm{E}+01-0,25468555 \mathrm{E}+00$

delta $1-0,94066512 \mathrm{E}+01 \quad 0,37803547 \mathrm{E}+01-0,24882986 \mathrm{E}+01$

delta $2 \quad-0,18990350 \mathrm{E}-01 \quad 0,11623636 \mathrm{E}+00-0,16337702 \mathrm{E}+00$ 
delta $3 \quad 0,38281230 \mathrm{E}+00 \quad 0,23415682 \mathrm{E}+00 \quad 0,16348543 \mathrm{E}+01$

delta $4 \quad-0,37857447 \mathrm{E}+00 \quad 0,46363929 \mathrm{E}+00-0,81652801 \mathrm{E}+00$

delta $5 \quad 0,10765817 \mathrm{E}+00 \quad 0,17149785 \mathrm{E}+00 \quad 0,62775233 \mathrm{E}+00$

delta $6 \quad-0,10641799 \mathrm{E}+01 \quad 0,57690999 \mathrm{E}+00-0,18446203 \mathrm{E}+01$

delta $7 \quad 0,46394952 \mathrm{E}+00 \quad 0,75000251 \mathrm{E}+00 \quad 0,61859728 \mathrm{E}+00$

delta $8 \quad 0,20576340 \mathrm{E}+00 \quad 0,52096200 \mathrm{E}+00 \quad 0,39496815 \mathrm{E}+00$

delta $9 \quad 0,36297724 \mathrm{E}+01 \quad 0,23688150 \mathrm{E}+01 \quad 0,15323157 \mathrm{E}+01$

sigma-squared $0,86764774 \mathrm{E}+00 \quad 0,26650109 \mathrm{E}+00 \quad 0,32557005 \mathrm{E}+01$

gamma $\quad 0,95494932 \mathrm{E}+00 \quad 0,20562378 \mathrm{E}-01 \quad 0,46441580 \mathrm{E}+02$

$\log$ likelihood function $=-0,44627863 \mathrm{E}+02$

LR test of the one-sided error $=0,52879217 \mathrm{E}+02$

with number of restrictions $=*$

[note that this statistic has a mixed chi-square distribution]

number of iterations $=31$

(maximum number of iterations set at : 500)

number of cross-sections $=117$

number of time periods $=\quad 1$

total number of observations $=117$

technical efficiency estimates :

$\begin{array}{ccc}\text { firm } & \text { year } & \text { eff,-est, } \\ & & \\ 1 & 1 & 0,74233094 \mathrm{E}+00 \\ 2 & 1 & 0,81327535 \mathrm{E}+00 \\ 3 & 1 & 0,88118056 \mathrm{E}+00 \\ 4 & 1 & 0,82389612 \mathrm{E}+00 \\ 5 & 1 & 0,76309408 \mathrm{E}+00 \\ 6 & 1 & 0,78975582 \mathrm{E}+00 \\ 7 & 1 & 0,83138081 \mathrm{E}+00 \\ 8 & 1 & 0,25452874 \mathrm{E}+00 \\ 9 & 1 & 0,79648821 \mathrm{E}+00 \\ 10 & 1 & 0,84185019 \mathrm{E}+00 \\ 11 & 1 & 0,58386318 \mathrm{E}+00 \\ 12 & 1 & 0,84949642 \mathrm{E}+00 \\ 13 & 1 & 0,89306959 \mathrm{E}+00\end{array}$




$\begin{array}{lll}14 & 1 & 0,92282668 \mathrm{E}+00 \\ 15 & 1 & 0,66762688 \mathrm{E}+00 \\ 16 & 1 & 0,84860908 \mathrm{E}+00 \\ 17 & 1 & 0,36749291 \mathrm{E}+00 \\ 18 & 1 & 0,70186304 \mathrm{E}+00 \\ 19 & 1 & 0,89665021 \mathrm{E}+00 \\ 20 & 1 & 0,85173041 \mathrm{E}+00 \\ 21 & 1 & 0,78513173 \mathrm{E}+00 \\ 22 & 1 & 0,45709871 \mathrm{E}-01 \\ 23 & 1 & 0,59079056 \mathrm{E}+00 \\ 24 & 1 & 0,87236068 \mathrm{E}+00 \\ 25 & 1 & 0,81204177 \mathrm{E}+00 \\ 26 & 1 & 0,25719959 \mathrm{E}+00 \\ 27 & 1 & 0,74421895 \mathrm{E}+00 \\ 28 & 1 & 0,72216974 \mathrm{E}+00 \\ 29 & 1 & 0,89597530 \mathrm{E}+00 \\ 30 & 1 & 0,84234643 \mathrm{E}+00 \\ 31 & 1 & 0,93437602 \mathrm{E}+00 \\ 32 & 1 & 0,77300788 \mathrm{E}+00 \\ 33 & 1 & 0,86838588 \mathrm{E}+00 \\ 34 & 1 & 0,69686554 \mathrm{E}+00 \\ 35 & 1 & 0,95008795 \mathrm{E}+00 \\ 36 & 1 & 0,73866647 \mathrm{E}+00 \\ 37 & 1 & 0,77939801 \mathrm{E}+00 \\ 38 & 1 & 0,75998829 \mathrm{E}+00 \\ 39 & 1 & 0,94388355 \mathrm{E}+00 \\ 40 & 1 & 0,64881104 \mathrm{E}+00 \\ 41 & 1 & 0,76675494 \mathrm{E}+00 \\ 42 & 1 & 0,86661020 \mathrm{E}+00 \\ 43 & 1 & 0,87698642 \mathrm{E}+00 \\ 44 & 1 & 0,77437636 \mathrm{E}+00 \\ 45 & 1 & 0,78921433 \mathrm{E}+00 \\ 46 & 1 & 0,68851651 \mathrm{E}+00 \\ 47 & 1 & 0,28488967 \mathrm{E}+00 \\ 48 & 1 & 0,43260854 \mathrm{E}+00 \\ 49 & 1 & 0,43617540 \mathrm{E}+00 \\ 50 & 1 & 0,63263987 \mathrm{E}+00 \\ 51 & 1 & 0,58727642 \mathrm{E}+00 \\ 52 & 1 & 0,73177139 \mathrm{E}+00 \\ 53 & 1 & 0,41351899 \mathrm{E}+00 \\ 54 & 1 & 0,69562871 \mathrm{E}+00 \\ 55 & 1 & 0,37459690 \mathrm{E}+00 \\ 56 & 1 & 0,77844321 \mathrm{E}+00 \\ 57 & 1 & 0,79932088 \mathrm{E}+00 \\ 58 & 1 & 0,83120463 \mathrm{E}+00\end{array}$




$\begin{array}{lll}59 & 1 & 0,54621791 \mathrm{E}+00 \\ 60 & 1 & 0,93381160 \mathrm{E}+00 \\ 61 & 1 & 0,65709065 \mathrm{E}+00 \\ 62 & 1 & 0,93570205 \mathrm{E}+00 \\ 63 & 1 & 0,91670584 \mathrm{E}+00 \\ 64 & 1 & 0,70479994 \mathrm{E}+00 \\ 65 & 1 & 0,76790114 \mathrm{E}+00 \\ 66 & 1 & 0,71275614 \mathrm{E}+00 \\ 67 & 1 & 0,79494397 \mathrm{E}+00 \\ 68 & 1 & 0,70237824 \mathrm{E}+00 \\ 69 & 1 & 0,84517065 \mathrm{E}+00 \\ 70 & 1 & 0,57954908 \mathrm{E}+00 \\ 71 & 1 & 0,49396794 \mathrm{E}+00 \\ 72 & 1 & 0,92593739 \mathrm{E}+00 \\ 73 & 1 & 0,90161488 \mathrm{E}+00 \\ 74 & 1 & 0,83083111 \mathrm{E}+00 \\ 75 & 1 & 0,79776245 \mathrm{E}+00 \\ 76 & 1 & 0,83468427 \mathrm{E}+00 \\ 77 & 1 & 0,88851533 \mathrm{E}+00 \\ 78 & 1 & 0,81419732 \mathrm{E}+00 \\ 79 & 1 & 0,86156892 \mathrm{E}+00 \\ 80 & 1 & 0,74781930 \mathrm{E}+00 \\ 81 & 1 & 0,78719127 \mathrm{E}+00 \\ 82 & 1 & 0,29288960 \mathrm{E}+00 \\ 83 & 1 & 0,87584367 \mathrm{E}+00 \\ 84 & 1 & 0,42756787 \mathrm{E}+00 \\ 85 & 1 & 0,67362082 \mathrm{E}+00 \\ 86 & 1 & 0,45700165 \mathrm{E}+00 \\ 87 & 1 & 0,51687209 \mathrm{E}+00 \\ 88 & 1 & 0,46936451 \mathrm{E}+00 \\ 89 & 1 & 0,79512517 \mathrm{E}+00 \\ 90 & 1 & 0,67190097 \mathrm{E}+00 \\ 91 & 1 & 0,79858339 \mathrm{E}+00 \\ 92 & 1 & 0,76538256 \mathrm{E}+00 \\ 93 & 1 & 0,52519814 \mathrm{E}+00 \\ 94 & 1 & 0,79933868 \mathrm{E}+00 \\ 95 & 1 & 0,68552269 \mathrm{E}+00 \\ 96 & 1 & 0,80753885 \mathrm{E}+00 \\ 97 & 1 & 0,80043835 \mathrm{E}+00 \\ 98 & 1 & 0,89098847 \mathrm{E}+00 \\ 99 & 1 & 0,90648466 \mathrm{E}+00 \\ 100 & 1 & 0,44240910 \mathrm{E}+00 \\ 101 & 1 & 0,74665687 \mathrm{E}+00 \\ 102 & 1 & 0,83414135 \mathrm{E}+00 \\ 103 & 1 & 0,88486363 \mathrm{E}+00\end{array}$




$\begin{array}{llll}104 & 1 & 0,66813065 \mathrm{E}+00 \\ 105 & 1 & 0,83706806 \mathrm{E}+00 \\ 106 & 1 & 0,89743801 \mathrm{E}+00 \\ 107 & 1 & 0,84585378 \mathrm{E}+00 \\ 108 & 1 & 0,89531690 \mathrm{E}+00 \\ 109 & 1 & 0,89311178 \mathrm{E}+00 \\ 110 & 1 & 0,86934923 \mathrm{E}+00 \\ 111 & 1 & 0,84194312 \mathrm{E}+00 \\ 112 & 1 & 0,85812392 \mathrm{E}+00 \\ 113 & 1 & 0,91919235 \mathrm{E}+00 \\ 114 & 1 & 0,83766498 \mathrm{E}+00 \\ 115 & 1 & 0,89643118 \mathrm{E}+00 \\ 116 & 1 & 0,62169012 \mathrm{E}+00 \\ 117 & 1 & 0,81235274 \mathrm{E}+00 \\ & & \end{array}$


APÊNDICE 3 - Coeficientes estimados para a região Centro-Oeste.

\section{REGIÃO CENTRO-OESTE}

pi Lucro

B1 Preço da eletricidade

B2 Preço do trabalho contratado

B3 Preço da forração

B4 Preço Carregamento

B5 Preço do aquecimento

B6 Área ocupada

B7 Trabalho familiar

B8 Capital

D1 Conversão alimentar

D2 Gastos com mitigação ambiental

D3 Concentração animal na fazenda

D4 Escala de produção

D5 Experiência na atividade

D6 Escolaridade

D7 Idade do gerente

D8 Possui atividade fora propriedade

D9 Mora na propriedade
$\mathrm{R} \$ / \mathrm{Pr}$

$\mathrm{R} \$ / \mathrm{KwH} / \mathrm{Pr}$

$\mathrm{R} \$ /$ horas/Pr

$\mathrm{R} \$ / \mathrm{t} / \mathrm{Pr}$

$\mathrm{R} \$ /$ frango/Pr

$\mathrm{R} \$ / \mathrm{kcal} / \mathrm{Pr}$

$\mathrm{M}^{2}$

Horas

$\mathrm{R} \$$

$\mathrm{kg}$ ração/kg animal vivo

$\mathrm{R} \$$

Frango/ha

Frango

Anos

$\mathrm{E} 1<3=0 ; 1$

Anos

Dummy $0=$ Não, $1=$ Sim

Dummy $0=$ Não, $1=$ Sim

Output from the program FRONTIER (Version 4,1c)

Tech, Eff, Effects Frontier (see B\&C 1993)

The model is a production function

The dependent variable is logged

the ols estimates are :

coefficient standard-error t-ratio

beta $0 \quad 0,29652748 \mathrm{E}+01 \quad 0,11116169 \mathrm{E}+01 \quad 0,26675332 \mathrm{E}+01$

beta $1-0,16722236 \mathrm{E}+00 \quad 0,26466977 \mathrm{E}+00-0,63181512 \mathrm{E}+00$

beta $2-0,34774653 \mathrm{E}-02 \quad 0,11662249 \mathrm{E}-01-0,29818137 \mathrm{E}+00$

beta $3 \quad 0,20789147 \mathrm{E}-01 \quad 0,65157575 \mathrm{E}-01 \quad 0,31905955 \mathrm{E}+00$

beta $4-0,18946356 \mathrm{E}+00 \quad 0,28717680 \mathrm{E}+00-0,65974536 \mathrm{E}+00$

beta $5 \quad-0,11481786 \mathrm{E}+00 \quad 0,38691199 \mathrm{E}-01-0,29675448 \mathrm{E}+01$

beta $6 \quad 0,58239769 \mathrm{E}+00 \quad 0,20674755 \mathrm{E}+00 \quad 0,28169509 \mathrm{E}+01$

beta $7 \quad 0,24582292 \mathrm{E}-01 \quad 0,10112041 \mathrm{E}-01 \quad 0,24309921 \mathrm{E}+01$

beta $8 \quad 0,39303361 \mathrm{E}+00 \quad 0,21465423 \mathrm{E}+00 \quad 0,18310080 \mathrm{E}+01$

sigma-squared $0,13738547 \mathrm{E}+00$ 
$\log$ likelihood function $=-0,30632678 \mathrm{E}+02$

the estimates after the grid search were :

$\begin{array}{lc}\text { beta } 0 & 0,33319667 \mathrm{E}+01 \\ \text { beta 1 } & -0,16722236 \mathrm{E}+00 \\ \text { beta 2 } & -0,34774653 \mathrm{E}-02 \\ \text { beta 3 } & 0,20789147 \mathrm{E}-01 \\ \text { beta } 4 & -0,18946356 \mathrm{E}+00 \\ \text { beta } 5 & -0,11481786 \mathrm{E}+00 \\ \text { beta 6 } & 0,58239769 \mathrm{E}+00 \\ \text { beta 7 } & 0,24582292 \mathrm{E}-01 \\ \text { beta } 8 & 0,39303361 \mathrm{E}+00 \\ \text { delta } 0 & 0,00000000 \mathrm{E}+00 \\ \text { delta 1 } & 0,00000000 \mathrm{E}+00 \\ \text { delta 2 } & 0,00000000 \mathrm{E}+00 \\ \text { delta 3 } & 0,00000000 \mathrm{E}+00 \\ \text { delta 4 } & 0,00000000 \mathrm{E}+00 \\ \text { delta 5 } & 0,00000000 \mathrm{E}+00 \\ \text { delta 6 } & 0,00000000 \mathrm{E}+00 \\ \text { delta 7 } & 0,00000000 \mathrm{E}+00 \\ \text { delta } 8 & 0,00000000 \mathrm{E}+00 \\ \text { delta } 9 & 0,00000000 \mathrm{E}+00\end{array}$

sigma-squared $0,25695118 \mathrm{E}+00$

gamma $\quad 0,82200000 \mathrm{E}+00$

the final mle estimates are :

coefficient standard-error t-ratio

beta $0 \quad 0,45819108 \mathrm{E}+01 \quad 0,10352172 \mathrm{E}+01 \quad 0,44260380 \mathrm{E}+01$

beta $1-0,71341936 \mathrm{E}-01 \quad 0,22720009 \mathrm{E}+00-0,31400488 \mathrm{E}+00$

beta $2 \quad-0,35733037 \mathrm{E}-02 \quad 0,11469787 \mathrm{E}-01-0,31154055 \mathrm{E}+00$

beta $3 \quad 0,50204959 \mathrm{E}-01 \quad 0,50416863 \mathrm{E}-01 \quad 0,99579698 \mathrm{E}+00$

beta $4 \quad 0,61143273 \mathrm{E}-02 \quad 0,27043645 \mathrm{E}+00 \quad 0,22609109 \mathrm{E}-01$

beta $5 \quad-0,31475285 \mathrm{E}-01 \quad 0,33185495 \mathrm{E}-01-0,94846515 \mathrm{E}+00$

beta $6 \quad 0,27178933 \mathrm{E}+00 \quad 0,18341369 \mathrm{E}+00 \quad 0,14818377 \mathrm{E}+01$

beta $7 \quad 0,18149106 \mathrm{E}-01 \quad 0,84508990 \mathrm{E}-02 \quad 0,21475947 \mathrm{E}+01$

beta $8 \quad 0,56350003 \mathrm{E}+00 \quad 0,17742980 \mathrm{E}+00 \quad 0,31759041 \mathrm{E}+01$

delta $0 \quad-0,31792527 \mathrm{E}+00 \quad 0,14160294 \mathrm{E}+01-0,22451884 \mathrm{E}+00$

delta $1 \quad 0,57623634 \mathrm{E}+01 \quad 0,43423080 \mathrm{E}+01 \quad 0,13270278 \mathrm{E}+01$

delta $2 \quad 0,39087393 \mathrm{E}-01 \quad 0,63395114 \mathrm{E}-01 \quad 0,61656791 \mathrm{E}+00$

delta $3 \quad-0,43438013 \mathrm{E}+00 \quad 0,34835502 \mathrm{E}+00-0,12469467 \mathrm{E}+01$ 
delta $4 \quad-0,74449594 \mathrm{E}+00 \quad 0,49261516 \mathrm{E}+00-0,15113135 \mathrm{E}+01$

delta $5 \quad-0,40010076 \mathrm{E}+00 \quad 0,64240662 \mathrm{E}+00-0,62281544 \mathrm{E}+00$

delta $6 \quad 0,11621743 \mathrm{E}+01 \quad 0,72016063 \mathrm{E}+00 \quad 0,16137709 \mathrm{E}+01$

delta $7 \quad 0,16353924 \mathrm{E}+01 \quad 0,13825443 \mathrm{E}+01 \quad 0,11828860 \mathrm{E}+01$

delta $8 \quad-0,24552655 \mathrm{E}+01 \quad 0,17408418 \mathrm{E}+01-0,14103898 \mathrm{E}+01$

delta $9 \quad 0,21596154 \mathrm{E}+00 \quad 0,34941230 \mathrm{E}+00 \quad 0,61807080 \mathrm{E}+00$

sigma-squared $0,30366551 \mathrm{E}+00 \quad 0,12448336 \mathrm{E}+00 \quad 0,24394064 \mathrm{E}+01$

gamma $\quad 0,86643350 \mathrm{E}+00 \quad 0,56232373 \mathrm{E}-01 \quad 0,15408091 \mathrm{E}+02$

$\log$ likelihood function $=-0,12232376 \mathrm{E}+02$

LR test of the one-sided error $=0,36800603 \mathrm{E}+02$

with number of restrictions $=*$

[note that this statistic has a mixed chi-square distribution]

number of iterations $=36$

(maximum number of iterations set at : 500 )

number of cross-sections $=83$

number of time periods $=\quad 1$

total number of observations $=83$

technical efficiency estimates :

$\begin{array}{ccc}\text { firm } & \text { year } & \text { eff,-est, } \\ & & \\ 1 & 1 & 0,93354432 \mathrm{E}+00 \\ 2 & 1 & 0,89094484 \mathrm{E}+00 \\ 3 & 1 & 0,86176896 \mathrm{E}+00 \\ 4 & 1 & 0,87677889 \mathrm{E}+00 \\ 5 & 1 & 0,88997952 \mathrm{E}+00 \\ 6 & 1 & 0,89389762 \mathrm{E}+00 \\ 7 & 1 & 0,80783304 \mathrm{E}+00 \\ 8 & 1 & 0,93026875 \mathrm{E}+00 \\ 9 & 1 & 0,84466780 \mathrm{E}+00 \\ 10 & 1 & 0,32594708 \mathrm{E}+00 \\ 11 & 1 & 0,90583890 \mathrm{E}+00 \\ 12 & 1 & 0,60925111 \mathrm{E}+00 \\ 13 & 1 & 0,91885117 \mathrm{E}+00 \\ 14 & 1 & 0,90515351 \mathrm{E}+00 \\ 15 & 1 & 0,85383790 \mathrm{E}+00 \\ 16 & 1 & 0,85844368 \mathrm{E}+00\end{array}$




$\begin{array}{lll}17 & 1 & 0,89390198 \mathrm{E}+00 \\ 18 & 1 & 0,90277760 \mathrm{E}+00 \\ 19 & 1 & 0,90689402 \mathrm{E}+00 \\ 20 & 1 & 0,29789654 \mathrm{E}+00 \\ 21 & 1 & 0,69603030 \mathrm{E}+00 \\ 22 & 1 & 0,62487880 \mathrm{E}+00 \\ 23 & 1 & 0,93915218 \mathrm{E}+00 \\ 24 & 1 & 0,92898394 \mathrm{E}+00 \\ 25 & 1 & 0,92034725 \mathrm{E}+00 \\ 26 & 1 & 0,91594158 \mathrm{E}+00 \\ 27 & 1 & 0,91714804 \mathrm{E}+00 \\ 28 & 1 & 0,61148239 \mathrm{E}+00 \\ 29 & 1 & 0,91046676 \mathrm{E}+00 \\ 30 & 1 & 0,81035806 \mathrm{E}+00 \\ 31 & 1 & 0,76687775 \mathrm{E}+00 \\ 32 & 1 & 0,43248060 \mathrm{E}+00 \\ 33 & 1 & 0,90859147 \mathrm{E}+00 \\ 34 & 1 & 0,88178359 \mathrm{E}+00 \\ 35 & 1 & 0,41912939 \mathrm{E}+00 \\ 36 & 1 & 0,82673987 \mathrm{E}+00 \\ 37 & 1 & 0,87621777 \mathrm{E}+00 \\ 38 & 1 & 0,84418738 \mathrm{E}+00 \\ 39 & 1 & 0,53752357 \mathrm{E}+00 \\ 40 & 1 & 0,81131319 \mathrm{E}+00 \\ 41 & 1 & 0,65874167 \mathrm{E}+00 \\ 42 & 1 & 0,44645855 \mathrm{E}+00 \\ 43 & 1 & 0,78018309 \mathrm{E}+00 \\ 44 & 1 & 0,92340378 \mathrm{E}+00 \\ 45 & 1 & 0,90180218 \mathrm{E}+00 \\ 46 & 1 & 0,82156425 \mathrm{E}+00 \\ 47 & 1 & 0,95173408 \mathrm{E}+00 \\ 48 & 1 & 0,91746317 \mathrm{E}+00 \\ 49 & 1 & 0,79181294 \mathrm{E}+00 \\ 50 & 1 & 0,86869729 \mathrm{E}+00 \\ 51 & 1 & 0,94082140 \mathrm{E}+00 \\ 52 & 1 & 0,89929255 \mathrm{E}+00 \\ 53 & 1 & 0,93131873 \mathrm{E}+00 \\ 54 & 1 & 0,80709625 \mathrm{E}+00 \\ 55 & 1 & 0,70482247 \mathrm{E}+00 \\ 56 & 1 & 0,25399668 \mathrm{E}+00 \\ 57 & 1 & 0,80846343 \mathrm{E}+00 \\ 58 & 1 & 0,49929379 \mathrm{E}+00 \\ 59 & 1 & 0,89128440 \mathrm{E}+00 \\ 60 & 1 & 0,80949192 \mathrm{E}+00 \\ 61 & 1 & 0,91221209 \mathrm{E}+00\end{array}$




$\begin{array}{lll}62 & 1 & 0,92766340 \mathrm{E}+00 \\ 63 & 1 & 0,95774544 \mathrm{E}+00 \\ 64 & 1 & 0,61220669 \mathrm{E}+00 \\ 65 & 1 & 0,82583699 \mathrm{E}+00 \\ 66 & 1 & 0,95204288 \mathrm{E}+00 \\ 67 & 1 & 0,90093904 \mathrm{E}+00 \\ 68 & 1 & 0,92961593 \mathrm{E}+00 \\ 69 & 1 & 0,89084128 \mathrm{E}+00 \\ 70 & 1 & 0,95252742 \mathrm{E}+00 \\ 71 & 1 & 0,93032898 \mathrm{E}+00 \\ 72 & 1 & 0,24805339 \mathrm{E}+00 \\ 73 & 1 & 0,94617374 \mathrm{E}+00 \\ 74 & 1 & 0,83505181 \mathrm{E}+00 \\ 75 & 1 & 0,95077787 \mathrm{E}+00 \\ 76 & 1 & 0,79454141 \mathrm{E}+00 \\ 77 & 1 & 0,91479834 \mathrm{E}+00 \\ 78 & 1 & 0,90193728 \mathrm{E}+00 \\ 79 & 1 & 0,90547464 \mathrm{E}+00 \\ 80 & 1 & 0,90056106 \mathrm{E}+00 \\ 81 & 1 & 0,72004815 \mathrm{E}+00 \\ 82 & 1 & 0,93832158 \mathrm{E}+00 \\ 83 & 1 & 0,82813570 \mathrm{E}+00\end{array}$

mean efficiency $=0,80929746 \mathrm{E}+00$ 
APÊNDICE 4 - Coeficientes estimados para o Brasil.

BRASIL N=200

pi Lucro

$\mathrm{R} \$ / \mathrm{Pr}$

B1 Preço da eletricidade

$\mathrm{R} \$ / \mathrm{KwH} / \mathrm{Pr}$

B2 Preço do trabalho contratado

$\mathrm{R} \$ /$ horas/Pr

B3 Preço da forração

$\mathrm{R} \$ / \mathrm{t} / \mathrm{Pr}$

B4 Preço Carregamento

$\mathrm{R} \$ /$ frango/Pr

B5 Preço do aquecimento

B6 Área ocupada

$\mathrm{R} \$ / \mathrm{kcal} / \mathrm{Pr}$

B7 Trabalho familiar

$\mathrm{M}^{2}$

Horas

B8 Capital

$\mathrm{R} \$$

D1 Conversão alimentar

D2 Gastos com mitigação ambiental

$\mathrm{kg}$ ração/kg frango vivo

$\mathrm{R} \$$

Frango/ha

Frango

D4 Escala de produção

D5 Experiência na atividade

Anos

D6 Escolaridade

E1<3

D7 Idade do gerente

D8 Possui atividade fora propriedade

Anos

D9 Mora na propriedade

Dummy $0=$ Não, $1=$ Sim

Dummy $0=$ Não, $1=$ Sim

D10 Dummy

Dummy $1=$ Sul, $0=$ outros

Output from the program FRONTIER (Version 4,1c)

instruction file $=$ teste, ins

data file $=$ teste, $\mathrm{dta}$

Tech, Eff, Effects Frontier (see B\&C 1993)

The model is a production function

The dependent variable is logged

the ols estimates are :

coefficient standard-error t-ratio

beta $0 \quad 0,33164326 \mathrm{E}+01 \quad 0,51338562 \mathrm{E}+00 \quad 0,64599249 \mathrm{E}+01$

beta $1-0,27683279 \mathrm{E}+00 \quad 0,16637081 \mathrm{E}+00-0,16639505 \mathrm{E}+01$

beta $2 \quad-0,48691447 \mathrm{E}-02 \quad 0,10006482 \mathrm{E}-01-0,48659905 \mathrm{E}+00$

beta $3 \quad 0,13720485 \mathrm{E}+00 \quad 0,46094666 \mathrm{E}-01 \quad 0,29765885 \mathrm{E}+01$

beta $4 \quad 0,98774996 \mathrm{E}-01 \quad 0,11675108 \mathrm{E}+00 \quad 0,84603069 \mathrm{E}+00$

beta $5 \quad-0,53024080 \mathrm{E}-01 \quad 0,26340733 \mathrm{E}-01-0,20130070 \mathrm{E}+01$

beta $6 \quad 0,51793360 \mathrm{E}+00 \quad 0,11324675 \mathrm{E}+00 \quad 0,45734963 \mathrm{E}+01$

beta $7 \quad 0,64840108 \mathrm{E}-02 \quad 0,97443327 \mathrm{E}-02 \quad 0,66541353 \mathrm{E}+00$ 
beta $8 \quad 0,39981265 \mathrm{E}+00 \quad 0,11776474 \mathrm{E}+00 \quad 0,33950115 \mathrm{E}+01$ sigma-squared $0,19707856 \mathrm{E}+00$

$\log$ likelihood function $=-0,11676802 \mathrm{E}+03$

the estimates after the grid search were :
beta $0 \quad 0,38092607 \mathrm{E}+01$
beta $1-0,27683279 \mathrm{E}+00$
beta $2 \quad-0,48691447 \mathrm{E}-02$
beta $3 \quad 0,13720485 \mathrm{E}+00$
beta $4 \quad 0,98774996 \mathrm{E}-01$
beta $5 \quad-0,53024080 \mathrm{E}-01$
beta $6 \quad 0,51793360 \mathrm{E}+00$
beta $7 \quad 0,64840108 \mathrm{E}-02$
beta $8 \quad 0,39981265 \mathrm{E}+00$
delta $0 \quad 0,00000000 \mathrm{E}+00$
delta $1 \quad 0,00000000 \mathrm{E}+00$
delta $2 \quad 0,00000000 \mathrm{E}+00$
delta $3 \quad 0,00000000 \mathrm{E}+00$
delta $4 \quad 0,00000000 \mathrm{E}+00$
delta $5 \quad 0,00000000 \mathrm{E}+00$
delta $6 \quad 0,00000000 \mathrm{E}+00$
delta $7 \quad 0,00000000 \mathrm{E}+00$
delta $8 \quad 0,00000000 \mathrm{E}+00$
delta $9 \quad 0,00000000 \mathrm{E}+00$
delta10 0,00000000E +00
sigma-squared $0,43108956 \mathrm{E}+00$
gamma $\quad 0,88500000 \mathrm{E}+00$

the final mle estimates are :

coefficient standard-error t-ratio

beta $0 \quad 0,37759076 \mathrm{E}+01 \quad 0,51343944 \mathrm{E}+00 \quad 0,73541439 \mathrm{E}+01$

beta $1-0,21044166 \mathrm{E}+00 \quad 0,11464769 \mathrm{E}+00-0,18355508 \mathrm{E}+01$

beta $2 \quad-0,49919754 \mathrm{E}-02 \quad 0,70743071 \mathrm{E}-02-0,70564867 \mathrm{E}+00$

beta $3 \quad 0,10949321 \mathrm{E}+00 \quad 0,35682549 \mathrm{E}-01 \quad 0,30685368 \mathrm{E}+01$

beta $4 \quad 0,41742778 \mathrm{E}-01 \quad 0,10021364 \mathrm{E}+00 \quad 0,41653788 \mathrm{E}+00$

beta $5 \quad-0,12668802 \mathrm{E}-01 \quad 0,19989201 \mathrm{E}-01-0,63378230 \mathrm{E}+00$

beta $6 \quad 0,63635880 \mathrm{E}+00 \quad 0,10483013 \mathrm{E}+00 \quad 0,60703809 \mathrm{E}+01$

beta $7 \quad 0,96857555 \mathrm{E}-02 \quad 0,66355191 \mathrm{E}-02 \quad 0,14596832 \mathrm{E}+01$

beta $8 \quad 0,25946432 \mathrm{E}+00 \quad 0,97480025 \mathrm{E}-01 \quad 0,26617178 \mathrm{E}+01$

delta $0 \quad 0,58629164 \mathrm{E}+01 \quad 0,58246649 \mathrm{E}+01 \quad 0,10065672 \mathrm{E}+01$ 
delta $1-0,16980725 \mathrm{E}+02 \quad 0,92633752 \mathrm{E}+01-0,18331034 \mathrm{E}+01$

delta $2 \quad 0,12103428 \mathrm{E}-01 \quad 0,53358363 \mathrm{E}-01 \quad 0,22683282 \mathrm{E}+00$

delta $3-0,50502325 \mathrm{E}+00 \quad 0,31271600 \mathrm{E}+00-0,16149581 \mathrm{E}+01$

delta $4 \quad-0,26111627 \mathrm{E}+00 \quad 0,39784684 \mathrm{E}+00-0,65632361 \mathrm{E}+00$

delta $5 \quad 0,30832682 \mathrm{E}+00 \quad 0,26103749 \mathrm{E}+00 \quad 0,11811591 \mathrm{E}+01$

delta $6 \quad 0,61258604 \mathrm{E}+00 \quad 0,42700258 \mathrm{E}+00 \quad 0,14346191 \mathrm{E}+01$

delta $7 \quad 0,76241435 \mathrm{E}+00 \quad 0,51728392 \mathrm{E}+00 \quad 0,14738799 \mathrm{E}+01$

delta $8 \quad-0,21878310 \mathrm{E}+01 \quad 0,13681110 \mathrm{E}+01-0,15991619 \mathrm{E}+01$

delta $9 \quad 0,12208505 \mathrm{E}+01 \quad 0,80769829 \mathrm{E}+00 \quad 0,15115179 \mathrm{E}+01$

delta10 $\quad 0,16606105 \mathrm{E}+01 \quad 0,83104127 \mathrm{E}+00 \quad 0,19982287 \mathrm{E}+01$

sigma-squared $0,19245436 \mathrm{E}+01 \quad 0,10571600 \mathrm{E}+01 \quad 0,18204847 \mathrm{E}+01$

gamma $\quad 0,97502352 \mathrm{E}+00 \quad 0,14989285 \mathrm{E}-01 \quad 0,65048035 \mathrm{E}+02$

$\log$ likelihood function $=-0,84248521 \mathrm{E}+02$

LR test of the one-sided error $=0,65039007 \mathrm{E}+02$

with number of restrictions $=*$

[note that this statistic has a mixed chi-square distribution]

number of iterations $=38$

(maximum number of iterations set at : 500 )

number of cross-sections $=200$

number of time periods $=\quad 1$

total number of observations $=200$

thus there are: 0 obsns not in the panel

technical efficiency estimates :

$\begin{array}{ccc}\text { firm } & \text { year } & \text { eff,-est, } \\ & & \\ 1 & 1 & 0,83034815 \mathrm{E}+00 \\ 2 & 1 & 0,84587230 \mathrm{E}+00 \\ 3 & 1 & 0,88924640 \mathrm{E}+00 \\ 4 & 1 & 0,81508802 \mathrm{E}+00 \\ 5 & 1 & 0,77184750 \mathrm{E}+00 \\ 6 & 1 & 0,77258465 \mathrm{E}+00 \\ 7 & 1 & 0,86742348 \mathrm{E}+00 \\ 8 & 1 & 0,28603591 \mathrm{E}+00 \\ 9 & 1 & 0,74245055 \mathrm{E}+00\end{array}$




$\begin{array}{lll}10 & 1 & 0,85865741 \mathrm{E}+00 \\ 11 & 1 & 0,61888178 \mathrm{E}+00 \\ 12 & 1 & 0,78234310 \mathrm{E}+00 \\ 13 & 1 & 0,88251912 \mathrm{E}+00 \\ 14 & 1 & 0,94124107 \mathrm{E}+00 \\ 15 & 1 & 0,67567455 \mathrm{E}+00 \\ 16 & 1 & 0,86216435 \mathrm{E}+00 \\ 17 & 1 & 0,40074531 \mathrm{E}+00 \\ 18 & 1 & 0,71960415 \mathrm{E}+00 \\ 19 & 1 & 0,88124564 \mathrm{E}+00 \\ 20 & 1 & 0,85997898 \mathrm{E}+00 \\ 21 & 1 & 0,81138481 \mathrm{E}+00 \\ 22 & 1 & 0,50536440 \mathrm{E}-01 \\ 23 & 1 & 0,71184321 \mathrm{E}+00 \\ 24 & 1 & 0,85910695 \mathrm{E}+00 \\ 25 & 1 & 0,80198286 \mathrm{E}+00 \\ 26 & 1 & 0,25729003 \mathrm{E}+00 \\ 27 & 1 & 0,80688228 \mathrm{E}+00 \\ 28 & 1 & 0,84457951 \mathrm{E}+00 \\ 29 & 1 & 0,88181028 \mathrm{E}+00 \\ 30 & 1 & 0,85299856 \mathrm{E}+00 \\ 31 & 1 & 0,89413995 \mathrm{E}+00 \\ 32 & 1 & 0,78121230 \mathrm{E}+00 \\ 33 & 1 & 0,82653768 \mathrm{E}+00 \\ 34 & 1 & 0,58359267 \mathrm{E}+00 \\ 35 & 1 & 0,94647289 \mathrm{E}+00 \\ 36 & 1 & 0,76640223 \mathrm{E}+00 \\ 37 & 1 & 0,70215069 \mathrm{E}+00 \\ 38 & 1 & 0,67880933 \mathrm{E}+00 \\ 39 & 1 & 0,91918207 \mathrm{E}+00 \\ 40 & 1 & 0,70821482 \mathrm{E}+00 \\ 41 & 1 & 0,74545079 \mathrm{E}+00 \\ 42 & 1 & 0,86798786 \mathrm{E}+00 \\ 43 & 1 & 0,84491042 \mathrm{E}+00 \\ 44 & 1 & 0,82891193 \mathrm{E}+00 \\ 45 & 1 & 0,66070894 \mathrm{E}+00 \\ 46 & 1 & 0,76828797 \mathrm{E}+00 \\ 47 & 1 & 0,27635345 \mathrm{E}+00 \\ 48 & 1 & 0,40109854 \mathrm{E}+00 \\ 49 & 1 & 0,39937443 \mathrm{E}+00 \\ 50 & 1 & 0,69822495 \mathrm{E}+00 \\ 51 & 1 & 0,63389699 \mathrm{E}+00 \\ 52 & 1 & 0,77557196 \mathrm{E}+00 \\ 53 & 1 & 0,44195630 \mathrm{E}+00 \\ 54 & 1 & 0,74574281 \mathrm{E}+00\end{array}$




$\begin{array}{lll}55 & 1 & 0,45827568 \mathrm{E}+00 \\ 56 & 1 & 0,72867620 \mathrm{E}+00 \\ 57 & 1 & 0,78882240 \mathrm{E}+00 \\ 58 & 1 & 0,77159515 \mathrm{E}+00 \\ 59 & 1 & 0,51650042 \mathrm{E}+00 \\ 60 & 1 & 0,90210360 \mathrm{E}+00 \\ 61 & 1 & 0,59417646 \mathrm{E}+00 \\ 62 & 1 & 0,89712859 \mathrm{E}+00 \\ 63 & 1 & 0,89548014 \mathrm{E}+00 \\ 64 & 1 & 0,57738001 \mathrm{E}+00 \\ 65 & 1 & 0,73616652 \mathrm{E}+00 \\ 66 & 1 & 0,59423068 \mathrm{E}+00 \\ 67 & 1 & 0,74819718 \mathrm{E}+00 \\ 68 & 1 & 0,60283514 \mathrm{E}+00 \\ 69 & 1 & 0,82711895 \mathrm{E}+00 \\ 70 & 1 & 0,55702876 \mathrm{E}+00 \\ 71 & 1 & 0,43443450 \mathrm{E}+00 \\ 72 & 1 & 0,91037224 \mathrm{E}+00 \\ 73 & 1 & 0,84744713 \mathrm{E}+00 \\ 74 & 1 & 0,74182271 \mathrm{E}+00 \\ 75 & 1 & 0,71610154 \mathrm{E}+00 \\ 76 & 1 & 0,79010702 \mathrm{E}+00 \\ 77 & 1 & 0,84640113 \mathrm{E}+00 \\ 78 & 1 & 0,79536315 \mathrm{E}+00 \\ 79 & 1 & 0,79595360 \mathrm{E}+00 \\ 80 & 1 & 0,58257776 \mathrm{E}+00 \\ 81 & 1 & 0,69583894 \mathrm{E}+00 \\ 82 & 1 & 0,29606896 \mathrm{E}+00 \\ 83 & 1 & 0,83889372 \mathrm{E}+00 \\ 84 & 1 & 0,39530968 \mathrm{E}+00 \\ 85 & 1 & 0,44034190 \mathrm{E}+00 \\ 86 & 1 & 0,39293901 \mathrm{E}+00 \\ 87 & 1 & 0,50074087 \mathrm{E}+00 \\ 88 & 1 & 0,44704037 \mathrm{E}+00 \\ 89 & 1 & 0,76922467 \mathrm{E}+00 \\ 90 & 1 & 0,50978173 \mathrm{E}+00 \\ 91 & 1 & 0,74688899 \mathrm{E}+00 \\ 92 & 1 & 0,70580414 \mathrm{E}+00 \\ 93 & 1 & 0,59600144 \mathrm{E}+00 \\ 94 & 1 & 0,73208025 \mathrm{E}+00 \\ 95 & 1 & 0,56592439 \mathrm{E}+00 \\ 96 & 1 & 0,77820913 \mathrm{E}+00 \\ 97 & 1 & 0,77344314 \mathrm{E}+00 \\ 98 & 1 & 0,86605552 \mathrm{E}+00 \\ 99 & 1 & 0,89820375 \mathrm{E}+00\end{array}$




$\begin{array}{lll}100 & 1 & 0,42044671 \mathrm{E}+00 \\ 101 & 1 & 0,66143096 \mathrm{E}+00 \\ 102 & 1 & 0,80092044 \mathrm{E}+00 \\ 103 & 1 & 0,87109381 \mathrm{E}+00 \\ 104 & 1 & 0,56985956 \mathrm{E}+00 \\ 105 & 1 & 0,77603103 \mathrm{E}+00 \\ 106 & 1 & 0,87462848 \mathrm{E}+00 \\ 107 & 1 & 0,80558668 \mathrm{E}+00 \\ 108 & 1 & 0,87040944 \mathrm{E}+00 \\ 109 & 1 & 0,81539035 \mathrm{E}+00 \\ 110 & 1 & 0,81941196 \mathrm{E}+00 \\ 111 & 1 & 0,76068908 \mathrm{E}+00 \\ 112 & 1 & 0,71752600 \mathrm{E}+00 \\ 113 & 1 & 0,86311490 \mathrm{E}+00 \\ 114 & 1 & 0,72674293 \mathrm{E}+00 \\ 115 & 1 & 0,76686954 \mathrm{E}+00 \\ 116 & 1 & 0,48512109 \mathrm{E}+00 \\ 117 & 1 & 0,70050537 \mathrm{E}+00 \\ 118 & 1 & 0,93185903 \mathrm{E}+00 \\ 119 & 1 & 0,74639509 \mathrm{E}+00 \\ 120 & 1 & 0,84343309 \mathrm{E}+00 \\ 121 & 1 & 0,88635816 \mathrm{E}+00 \\ 122 & 1 & 0,85640523 \mathrm{E}+00 \\ 123 & 1 & 0,88613547 \mathrm{E}+00 \\ 124 & 1 & 0,66140735 \mathrm{E}+00 \\ 125 & 1 & 0,83025552 \mathrm{E}+00 \\ 126 & 1 & 0,82726448 \mathrm{E}+00 \\ 127 & 1 & 0,34907745 \mathrm{E}+00 \\ 128 & 1 & 0,84192875 \mathrm{E}+00 \\ 129 & 1 & 0,59817417 \mathrm{E}+00 \\ 130 & 1 & 0,92182039 \mathrm{E}+00 \\ 131 & 1 & 0,88498092 \mathrm{E}+00 \\ 132 & 1 & 0,82781771 \mathrm{E}+00 \\ 133 & 1 & 0,88020025 \mathrm{E}+00 \\ 134 & 1 & 0,82342163 \mathrm{E}+00 \\ 135 & 1 & 0,91521527 \mathrm{E}+00 \\ 136 & 1 & 0,88298275 \mathrm{E}+00 \\ 137 & 1 & 0,23213096 \mathrm{E}+00 \\ 138 & 1 & 0,75879645 \mathrm{E}+00 \\ 139 & 1 & 0,55072402 \mathrm{E}+00 \\ 140 & 1 & 0,90723703 \mathrm{E}+00 \\ 141 & 1 & 0,87046947 \mathrm{E}+00 \\ 142 & 1 & 0,84469867 \mathrm{E}+00 \\ 143 & 1 & 0,88361877 \mathrm{E}+00 \\ 144 & 1 & 0,90858629 \mathrm{E}+00\end{array}$




$\begin{array}{lll}145 & 1 & 0,63094555 \mathrm{E}+00 \\ 146 & 1 & 0,86864426 \mathrm{E}+00 \\ 147 & 1 & 0,75692272 \mathrm{E}+00 \\ 148 & 1 & 0,83439105 \mathrm{E}+00 \\ 149 & 1 & 0,57816561 \mathrm{E}+00 \\ 150 & 1 & 0,87190561 \mathrm{E}+00 \\ 151 & 1 & 0,81100919 \mathrm{E}+00 \\ 152 & 1 & 0,54888264 \mathrm{E}+00 \\ 153 & 1 & 0,79744233 \mathrm{E}+00 \\ 154 & 1 & 0,85633489 \mathrm{E}+00 \\ 155 & 1 & 0,83195022 \mathrm{E}+00 \\ 156 & 1 & 0,68879662 \mathrm{E}+00 \\ 157 & 1 & 0,81473646 \mathrm{E}+00 \\ 158 & 1 & 0,74084099 \mathrm{E}+00 \\ 159 & 1 & 0,62328954 \mathrm{E}+00 \\ 160 & 1 & 0,81946213 \mathrm{E}+00 \\ 161 & 1 & 0,91375101 \mathrm{E}+00 \\ 162 & 1 & 0,89466918 \mathrm{E}+00 \\ 163 & 1 & 0,87302370 \mathrm{E}+00 \\ 164 & 1 & 0,92187916 \mathrm{E}+00 \\ 165 & 1 & 0,83895316 \mathrm{E}+00 \\ 166 & 1 & 0,75128245 \mathrm{E}+00 \\ 167 & 1 & 0,86276533 \mathrm{E}+00 \\ 168 & 1 & 0,88421363 \mathrm{E}+00 \\ 169 & 1 & 0,89642807 \mathrm{E}+00 \\ 170 & 1 & 0,91125162 \mathrm{E}+00 \\ 171 & 1 & 0,83914067 \mathrm{E}+00 \\ 172 & 1 & 0,65136196 \mathrm{E}+00 \\ 173 & 1 & 0,28046678 \mathrm{E}+00 \\ 174 & 1 & 0,86895334 \mathrm{E}+00 \\ 175 & 1 & 0,56760444 \mathrm{E}+00 \\ 176 & 1 & 0,87818284 \mathrm{E}+00 \\ 177 & 1 & 0,90721795 \mathrm{E}+00 \\ 178 & 1 & 0,81378443 \mathrm{E}+00 \\ 179 & 1 & 0,84239805 \mathrm{E}+00 \\ 180 & 1 & 0,92866185 \mathrm{E}+00 \\ 181 & 1 & 0,70153226 \mathrm{E}+00 \\ 182 & 1 & 0,86824472 \mathrm{E}+00 \\ 183 & 1 & 0,91567815 \mathrm{E}+00 \\ 184 & 1 & 0,89078055 \mathrm{E}+00 \\ 185 & 1 & 0,87443175 \mathrm{E}+00 \\ 186 & 1 & 0,83380373 \mathrm{E}+00 \\ 187 & 1 & 0,93310046 \mathrm{E}+00 \\ 188 & 1 & 0,88737543 \mathrm{E}+00 \\ 189 & 1 & 0,28186227 \mathrm{E}+00\end{array}$




$\begin{array}{ccr}190 & 1 & 0,93531157 \mathrm{E}+00 \\ 191 & 1 & 0,87917077 \mathrm{E}+00 \\ 192 & 1 & 0,89304289 \mathrm{E}+00 \\ 193 & 1 & 0,61743701 \mathrm{E}+00 \\ 194 & 1 & 0,91349509 \mathrm{E}+00 \\ 195 & 1 & 0,85296169 \mathrm{E}+00 \\ 196 & 1 & 0,86653062 \mathrm{E}+00 \\ 197 & 1 & 0,81678373 \mathrm{E}+00 \\ 198 & 1 & 0,74076695 \mathrm{E}+00 \\ 199 & 1 & 0,86844408 \mathrm{E}+00 \\ 200 & 1 & 0,79342082 \mathrm{E}+00 \\ \text { mean efficiency }= & 0,74551852 \mathrm{E}+00\end{array}$


APÊNDICE 5 - Coeficientes estimados para a região Centro-Oeste incluindo o estado de Minas Gerais.

\begin{tabular}{|c|c|c|c|c|}
\hline & Variáveis & Coeficientes & Erro Padrão & Teste $\mathrm{t}$ \\
\hline \multicolumn{5}{|c|}{ Fronteira estocástica } \\
\hline$\beta_{0}$ & Constante & 3,597 & 0,664 & $5,415 * * *$ \\
\hline$\beta_{1}$ & Preço da eletricidade & 0,148 & 0,202 & 0,733 \\
\hline$\beta_{2}$ & Preço do trabalho contratado & $-0,006$ & 0,009 & $-0,619$ \\
\hline$\beta_{3}$ & Preço da forração & 0,033 & 0,043 & 0,763 \\
\hline$\beta_{4}$ & Preço Carregamento & $-0,257$ & 0,187 & $-1,373$ \\
\hline$\beta_{5}$ & Preço do aquecimento & $-0,069$ & 0,028 & $-2,445 * *$ \\
\hline$\beta_{6}$ & Área ocupada & 0,234 & 0,177 & 1,325 \\
\hline$\beta_{7}$ & Trabalho familiar & 0,019 & 0,008 & $2,358 * *$ \\
\hline$\beta_{8}$ & Capital & 0,669 & 0,163 & $4,099 * * *$ \\
\hline \multicolumn{5}{|c|}{ Ineficiências } \\
\hline$\delta_{0}$ & Constante & 4,400 & 2,003 & $2,197 * *$ \\
\hline$\delta_{1}$ & Conversão alimentar & 6,708 & 2,391 & $2,806 * * *$ \\
\hline$\delta_{2}$ & Custo ambiental & $-0,045$ & 0,038 & $-1,194$ \\
\hline$\delta_{3}$ & Concentração Animal na fazenda & $-0,325$ & 0,172 & $-1,889 *$ \\
\hline$\delta_{4}$ & Escala de produção & $-1,585$ & 0,713 & $-2,223 * *$ \\
\hline$\delta_{5}$ & Experiência na atividade & 0,061 & 0,213 & 0,286 \\
\hline$\delta_{6}$ & Escolaridade & 2,127 & 1,073 & $1,983 * *$ \\
\hline$\delta_{7}$ & Idade do gerente & 1,822 & 1,390 & 1,311 \\
\hline$\delta_{8}$ & Atividade fora propriedade & $-4,249$ & 2,614 & $-1,626$ \\
\hline$\delta_{9}$ & Mora na propriedade & $-0,857$ & 0,476 & $-1,801 *$ \\
\hline$\sigma^{2}$ & Sigma quadrado & 1,085 & 0,478 & $2,267 * *$ \\
\hline$\gamma$ & Gama & 0,956 & 0,024 & $39,289 * * *$ \\
\hline
\end{tabular}

Fonte: Elaborado pelo autor.

* Significante a $10 \%$

**Significante a 5\%

***Significante a $1 \%$ 